\title{
Identification of a septin filament required for CNS myelin integrity
}

\author{
Dissertation \\ for the award of the degree \\ “Doctor rerum naturalium" (Dr. rer. nat) \\ Division of Mathematics and Natural Sciences \\ of the Georg-August-Universität Göttingen
}

\author{
submitted by \\ Julia Patzig \\ born in \\ Riesa, Germany
}


Prof. Klaus-Armin Nave Ph.D. (Reviewer)

Department of Neurogenetics,

Max-Planck-Institute of Experimental Medicine

Prof. Dr. Fred S. Wouters (Reviewer)

Department of Neuro- and Sensory Physiology, University of Göttingen

Dr. Judith Stegmüller (Reviewer)

Department of Cellular and Molecular Neurobiology,

Max-Planck-Institute of Experimental Medicine

Date of the oral examination: 04.04 .2013 


\section{Declaration}

I hereby declare that the $\mathrm{PhD}$ thesis entitled, "Identification of a septin filament required for CNS myelin integrity", has been written independently and with no other sources and aids than quoted.

Göttingen, 22.02.2013

Julia Patzig 


\section{Acknowledgments}

I want to thank Prof. Klaus-Armin Nave Ph.D. for giving me the opportunity to work in his department. It was a great experience to develop in a working atmosphere, in which it is encouraged to discuss own ideas at equal levels. I thank him a lot for sharing his scientific experience and knowledge.

I am sincerely grateful to Dr. Hauke Werner for his supervision. With his influence, I developed as a scientist and as a person. It was always great to discuss ideas and to exchange different opinions. I'm very thankful for his patience and support.

I would like to thank the members of my thesis committee, Prof. Dr. Fred S. Wouters and Dr. Judith Stegmüller. The discussions were very helpful for the work presented here.

I am deeply thankful to Torben Ruhwedel and Dr. Wiebke Möbius for teaching me the methods of electron microscopy. They were always very helpful and supported my experiments.

I thank Dr. Mišo Mitkovski for teaching me the art of confocal microscopy. With his technical and biological knowledge, he influenced my experimental planning and analysis.

I thank Benoit Barrette Ph.D. for teaching me the method of inducing experimental autoimmune encephalomyelitis.

I thank Dr. Stefan Tenzer for his collaboration. With him, it was possible to quantitatively analyze the proteins in our myelin samples.

I thank Prof. Nicole Schaeren-Wiemers Ph.D. and Koh-ichi Nagata, M.D., Ph.D. for the supply of antibodies for septin proteins.

I thank Dr. Sandra Göbbels, Dr. Wiebke Möbius, Dr. Gesine Saher, and Dr. Markus Schwab for many scientific and non-scientific discussions. They influenced my way of thinking a lot and it greatly helped me along the way.

I'm grateful for the excellent working atmosphere in the lab. I thank Katja Aschenbrenner, Ulrike Gerwig, Ramona Jung, Dr. Kathrin Kusch and Georg Wieser for a fun and helpful environment.

I thank Jennifer Barth, Ulrike Bode, Annette Fahrenholz and Ramona Jung for technical support in many ways.

During the time in the department of Neurogenetics, I had the pleasure to guide several intelligent and talented students through their first scientific work. I therefore thank Nicole Bartsch, Andrea Franz, Ann-Kristin Martens and Tadzio Wagner for their contributing effort.

I thank the animal caretakers for looking after my mice, especially Astrid Kanbach, Kerstin Claus and Marion Peine. Their work was an important basis for my experiments.

I want to thank Lothar Demel, Hans-Joachim Horn and Rolf Merker for all technical help regarding computer issues.

I'm very grateful for my wonderful family that has supported me all my life, and to friends, especially Victoria Claes and Philipp Miethe for their love and encouragement. 


\section{Content}

List of figures

Abbreviations _ 8

1. Abstract

2. Introduction

2.1. Cells of the nervous system ___ 12

2.2. Assembly and structural organization of myelin

2.3. Axonal pathology related to oligodendroglial dysfunction

2.4. Relevance of myelin thickness and integrity _ 16

2.5. Septins _ 16

2.6. Septin functions in post-mitotic mammalian cells

2.7. Inflammation in the central nervous system _ 19

2.8. Aim of the study _ 21

3. Material and Methods___ 22

3.1. Material _ـ 22

3.1.1. Kits and chemicals _ 22

3.1.2. Molecular biology __ 22

3.1.3. Protein biochemistry buffers __ 23

3.1.4. SDS PAGE and immunoblot__ 23

3.1.5. Solutions for Fixation __ 25

3.1.6. Immunohistochemistry and staining solutions __ 26

3.1.7. Electron microscopy __ 28

3.1.8. Antibodies _ 29

3.1.9. Oligonucleotides _ 31

3.1.10. Mouse lines _ 32

3.2. Methods_ 33

3.2.1. Animals__ 33

3.2.1.1. Generation of SEPT8 deficient mice___ 33

3.2.1.2. Genotyping of mice___ 33

3.2.2. Protein biochemical analysis _ 35

3.2.2.1. Sample preparation _ـ 35

3.2.2.2. Myelin purification method __ 35

3.2.2.3. Protein concentration measurement by the Lowry method ___ 36

3.2.2.4. Quantitative Mass Spectrometry _ 36

3.2.2.5. Separating Proteins using SDS Page ___ 36

3.2.2.6. Immunoblot___ 36

3.2.2.7. Immunodetection of blotted proteins__ 37

3.2.3. RNA isolation and analysis __ 37

3.2.3.1. RNA isolation ('RNeasy mini prep') __ 37

3.2.3.2. RNA measurement with Agilent 38

3.2.3.2. cDNA synthesis ___ 38

3.2.3.3. Quantitative real time PCR (qRT-PCR)__ 39

3.2.4. Histological analysis _ـ 39

3.2.4.1. Teased fiber preparation __ 39

3.2.4.2. Perfusion fixation of mouse tissue ___ 39 
3.2.4.3. Immunohistochemistry of cryosections _ $\quad 40$

3.2.4.4. Imaging of fluorescent stainings _ 40

3.2.4.5. Detection of $\beta$-galactosidase in tissue sections (X-gal staining) _ $\quad 40$

3.2.4.6. Tissue processing using paraffin __ 41

3.2.4.7. Gallyas silver impregnation ___ 41

3.2.4.8. Immunohistochemistry of paraffin embedded tissue ___ 42

3.2.4.9. Imaging and quantification of DAB developed stainings___ 43

3.2.5. Electron microscopy ___ 43

3.2.5.1. Tissue preparation _ـ 43

3.2.5.2. Epon embedding ___ 43

3.2.5.3. Sectioning of Epon embedded optic or sciatic nerves ___ 44

3.2.5.4. Staining of semi-thin sections___ 44

3.2.5.5. Contrasting of ultra-thin sections __ 44

3.2.5.6. Analysis of EM pictures __ 45

3.2.5.7. Immunoelectron microscopy ___ 45

3.2.6. Induction of experimental autoimmune encephalomyelitis in mice___ 45

4. Results 47

4.1. The septin cytoskeleton of central nervous system myelin _

4.1.1. Mass spectrometric and immunoblot characterization of mature CNS myelin _ 47

4.1.2. Subcellular localization of septins in mature CNS myelin _ $\quad 50$

4.2. Targeted loss of septins from oligodendrocytes _ 54

4.2.1. Generation of mice lacking SEPT8___ 54

4.2.2. SEPT8 is essential for the presence of the septin filament in CNS myelin ___ 58

4.2.3. SEPT8 deficient mice - development and behavior __ 60

4.2.4. Pathological abnormalities of septin-deficient CNS myelin___ 63

4.2.5. Secondary neuropathological effects in SEPT8 deficient mice ___ 66

4.3. Septins in peripheral myelin__ 71

4.3.1. Localization of septins in Schwann cells ___ 71

4.3.2. SEPT8 deficient Schwann cells ___ 72

5. Discussion _ 74

5.1. Septins are constituents of mature CNS myelin___ 74

5.2. Reduced abundance of myelin septins in mouse mutants affecting myelin-related genes $\quad 75$

5.3. SEPT8 is essential for septin filament assembly in CNS myelin _ 75

5.4. The presence of anillin in CNS myelin depends on septins__ $\quad 77$

5.5. Septins localize to internodal adaxonal myelin $\quad 78$

5.6. Mice lacking SEPT8 - development and behavior __ 79

5.7. Septin loss impairs the integrity of adaxonal myelin $\quad 79$

5.8. Secondary neuropathology in SEPT8-deficient mice ___ 81

5.9. Influence of septin deficiency on the disease course of EAE _ _ 82

5.10. Biology of septins in peripheral myelin ___ 83

6. References __ 85

Curriculum vitae 


\section{List of figures}

Fig. 1. Structure of myelinated axons.

Fig. 2. Oligodendroglial complexity.

Fig. 3. Dual nature of the immune response in the central nervous system.

Fig. 4. Biochemical characterization of CNS myelin.

Fig. 5. Septins localize to adaxonal CNS myelin.

Fig. 6. Septins localize to an internodal, adaxonal myelin subcompartment.

Fig. 7. The localization of SEPT9 in myelin is similar to that of SEPT8.

Fig. 8. Generation of mice harboring altered alleles of the Sept8 gene.

Fig. 9. Deletion of SEPT8-expression from oligodendrocytes.

Fig. 10. Post-translational loss of myelin septins when SEPT8 is lacking.

Fig. 11. Weight and motor capabilities of SEPT8-mutant mice.

Fig. 12. Brain structure and general myelination of SEPT8-mutant mice.

Fig. 13. Myelin abnormalities when SEPT8 is lacking.

Fig. 14. Myelin thickness and pathology in the optic nerve of SEPT8-mutant mice.

Fig. 15. Axonal pathology in SEPT8-deficient mice.

Fig. 16. Inflammation in SEPT8-deficient mice.

Fig. 17. Inflammation after EAE induction in SEPT8-mutants.

Fig. 18. Abaxonal localization of septins in peripheral myelin.

Fig. 19. Analysis of the PNS in SEPT8-deficient mice.

Fig. 20. Myelin septin filament assembly.

Fig. 21. Model of membrane association by myelin septins.

Fig. 22. A comparison of features of myelin septins in the CNS and the PNS. 


\section{Abbreviations}

\begin{tabular}{|c|c|}
\hline APP & Amyloid beta precursor protein \\
\hline APS & Ammonium persulfate \\
\hline Bp & Base pairs \\
\hline BSA & Bovine serum albumin \\
\hline${ }^{\circ} \mathrm{C}$ & Degrees Celsius (centigrades) \\
\hline CNP & 2'3'-cyclic nucleotide 3'phosphodiesterase \\
\hline CNS & Central nervous system \\
\hline COND & Conditional mutant \\
\hline DAB & 3,3'-Diaminobenzidine \\
\hline DAPI & 4'-6-Diamidino-2-phenylindole \\
\hline $\mathrm{dd}_{2} \mathrm{O}$ & Double distilled (or miliQ) water \\
\hline ddDNA & Double stranded DNA \\
\hline DMSO & Dimethylsulfoxide \\
\hline DPSS & Diode-pumped solid-state \\
\hline EAE & Experimental autoimmune encephalomyelitis \\
\hline EDTA & Ethylened acid \\
\hline e.g. & Exempli gratia \\
\hline EM & Electron microscopy \\
\hline ES & Embryonic stem cell \\
\hline f.c. & Final concentration \\
\hline g & Standard gravity \\
\hline GS & Goat serum \\
\hline HE & Haematoxylin-Eosin staining \\
\hline $\mathrm{He} / \mathrm{Ne}$ & Helium/Neon \\
\hline HNA & Hereditary neuralgic amyotrophy \\
\hline HS & Horse serum \\
\hline IB & Immunoblot \\
\hline IEM & Immunoelectron microscopy \\
\hline $\mathrm{IHC}$ & Immunohistochemistry \\
\hline JXP & Juxtaparanode \\
\hline $\mathrm{kDa}$ & Kilodalton \\
\hline KO & Constitutive mutant \\
\hline M & Molar \\
\hline$\mu \mathrm{M}$ & Micromolar \\
\hline $\mathrm{mM}$ & Millimolar \\
\hline
\end{tabular}




\begin{tabular}{|c|c|}
\hline $\mathrm{mA}$ & Milliampere \\
\hline $\min$ & Minutes \\
\hline $\mathrm{ml}$ & Milliliter \\
\hline MS & Mass spectrometry \\
\hline$\mu g$ & Microgram \\
\hline$\mu l$ & Microliter \\
\hline MPI & Max-Planck-Institute \\
\hline ng & Nanogram \\
\hline n.s. & Non-significant \\
\hline$\mu \mathrm{m}$ & Micrometer \\
\hline $\mathrm{nm}$ & Nanometer \\
\hline OL & Oligodendrocytes \\
\hline$o / n$ & Overnight \\
\hline$p$ & P-value \\
\hline$P$ & Postnatal day \\
\hline PAGE & Polyacrylamid gel electrophorese \\
\hline PBS & Phosphate buffered saline \\
\hline PCR & Polymerase chain reaction \\
\hline PFA & Paraformaldehyde \\
\hline $\mathrm{Pl}(4,5) \mathrm{P} 2$ & Phosphatidylinositol 4,5-bisphosphate \\
\hline PLP & Proteolipid protein \\
\hline PMSF & Phenylmethanesulphon \\
\hline PNS & Peripheral nervous system \\
\hline $\mathrm{PL}$ & Paranodal loop \\
\hline Rpm & Revolutions per minute \\
\hline $\mathrm{RQ}$ & Relative quantity \\
\hline $\mathrm{RT}$ & Room temperature \\
\hline RT-PCR & Quantitative real time PCR \\
\hline SC & Schwann cell \\
\hline $\sec$ & Seconds \\
\hline SD & Standard deviation \\
\hline SDS & Sodium dodecyl sulfate \\
\hline SEM & Standard error of the mean \\
\hline SPJ & Septate-like junction \\
\hline ssDNA & Single stranded DNA \\
\hline TBS & Tris buffered saline \\
\hline TEMED & Tetramethylendiamin \\
\hline
\end{tabular}




$\begin{array}{ll}\text { WT } & \text { Wild type (control) } \\ \text { w/v } & \text { Weight per volume } \\ \text { U } & \text { Unit, (for enzyme activities) } \\ \text { UV } & \text { Ultraviolet } \\ \text { V } & \text { Volt } \\ \text { v/v } & \text { Volume per volume } \\ \text { X-gal } & \text { 5-bromo4-chloro-3-indolyl- } \beta \text {-D-galactoside }\end{array}$




\section{Abstract}

Axonal integrity and longevity require functionally intact myelin, as demonstrated by the deletion of myelin-specific genes in mice. To identify molecules that contribute to the structural organization of CNS myelin, its protein content was systematically analyzed by quantitative proteome analysis. It was found that filament-forming septins are surprisingly abundant in myelin and we hypothesized that septin filaments may constitute a cytoskeletal membrane cortex. Here, I have investigated the exact subcellular localization and the pathobiological relevance of the septin cytoskeleton in myelinating glial cells. By immunohistochemistry, myelin septins were found to specify a novel subdomain in the internodal adaxonal compartment of CNS myelin, in which they assemble as filamentous structures gently undulating along the internodal segment of axons. Targeted deletion of the Sept8-gene, which encodes the most abundant myelin septin, led to secondary diminishment of SEPT2, SEPT4, SEPT7 and SEPT9 in myelin. SEPT8 is thus essential for the assembly of the CNS myelin septin filament. By quantitative mass spectrometry, the septin-polymerizing protein anillin was also diminished in SEPT8-deficient myelin, demonstrating a reverse effect of septins on anillin. Importantly, the targeted loss of SEPT8 and its associated proteins led to pathological outfoldings of myelin, indicating for the first time that the myelin septin filament prevents the emergence of this very specific pathology. Interestingly, myelin outfoldings alone did not induce axonal pathology or neuroinflammation. Only when further challenged, e.g. by a reduced abundance of the myelin protein CNP or the induction of $E A E$, the altered myelin structure triggered enhanced neuroinflammation. I have also approached the septin cytoskeleton of peripheral myelin. Interestingly, in Schwann cells, the subunit composition of septin filaments partly differs from that of CNS myelin and septins localize to the abaxonal compartment of peripheral myelin termed the bands of Cajal. The targeted deletion of SEPT8 did not lead to a loss of the PNS myelin septin filament, most likely because of a compensatory increase in the abundance of the closely related SEPT11. Together, septin filaments emerge as a newly identified stabilizer of the myelin sheath with pathobiological relevance. 


\section{Introduction}

\subsection{Cells of the nervous system}

Multicellular organisms have evolved over 500 million years ago, when cells that cooperated with others gained an evolutionary advantage. These associations were the basis for the evolution of a variety of species. Highly specific cell types evolved, which formed complex tissues, such as in the nervous system. In species of both, the protostomia and the deuterostomia clade, neurons interconnect and provide the capacity to control behavior and to store memories (Alberts, 2002). Glial cells, a group of nonneuronal cell types in the nervous system, are believed to support neuronal functions (Kettenmann and Ransom, 2005).

In the mammalian central nervous system (CNS), glial cells are subdivided in astrocytes, oligodendrocytes, and microglia (Kettenmann and Ransom, 2005). Astrocytes were shown to support neurons by transferring nutrients, e.g. lactate, and by discarding neurotransmitters from the synaptic cleft (Kettenmann and Ransom, 2005). Microglia originate from the immune system. They remove cell debris and have partially supportive functions in phases of cell stress and regeneration (Kettenmann and Ransom, 2005, Ransohoff and Cardona, 2010). Oligodendrocytes form very long processes and wrap them closely around axonal segments. By insulating axons at the internodes and thereby restricting action potentials to the nodes of Ranvier, they are the basis for fast saltatory nerve conduction (Baumann and Pham-Dinh, 2001, Kettenmann and Ransom, 2005). Similar to oligodendrocytes in the CNS, Schwann cells myelinate axons in the peripheral nervous system (PNS) and are thus essential for fast signal propagation as well (Jessen and Mirsky, 2005, Kettenmann and Ransom, 2005).

\subsection{Assembly and structural organization of myelin}

Oligodendrocytes and Schwann cells differ regarding their structural organization and their mechanisms to achieve myelination (Fig. 1A). Oligodendrocytes are multipolar cells and form several processes, which myelinate many axonal segments. In contrast, Schwann cells are bipolar cells and enwrap only one axonal segment each. In both cases, myelin is a specialized, vital compartment of the cell, which can further be subdivided in compact and non-compact myelin (Arroyo and Scherer, 2000, Poliak and Peles, 2003). Compact myelin consists of several layers of plasma membrane, which are adhesive. In particular, myelin basic protein (MBP) was shown to be an essential adhesion protein in the CNS myelin while in the PNS myelin protein zero (MPZ, P0) contributes additionally (Dupouey et al., 1979, Martini et al., 1995). The non-compact myelin compartment, which is devoid 
of these adhesion proteins, consists of adaxonal myelin, abaxonal myelin, incisures and paranodal loops (PL), differently organized in CNS and PNS (Fig. 1B). These domains, contrary to compact myelin, contain cytoskeletal elements and cytoplasm. (Arroyo and Scherer, 2000, Poliak and Peles, 2003).
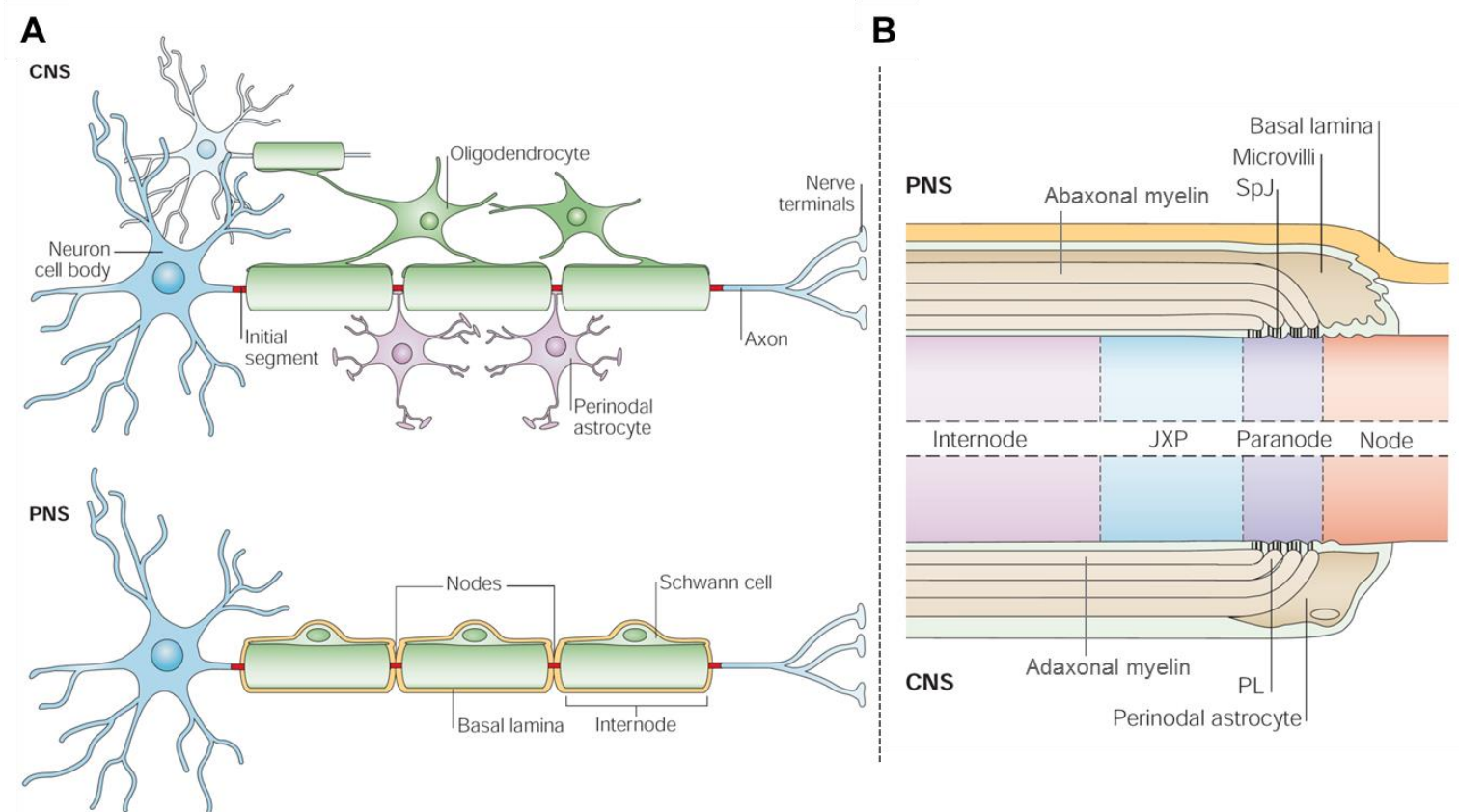

Fig. 1. Structure of myelinated axons. A Oligodendrocytes and Schwann cells form myelin of different structural organization. Oligodendrocytes cover multiple axonal segments whereas Schwann cells cover only one. Nonetheless, both provide the basis for saltatory signal propagation. B Myelin is a complex structural specialization of the cell consisting of compact and non-compact myelin. Myelination of an axon leads to the longitudinal molecular and structural specialization of axonal segments: internode, juxtaparanode (JXP), paranode and node (Poliak and Peles, 2003) (adapted image from Poliak and Peles, 2003).

Glial and axonal membranes are tightly connected and depend on each other (Fig. 1B). For instance, the paranodal loops form septate-like junctions (SpJ) with the axon and were shown to directly influence the distribution of sodium channels at the node of Ravier and potassium channels at the juxtaparanode (JXP) (Poliak and Peles, 2003, Rasband, 2011). Furthermore, the adaxonal membranes cover a large proportion of the axon at the juxtaparanodes and the internodes, therefore excluding other cellular interactions. The hypothesis was raised that intercellular exchange with oligodendrocytes supports axonal functions e.g. by release of monocarboxylates or exosomes (Kramer-Albers et al., 2007, Rinholm et al., 2011). Therefore, the adaxonal internodal compartment of myelin appears suitable. Recently, it was demonstrated that trophic support by oligodendrocytes is indeed of relevance for the long-term integrity of neurons (Nave, 2010, Funfschilling et al., 2012, Lee et al., 2012). 


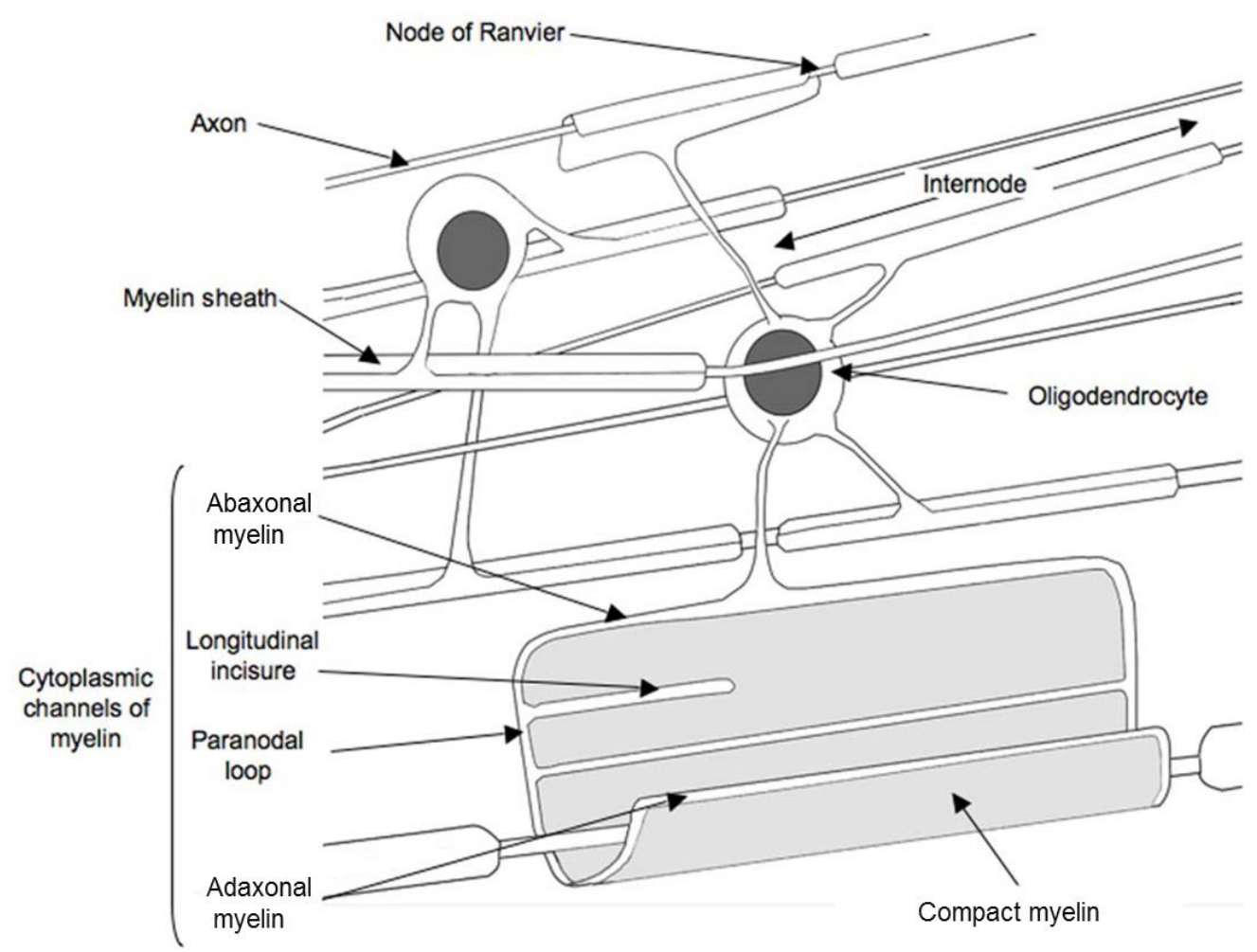

Fig. 2. Oligodendroglial complexity. To visualize the compact and the non-compact compartments of myelin, an oligodendroglial process was schematically unwrapped. Cytosolic channels in the myelin sheath demonstrate the specialization of oligodendroglial processes. Regulated transport of molecules takes place along these channels (Brahic and Roussarie, 2009) (adapted image taken from Brahic and Roussarie, 2009).

Complex molecular mechanisms underlie the transport of molecules to the outermost adaxonal myelin compartment (Fig. 2). By electron microscopy, microtubules and multivesicular bodies were visualized within adaxonal myelin disclosing the existing pathways in non-compact myelin (Mobius et al., 2010). For instance, mRNA encoding MBP was shown to be transported into the periphery of the myelinating cells and translated locally (Colman et al., 1982). Interestingly, other cytoskeletal elements such as actin and intermediary filaments are diminished in and may even be absent from mature myelin (Wilson and Brophy, 1989, Richter-Landsberg, 2001, Jahn et al., 2013).

Taken together, oligodendrocytes form complex cellular processes with a highly specialized molecular composition to enwrap axons for fast nerve conduction velocity and for axonal support. However, knowledge of the molecular basis for these processes has remained limited. 


\subsection{Axonal pathology related to oligodendroglial dysfunction}

Dysfunction of oligodendrocytes has secondary consequences for the integrity of axons. The analysis of mouse mutants lacking the expression of particular myelin proteins has demonstrated the relevance of a functional glia-axonal association. In particular, when genes encoding for proteolipid protein (PLP), a protein of compact myelin, or 2'3'-cyclic nucleotide 3'phosphodiesterase (CNP), a protein of non-compact myelin, were deleted in mice, oligodendrocytes were able to form myelin. However, unexpected at that time, axonal degeneration was observed (Klugmann et al., 1997, Griffiths et al., 1998, LappeSiefke et al., 2003).

The structural changes of the axon-myelin unit in both mutants were closely analyzed. In mice lacking the expression of PLP, myelin has been reported to also lack the adhesive radial component, which may contribute to incomplete compaction of myelin layers (Rosenbluth et al., 2006). However, there is no published evidence of PLP itself having adhesive properties. The presence of loose myelin layers observed in some reports may be the result of poor fixation (Mobius et al., 2008). Furthermore, an increased number of small non-myelinated axons has been identified, demonstrating a moderate delay in myelin biogenesis when PLP is lacking (Yool et al., 2001). It was recently shown that the association of PLP with cholesterol, an abundant myelin lipid, together with the related proteolipid GPM6B might be important for the trafficking of prospective myelin membrane during in myelin biogenesis (Werner et al., 2013). In addition, the axonal transport was found to be impaired (Edgar et al., 2004). In mice lacking the expression of CNP, swellings affecting the inner (non-compacted) layer of myelin (adaxonal myelin) have been observed (Edgar et al., 2009), possibly reflecting the disability to establish a balance between import and export of molecules. Interestingly, it was reported that CNP-deficiency leads to decreased process outgrowth of cultured oligodendrocytes by affecting tubulin polymerization (Lee et al., 2005). This suggests a mechanism according to which an impaired transport through the channels of non-compact adaxonal myelin may be involved in the emergence of axonal pathology. Additionally, axonal proteins, such as sodium channels at the nodes of Ranvier and Caspr at the paranodes, were reported to be mislocalized in the optic nerve of CNP-deficient mice upon aging, also suggesting impaired axon-glia interactions (Rasband et al., 2005).

Yet, a common molecular pathway, which could have elucidated the mechanism on how oligodendrocytes support the integrity of axons, has not been identified. Mice lacking both, PLP and CNP, displayed enhanced axonal pathology, suggesting at least two coexisting (possibly overlapping) pathways (Edgar et al., 2009). Thus, the molecular basis for the contribution of oligodendrocytes to axonal integrity remains to be revealed. This is of great 
interest, since the prevention of axonal degeneration is one challenge to achieve healthy longevity.

\subsection{Relevance of myelin thickness and integrity}

The process of myelination is tightly regulated. Axonal signals that regulate myelin thickness include neuregulin in the PNS, while responsible molecules are still elusive in the CNS (Michailov et al., 2004, Brinkmann et al., 2008). However, several molecular pathways contributing to myelin thickness intrinsic to oligodendrocytes have been identified.

The amount of myelin is measured by dividing the axonal by the myelin diameter (g-ratio). Amazingly, the ratio is constantly between 0.6 and 0.8 , optimal for signal propagation (Hildebrand and Hahn, 1978, Chomiak and Hu, 2009). The analysis of several mouse mutants has demonstrated that the maintenance of myelin thickness is crucial. For instance, the targeted loss of PTEN from oligodendrocytes, a negatively regulator of the mTOR pathway, led to an increase of myelin gene expression and enhanced myelin thickness (Goebbels et al., 2010). These mice live only up to 4 months, which has suggested that increased myelin thickness myelin is a disadvantage. Furthermore, these mice develop a pathologically abnormal myelin structures (myelin outfoldings). Hence, myelin integrity might influence axonal health additionally to the proposed trophic support.

In similarity, pathological outfoldings of myelin have been observed when the gene encoding CDC42 was deleted though without alterations of myelin thickness (Thurnherr et al., 2006). CDC42 is a Rho-GTPase involved in several regulatory pathways, which prevented the identification of the responsible downstream effectors. Nevertheless, this observation has provided evidence that various pathways contribute to the prevention of pathological myelin outfoldings.

\subsection{Septins}

In myelin of the central and the peripheral nervous system, several members of the septin protein family were recently identified as abundant components (Buser et al., 2009, Patzig et al., 2011). The interest in these novel myelin proteins has been accelerated by the finding that a number of septins were reduced in PLP-deficient CNS myelin, and in myelin lacking the lipid-modifying enzyme CGT (Werner et al., 2007, Fewou et al., 2010). However, their functional requirement in myelin and for axonal function has yet remained unknown. 
Septins are GTP-binding proteins expressed in all eukaryote clades except plants (Pan et al., 2007, Hall et al., 2008). They were first discovered in yeast as essential for cell division (Hartwell, 1971). Depending on GTP-binding, septin monomers polymerize to form hetero-oligomers and can further assemble into higher order structures, such as rings or filaments (Mendoza et al., 2002, Oh and $\mathrm{Bi}, 2011$ ). The latter were first described as filaments of $10 \mathrm{~nm}$ diameter located at the point of septation between mother and daughter cell of Saccharomyces cerevisiae, according to which they were named septins (Byers and Goetsch, 1976, Haarer and Pringle, 1987, Hall and Russell, 2012).

13 septin genes (with several splice variants) exist in mice and humans, namely Sept1Sept12 and Sept14 (Macara et al., 2002, Cao et al., 2007). The human Sept13 has recently been confirmed as a pseudogene of Sept7 (HGNC: 32339). Additional to being partially important in cell division (Hall and Russell, 2004, Kremer et al., 2007, Fuchtbauer et al., 2011), mammalian septins have been shown to act as scaffold proteins and diffusion barriers in various cell types (Hall and Russell, 2012, Spiliotis and Gladfelter, 2012). Based on their capacity to form filaments, their interaction with tubulin and actin in at least some systems, and their influence on cell morphology, septins are believed to constitute a fourth type of cytoskeleton (Mostowy and Cossart, 2012).

Mammalian septins are subdivided in four groups according to their sequence homology (Macara et al., 2002, Kinoshita, 2003). Their interactions have been studied extensively, and it emerged that within a hetero-oligomer, septins of different homology groups interconnect in a molar 1:1:1 ratio (Kinoshita, 2003). For example, an oligomer consisting of SEPT2, SEPT6, and SEPT7 has been shown to assemble into filaments in vitro, and its crystal structure was revealed (Sheffield et al., 2003, Low and Macara, 2006, Sirajuddin et al., 2007). By interacting with membrane lipids, the hetero-oligomers further polymerize and form a meshwork, in some respects similar to the actin cytoskeleton, but of considerable rigidity due to comparably low dynamics. Considering their association with plasma membranes, the stabilization of membranes has been suggested as one major function of septin filaments (Tanaka-Takiguchi et al., 2009, Gilden and Krummel, 2010).

\subsection{Septin functions in post-mitotic mammalian cells}

Septins have been shown to have various functions in post-mitotic cells. By knockdown/overexpression experiments in vitro or by deletion in vivo, the biology of septins in mammalian cells has been studied. These analyses demonstrate features, which might also apply to myelin septins. For instance, when the gene encoding SEPT4 was constitutively deleted in mice, one striking finding was the infertility of males due to 
morphological changes of sperm cells (Kissel et al., 2005). SEPT4, likely required as a central monomer of a filament, was shown to localize to the annulus of the sperm cell thereby separating head and tail. Upon the loss of SEPT4, separation did not occur. Hence, it was shown that septins perform a function as a diffusion barrier for membrane domains (Kwitny et al., 2010). Similar findings regarding septin function as a diffusion barrier have been shown for cilia (Hu et al., 2010).

The gene encoding SEPT5 was deleted in mice to define the function of septins in neurons (Peng et al., 2002). These mice developed largely normal though changes in the abundance of other septin have been shown in a preparation of synaptic vesicles. This has suggested a possible redundancy of closely homologous septins. However, the targeted deletion of both SEPT3 and SEPT5 has not led to a measurable effect on the development of hippocampal neurons (Tsang et al., 2011). Nevertheless, further studies of SEPT5 exposed alterations in the early development of synapses in vivo. It was revealed that indeed SEPT5 influences docking of synaptic vesicles, at least in immature presynapses (Yang et al., 2010). It has been postulated that a meshwork of SEPT5containing filaments covers the cytosolic surface of the presynaptic membrane and thereby reduces docking events. Therefore, it has been suggested that septins might also affect the transport and fusion of vesicles in other cells (Gilden and Krummel, 2010).

Septins have also been shown as abundant in dendritic spines (Tada et al., 2007, Xie et al., 2007). For example, the number of protrusions on dendrites and the size of dendritic spines were altered by knockdown or forced expression of SEPT7. This has suggested that membrane rigidity is influenced by septins in dendrites, and that their deletion leads to a decrease of protrusions and to a larger number of immature spines.

In similarity, membrane rigidity is influenced by septins in cultured amoeboid T-cells. Knockdown of SEPT7, and consequently of the SEPT7-containing septin filament, led to increased uropod length, correlating with diminished membrane rigidity (Tooley et al., 2009). Additionally, the presence of septin filaments was associated with decreased membrane flexibility (Gilden et al., 2012).

In summary, several functions of septins have been shown in post-mitotic cells. In particular, the capacity to enhance membrane rigidity appears of relevance for a cytoskeletal element in the myelin sheath. Nevertheless, functions such as a diffusion barrier or in vesicle transport are also conceivable. The functional relevance of the septin cytoskeleton is the key topic of this thesis. 


\subsection{Inflammation in the central nervous system}

Microglia are the main cell type of the innate immune system of brain and spinal cord (Rivest, 2009, Ransohoff and Cardona, 2010). They are widely distributed in the CNS and were shown to dynamically explore their tissue environment (Nimmerjahn et al., 2005). In models of myelin dysfunction with axonal pathology, the immune system of the CNS is 'activated'. Upon activation, microglia proliferate, their morphology changes and they start to express marker genes of macrophages (Ransohoff and Brown, 2012). The underlying mechanisms and the role in pathological situations are under intense investigation.

Several scenarios of microglial activation have been described (Rivest, 2009). Alterations affecting myelin or signals presented by oligodendrocytes might directly trigger microglial activation. For instance, it was shown that vesicles containing myelin proteins are taken up by microglia (Fitzner et al., 2011). Therefore, impairment of oligodendrocyte-derived signals might well affect the fate of microglia. Furthermore, myelin and myelin proteins are able to trigger immune responses (Pinteaux-Jones et al., 2008). Hence, axonal degeneration could result from chronic microglial activation (Fig. 3). Thus, removal of myelin debris is required for normal brain development and might be beneficial in several diseases (Yong and Rivest, 2009).

One the other hand, stressed axons can activate microglia. For instance, ATP and glutamate release by axons causes microglial activation. This leads to the release of TNFa, which has been shown to be protective for neurons (Lambertsen et al., 2009). Furthermore, amyloid precursor protein (APP) accumulations in axons are processed and internalized by microglia. Continuous impairment affecting axonal transport and therefore the accumulation of APP might lead to constant pro-inflammatory cues (Rivest, 2009).

Taken together, it has remained speculative if the deletion of oligodendroglial proteins or the resulting axonal pathology activates microglia. 


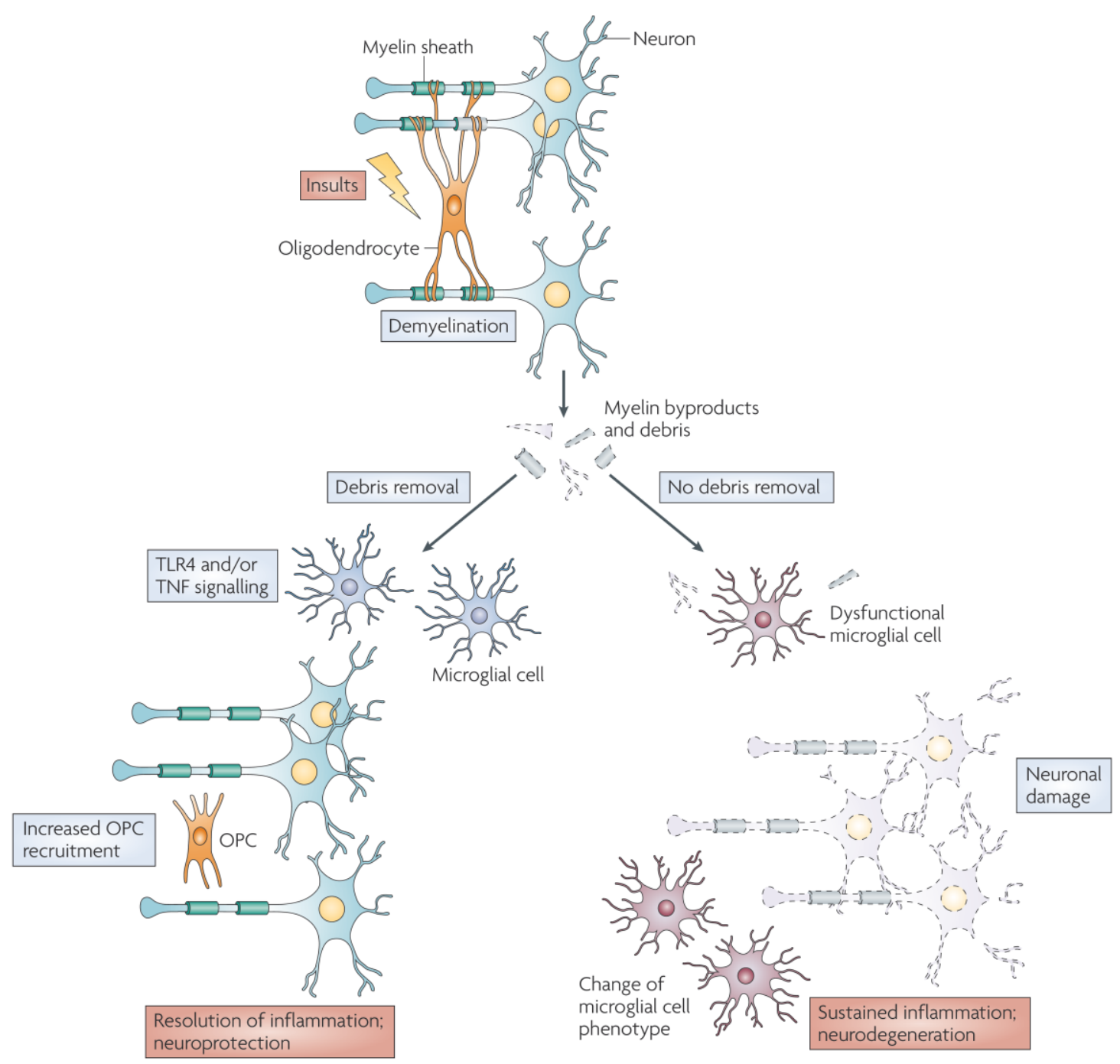

Fig. 3. Dual nature of the immune response in the central nervous system. Microglia respond to several extracellular cues. The resulting activation may be either beneficial or detrimental for axonal survival. Removal of cell debris and release of TLR4 or TNF by microglia support regeneration. In contrast, chronic or false activation can lead to axonal degeneration (Rivest, 2009) (Image taken from Rivest,2009). 


\subsection{Aim of the study}

Several proteins of the septin family have recently been identified as abundant constituents of myelin. Also considering prior knowledge about the biology of septins in other cell types, we have hypothesized that septins are relevant for the biogenesis or maintenance of myelin. The aim of this study is thus to uncover the function of myelin septins in vivo, in particular in the central nervous system. The relevance of this analysis has been triggered by the 2D-DIGE-based finding that the abundance of myelin septins is decreased in myelin of the PLP-deficient mouse model with secondary axonal pathology. These findings are to be validated using gel-free, quantitative mass spectrometry and compared to myelin of CNP-deficient mice, which also exhibit secondary axonal pathology. As a basis for understanding the function of myelin septins, their exact localization is to be visualized by immunohistochemistry and immunoelectron microscopy. To test the functional requirement of myelin septins, SEPT8 is to be deleted in oligodendrocytes and Schwann cells of mice. Septins have been described to assemble as filaments. Therefore, secondary changes to the abundance of other septins upon the deletion of SEPT8 are of interest. Quantitative mass spectrometry is to be used to analyze systematically such changes in SEPT8-deficient myelin. Immunoblot analysis is to be used to validate eventual findings. This strategy will also allow the unbiased identification of possible interacting proteins dependent in their abundance on myelin septins. Equally important, the structural consequences of the absence of SEPT8 from myelin are to be analyzed in detail. As oligodendrocytes support axonal integrity, secondary pathologies are to be studied in SEPT8-deficient mouse brains by immunohistochemistry, including markers for axonal degeneration and for neuroinflammation. As oligodendrocytes and Schwann cells differ with respect to myelin structure and protein composition, the localization and the functional relevance of septins may differ between CNS and PNS myelin. Therefore, the localization of septins and the functional consequences of the deletion of SEPT8 are also to be characterized in the peripheral nervous system. 


\section{Material and Methods}

\subsection{Material}

\subsubsection{Kits and chemicals}

All chemicals were purchased from Sigma-Aldrich $\mathrm{GmbH}$ (Munich, Germany), Merck KGaA (Darmstadt, Germany) and SERVA (Heidelberg, Germany) unless stated otherwise. General laboratory materials were from BD Falcon (Heidelberg, Germany), Biorad (München, Germany) Gilson (Limburg-Offheim, Germany), Brand (Radebeul, Germany) and Eppendorf (Hamburg, Germany).

\section{Kits}

RNA purification 'RNeasy mini prep' Qiagen (Portland, USA)

DC Protein Assay (Lowry) Bio-Rad (Munich, Germany)

$\mathrm{LSAB}_{2}$ kit

Dako (Hamburg, Germany)

Vector Elite ABC Kit

Vector Labs (Loerrach, Germany)

DAB Zytomed Kit

Zytomed Systems GmbH (Berlin, Germany)

\subsubsection{Molecular biology}

\section{Modified Gitschier buffer (MGB)}

$67 \mathrm{mM} \quad$ Tris/HCl, $\mathrm{pH} 8.8$

$16.6 \mathrm{mM} \quad\left(\mathrm{NH}_{4}\right)_{2} \mathrm{SO}_{4}$

$6.5 \mathrm{mM} \quad \mathrm{MgCl}_{2}$

$0.5 \%[\mathrm{v} / \mathrm{v}] \quad$ Triton $\mathrm{X}-100$

\section{Proteinase K (10 mg/ml)}

Added to MGB buffer before use for tail digest

Final concentration $1 \mathrm{mg} / \mathrm{ml}$

\section{$10 \mathrm{mM}$ dNTP (50x stock)}

$2.5 \mathrm{mM}$ each nucleotide (dATP, dCTP, dGTP, dTTP) (Boehringer-Ingelheim, Germany) $200 \mu \mathrm{M}$ final concentration in a PCR reaction (50 $\mu \mathrm{M}$ each nucleotide)

\section{0x Trisacetate EDTA (TAE) buffer}

$\begin{array}{ll}2.0 \mathrm{M} & \text { Tris/Acetate, } \mathrm{pH} 8.0 \\ 50 \mathrm{mM} & \text { EDTA } \\ 17.5 \%[\mathrm{v} / \mathrm{v}] & \text { Glacial acetic acid }\end{array}$




\section{Enzyme}

GOTaq DNA polymerase

Promega (Mannheim, Germany)

Superscript III-reverse transcriptase

Invitrogen (Karlsruhe, Germany)

\section{DNA marker}

GeneRuler 100 bp DNA ladder

Thermo Scientific (St. Leon-Rot, Germany)

\subsubsection{Protein biochemistry buffers}

10x Phosphate buffered saline (PBS)

$1.7 \mathrm{M} \quad \mathrm{NaCl}$

$34 \mathrm{mM} \quad \mathrm{KCl}$

$40 \mathrm{mM} \quad \mathrm{Na}_{2} \mathrm{HPO}_{4} \times 2 \mathrm{H}_{2} \mathrm{O}$

$18 \mathrm{mM} \quad \mathrm{K}_{2} \mathrm{HPO}_{4}$

$\mathrm{pH} 7.2$ with $1 \mathrm{~N} \mathrm{NaOH}$.

10x Tris-buffered saline (TBS)

$500 \mathrm{mM} \quad$ Tris $/ \mathrm{HCl}, \mathrm{pH} 7.5$

$1.5 \mathrm{M} \quad \mathrm{NaCl}$

Modified RIPA buffer (protein lysis buffer)

$1 \mathrm{x} \quad$ TBS

$1 \mathrm{mM} \quad$ EDTA

$0.5 \%[\mathrm{w} / \mathrm{v}] \quad$ Sodium deoxycholate

$1.0 \%[\mathrm{v} / \mathrm{v}] \quad$ Triton X-100

Complete Mini protease inhibitor (Roche Diagnostics $\mathrm{GmbH}$, Mannheim, Germany) 1 tablet/10ml of RIPA buffer

Protease inhibitor was added freshly to the RIPA buffer before use.

\subsubsection{SDS PAGE and immunoblot}

\section{SDS separating gel}

$12 \%$ or $10 \%[\mathrm{w} / \mathrm{v}] \quad$ Acrylamid/ Bisacrylamid $29: 1$

$0.4 \mathrm{M} \quad$ Tris/HCl pH 8.8

$0.1 \%[\mathrm{w} / \mathrm{v}] \quad$ SDS

$0.03 \%[\mathrm{w} / \mathrm{v}] \quad$ APS

$0.08 \%[\mathrm{v} / \mathrm{v}] \quad$ TEMED 


\section{SDS stacking gel}

$4 \%[\mathrm{w} / \mathrm{v}]$

Acrylamid/ Bisacrylamid 29:1

$125 \mathrm{mM}$

Tris/ $\mathrm{HCl} \mathrm{pH} 6.8$

$0.1 \%[\mathrm{w} / \mathrm{v}]$

SDS

$0.05 \%[\mathrm{w} / \mathrm{v}]$

APS

$0.1 \%[\mathrm{v} / \mathrm{v}]$

TEMED

\section{4x SDS sample buffer}

$40 \%[\mathrm{v} / \mathrm{v}]$

Glycerol

$240 \mathrm{mM}$

Tris/HCl pH 6.8

$8 \%[\mathrm{w} / \mathrm{v}]$

SDS

$0.04 \%[\mathrm{w} / \mathrm{v}]$

Bromophenol blue

10x SDS running buffer (Laemmli buffer)

$250 \mathrm{mM}$

Tris base

$1.92 \mathrm{M}$

Glycine

$1 \%[w / v]$

SDS

Transfer buffer

$96 \mathrm{mM}$

Tris base

$78 \mathrm{mM}$

Glycine

$10 \%[\mathrm{v} / \mathrm{v}]$

Methanol

20x Tris buffered saline (TBS)

$1 \mathrm{M}$

Tris/ $/ \mathrm{HCl}, \mathrm{pH} 7.4$

$3 \mathrm{M}$

$\mathrm{NaCl}$

\section{1x TBS with Tween-20 (TBST)}

$50 \mathrm{mM}$

Tris/ $\mathrm{HCl}, \mathrm{pH} 7.5$

$150 \mathrm{mM}$

$\mathrm{NaCl}$

$0.05 \%[\mathrm{v} / \mathrm{v}]$

Tween-20

Immunoblot stripping buffer
$0.2 \mathrm{M}$
Glycine $/ \mathrm{HCl}, \mathrm{pH} 2.5$
$0.1 \%[\mathrm{v} / \mathrm{v}]$
Tween-20

\section{Immunoblot blocking buffer}

$5 \%[w / v]$

non-fat dry milk powder in 1x TBST

\section{Protein marker}

PageRuler Plus Prestained Protein Ladder 10-250K Fermentas (St. Leon-Rot, Germany) 


\section{Additional materials}

Enhanced Chemiluminescence (ECL) Immunoblot detection kit Western Lightning ${ }^{\text {TM }}$ PlusECL, Enhanced luminol reagent plus (Perkin Elmer Life Sciences, Inc., Rodgau, Germany).

ECL-Hyperfilms (Amersham Biosciences, Uppsala, Sweden)

PVDF membrane Hybond $\mathrm{P}$ pore size $0.45 \mu \mathrm{m}$ (Amersham Biosciences, Uppsala, Sweden)

\subsubsection{Solutions for Fixation}

\section{Avertin}

$2 \%[\mathrm{w} / \mathrm{v}] \quad$ 2,2,2 Tribromethanol 99\%

$2 \%[\mathrm{v} / \mathrm{v}] \quad$ Amylalkohol

Mixed at $40^{\circ} \mathrm{C}$ for 30 min while stirring and subsequently filtered

Stored at $-20^{\circ} \mathrm{C}$

$16 \%$ [w/v] Paraformaldehye (PFA)

$16 \%[\mathrm{w} / \mathrm{v}] \quad$ Paraformaldehyde cooked at $65^{\circ} \mathrm{C}$ for $20 \mathrm{~min}$ while stirring

$5 \mathrm{~N} \quad \mathrm{NaOH}$ droplets until solution was cleared and then filtered

0.2M Phosphate buffer (fixation buffer)

$0.36 \%[\mathrm{w} / \mathrm{v}] \quad$ Sodiumdihydrogenphosphate $\left(\mathrm{NaH}_{2} \mathrm{PO}_{4}\right)$

$3.1 \%[\mathrm{w} / \mathrm{v}]$ di-Sodiumhydrogenphosphate $\left(\mathrm{Na}_{2} \mathrm{HPO}_{4}\right)$

$1 \%[\mathrm{w} / \mathrm{v}] \quad$ Sodium chloride

4\% [w/v] Paraformaldehye (PFA, immunohistochemistry)

$4 \%[w / v] \quad$ PFA

$0.1 \mathrm{M} \quad$ Phosphate buffer

Karlsson-Schultz fixative (electron microscopy)

$4 \%[\mathrm{w} / \mathrm{v}] \quad$ PFA

$2.5 \%[\mathrm{v} / \mathrm{v}] \quad$ Glutaraldehyde

$0.1 \mathrm{M} \quad$ Phosphate buffer

Immuno Karlsson-Schultz fixative (immuno electron microscopy)

$4 \%[\mathrm{w} / \mathrm{v}] \quad$ PFA

$0.25 \%[v / v] \quad$ Glutaraldehyde

$0.1 \mathrm{M} \quad$ Phosphate buffer 


\subsubsection{Immunohistochemistry and staining solutions}

Phosphate buffer (0.2 M, pH 7.4)

$0.04 \mathrm{M} \quad$ Sodiumdihydrogenphosphate $\left(\mathrm{NaH}_{2} \mathrm{PO}_{4}\right)$

$0.16 \mathrm{M}$ di-Sodiumhydrogenphosphate $\left(\mathrm{Na}_{2} \mathrm{HPO}_{4}\right)$

Always prepared freshly

\section{Citrate buffer (0.01 M, pH 6.0)}

$1.8 \mathrm{mM} \quad$ Citric acid $\left(\mathrm{C}_{6} \mathrm{H}_{8} \mathrm{O}_{7} \cdot \mathrm{H}_{2} \mathrm{O}\right)$

$8.2 \mathrm{mM} \quad$ Sodium citrate $\left(\mathrm{C}_{6} \mathrm{H}_{5} \mathrm{O}_{7} \mathrm{Na}_{3} .2 \mathrm{H}_{2} \mathrm{O}\right)$

Always prepared freshly

\section{BSA/PBS}

0.04M Sodiumdihydrogenphosphate $\left(\mathrm{NaH}_{2} \mathrm{PO}_{4}\right)$

$0.16 \mathrm{M}$ di-Sodiumhydrogenphosphate $\left(\mathrm{Na}_{2} \mathrm{HPO}_{4}\right)$

$1.8 \%[\mathrm{w} / \mathrm{v}] \quad$ Sodium chloride

$1.0 \%[\mathrm{w} / \mathrm{v}] \quad$ Bovines serum albumin (BSA)

\section{Tris buffer (pH 7.6)}

$50 \mathrm{mM} \quad$ Tris/HCl, $\mathrm{pH} 7.6$

$0.9 \%[\mathrm{w} / \mathrm{v}] \quad$ Sodium chloride $(\mathrm{NaCl})$

Always prepared freshly.

Mayer's haematoxylin solution

$0.1 \%[\mathrm{w} / \mathrm{v}] \quad$ Haematoxylin

$0.02 \%[\mathrm{w} / \mathrm{v}] \quad$ Sodium iodate

$5 \%[\mathrm{w} / \mathrm{v}] \quad$ Potassium aluminium sulphate $\left(\mathrm{K}_{2} \mathrm{Al}_{2}\left(\mathrm{SO}_{4}\right)_{4} \cdot 24 \mathrm{H}_{2} \mathrm{O}\right)$

Added under constant shaking, solution turned violet blue

$5 \%[\mathrm{w} / \mathrm{v}] \quad$ Chloralhydrate

$0.1 \%[\mathrm{w} / \mathrm{v}] \quad$ Citric acid added

Added and filtered before use

Eosin solution

$0.1 \%[\mathrm{v} / \mathrm{v}] \quad$ Eosin

12 drops of glacial acetic acid in $250 \mathrm{ml}$

\section{Scott's solution}

$0.2 \%[\mathrm{w} / \mathrm{v}] \quad$ Potassiumhydrogencarbonate

$2 \%[\mathrm{w} / \mathrm{v}] \quad$ Magnesium sulphate 
$\mathrm{HCl}$ - alcohol

$0.09 \%[\mathrm{v} / \mathrm{v}] \quad \mathrm{HCl}$

$70 \%[\mathrm{v} / \mathrm{v}] \quad$ Ethanol

\section{$\beta$-Gal staining buffer}

$5 \mathrm{mM} \quad$ Potassium ferricyanid

$5 \mathrm{mM} \quad$ Potassium ferrocyanid

$2 \mathrm{mM} \quad \mathrm{MgCl}_{2}$

$1.2 \mathrm{mg} / \mathrm{ml} \quad$ 5-bromo-4-chloro-indolyl- $\beta$-D-galactopyranoside (X-gal)

Adjusted in 1x PBS

\section{Gallyas silver impregnation}

Incubation solution

$0.1 \%[\mathrm{w} / \mathrm{v}] \quad$ Ammonium nitrate

$0.1 \%[\mathrm{w} / \mathrm{v}] \quad$ Silver nitrate

$12 \%$ [w/v] Sodium hydroxide $(\mathrm{pH} 7.5)$

Brown precipitate dissolved by shaking, stored for 8-10 weeks.

Physical developer

Solution A $5 \%[\mathrm{w} / \mathrm{v}] \quad$ Sodium carbonate (dehydrated) in $\mathrm{H}_{2} \mathrm{O}$

Solution B $0.2 \%[\mathrm{w} / \mathrm{v}] \quad$ Ammonium nitrate

$0.2 \%[\mathrm{w} / \mathrm{v}] \quad$ Silver nitrate

$1 \%[\mathrm{w} / \mathrm{v}] \quad$ Wolframosilicic acid (silicotungstic acid)

Solution C $0.2 \%[\mathrm{w} / \mathrm{v}] \quad$ Ammonium nitrate

$0.2 \%[\mathrm{w} / \mathrm{v}] \quad$ Silver nitrate

$1 \%[\mathrm{w} / \mathrm{v}] \quad$ Wolframosilicic acid (silicotungstic acid)

$0.26 \%[\mathrm{w} / \mathrm{v}]$ Paraformaldehyde

To reconstitute physical developer: $70 \mathrm{ml}$ of solution B added to $100 \mathrm{ml}$ of solution A with constant and gentle shaking and then slowly added to $1000 \mathrm{ml}$ solution C.

Fixing solution

$2 \%[w / v] \quad$ Sodium thiosulphate

\section{Blocking buffer for cryosections}

$5 \%[\mathrm{v} / \mathrm{v}]$

Goat serum

$0.5 \%[\mathrm{v} / \mathrm{v}]$

Triton X-100

Dissolved in BSA/PBS 


\section{Blocking buffer for teased fibers}

$10 \%[\mathrm{v} / \mathrm{v}] \quad$ Horse serum

$0.1 \%[\mathrm{v} / \mathrm{v}] \quad$ Tween-20

Dissolved in $1 \times$ PBS

Mounting media

Eukitt

Kindler (Freiburg, Germany)

Aqua-Poly/Mount

Polysciences (Eppelheim, Germany)

\subsubsection{Electron microscopy}

\section{Epon}

Mixed 30 min before embedding in the following way:

$171.3 \mathrm{~g} \quad$ Glycidether 100

$115 \mathrm{~g}$ DDSA (Dodecenyl succinic anhydride)

$89 \mathrm{~g} \quad$ MNA (Methyl nadic anhydride)

Mixed using magnet stirrer for $10 \mathrm{~min}$ and then

$6.5 \mathrm{ml} \quad$ DMP-30

Added and mixed using magnet stirrer for $20 \mathrm{~min}$

Methylene blue - Azure II staining solution

Methylene blue

$1 \%[\mathrm{w} / \mathrm{v}] \quad$ Na-tetraborat (Borax)

$1 \%[\mathrm{w} / \mathrm{v}] \quad$ Methylenblau

Azure II

$1 \%[\mathrm{w} / \mathrm{v}] \quad$ Azure II

Methylene blue and Azure II were freshly mixed 1:1 before use. 


\subsubsection{Antibodies}

Primary antibodies

\begin{tabular}{|c|c|c|c|c|}
\hline Antibody & Species & Dilution & Purpose & Vendor \\
\hline APP & Monoclonal mouse & $1: 750$ & $\mathrm{IHC}$ & Chemicon \\
\hline Caspr & Monoclonal mouse & $1: 500$ & $\mathrm{IHC}$ & Neuromabs \\
\hline CNP & Monoclonal mouse & $1: 2000$ & IB & Sigma \\
\hline $\begin{array}{c}\text { FNP7 (pan } \\
\text { neurofilament) }\end{array}$ & Monoclonal mouse & $1: 500$ & IB & Zymed Lab. Inc. \\
\hline $\mathrm{Kv} 1.2$ & Monoclonal mouse & $1: 200$ & $\mathrm{IHC}$ & Neuromabs \\
\hline Mac3 & Monoclonal rat & $1: 500$ & $\mathrm{IHC}$ & Pharmingen \\
\hline MAG (513) & Monoclonal mouse & $1: 50$ & $\mathrm{IHC}$ & Chemicon \\
\hline PLP(A431) & Polyclonal rabbit & $1: 500$ & IB & K.-A. Nave \\
\hline SEPT2 & Polyclonal rabbit & $1: 500$ & IB & $\begin{array}{c}\text { Nicole Schaeren- } \\
\text { Wiemers }\end{array}$ \\
\hline SEPT4 & Polyclonal rabbit & $1: 500$ & IB & IBL \\
\hline SEPT7 & Polyclonal rabbit & $1: 5000$ & IB & IBL \\
\hline SEPT8 & Polyclonal rabbit & $1: 2000$ & IB & ProteinTechGroup \\
\hline SEPT8 & Polyclonal rabbit & $1: 50$ & IEM & ProteinTechGroup \\
\hline SEPT9 & Polyclonal rabbit & $1: 1000$ & IB & ProteinTechGroup \\
\hline SEPT9 & Polyclonal rabbit & $1: 50$ & IEM & ProteinTechGroup \\
\hline SEPT11 & Polyclonal rabbit & $1: 1000$ & IB & Koh-ichi Nagata \\
\hline Smi31 (NF) & Monoclonal mouse & $1: 1000$ & $\mathrm{IHC}$ & Covance \\
\hline a-tubulin & Monoclonal mouse & $1: 5000$ & IB & Sigma \\
\hline$\beta$-tubulin-3 & Monoclonal mouse & $1: 1000$ & IB & Covance \\
\hline
\end{tabular}


Secondary antibodies

\begin{tabular}{|c|c|c|c|c|}
\hline Antibody & Species & Dilution & Purpose & Vendor \\
\hline a-rabbit-HRP & Goat & $1: 10000$ & IB & Dianova \\
\hline a-mouse-HRP & Goat & $1: 10000$ & IB & Dianova \\
\hline a-rat-biotinylated & Rabbit & $1: 100$ & IHC & Vector \\
\hline a-rabbit-Alexa488 & Donkey & $1: 1000$ & IHC & Dianova \\
\hline a-rabbit-Cy3 & Goat & $1: 500$ & IHC & Dianova \\
\hline a-mouse-Cy3 & Goat & $1: 500$ & IHC & Dianova \\
\hline $\begin{array}{c}\text { a-mouse- } \\
\text { Dyelight633 }\end{array}$ & Donkey & $1: 500$ & IHC & Dianova \\
\hline $\begin{array}{c}\text { Colloidal gold } \\
\text { conjugates to } \\
\text { protein A }\end{array}$ & $\begin{array}{c}\text { Staphylococcus } \\
\text { aureus }\end{array}$ & $1: 50$ & IEM & $\begin{array}{c}\text { Cell Microscopy } \\
\text { Center, Department } \\
\text { of Cell Biology, } \\
\text { University Medical } \\
\text { Center Utrecht, The } \\
\text { Netherlands }\end{array}$ \\
\hline
\end{tabular}




\subsubsection{Oligonucleotides}

Oligonucleotides were synthesized by the service facility of the Max-Planck-Institute for Experimental Medicine.

Genotyping primer for various mouse lines (internal numbers)

Flp recombinase genotyping:

15300: 5'- CAC TGA TAT TGT AAG TAG TTT GC -3'

15301: 5'- CTA GTG CGA AGT AGT GAT CAG G -3'

Sept8 genotyping:

15048: 5'- CAACGGGTTCTTCTGTTAGTCC-3'

16458: 5'- CAGGCAGATGTATATGCAGCAG-3'

16459: 5'- GGTGGCTTTGAACTTGCTATCC-3'

16460: 5'- GAAGCAGCCATAGAGGAGATCC-3'

Cre recombinase genotyping:

2016: 5'- GCCTTCAAACTGTCCATCTC -3'

4192: 5'- CAGGGTGTTATAAGCAATCCC -3'

4193: 5'- CCTGGAAAATGCTTCTGTCCG -3'

7315: 5'- CCCAGCCCTTTTATTACCAC -3'

\section{Quantitative real-time PCR primers}

Anln

Forward: 5'- ACAATCCAAGGACAAACTTGC-3'

Reverse: 5'- GCGTTCCAGGAAAGGCTTA-3'

Ppia

Forward: 5'- CACAAACGGTTCCCAGTTTT -3'

Reverse: 5'- TTCCCAAAGACCACATGCTT-3' 
Sept2

Forward: 5'- TCCTGACTGATCTCTACCCAGAA-3'

Reverse: 5'-AAGCCTCTATCTGGACAGTTCTTT-3'

Sept4

Forward: $\quad$ 5'- ACTGACTTGTACCGGGATCG-3'

Reverse: 5'- TCTCCACGGTTTGCATGAT-3'

Sept7

Forward: 5'- AGAGGAAGGCAGTATCCTTGG-3'

Reverse: 5'- TTTCAAGTCCTGCATATGTGTTC-3'

Sept8

Forward: $\quad$ 5'- CTGAGCCCCGGAGCCTGT-3'

Reverse: 5'- CAATCCCAGTTTCGCCCACA-3'

Sept9

Forward: ['- GACTCCATCCTGGAGCAGAT-3'

Reverse: 5'- TTTGGACTTGAAGAGGGTATTGA-3'

\subsubsection{Mouse lines}

Plp1 $^{-/ Y}$ mice (Klugmann et al., 1997)

$\mathrm{Cnp1}^{-1 /}, \mathrm{Cnp} 1^{\mathrm{Cre} / \mathrm{wt}}$ mice (Lappe-Siefke et al., 2003)

Sept $4^{-/}$mice (Kissel et al., 2005)

Sept8 $8^{f / f t l}, S_{\text {Sept8 }}^{-/}$mice (Eucomm ES cells, Patzig et al., unpublished)

Mice expressing Flp recombinase body-wide (Farley et al., 2000)

Mice expressing Cre recombinase body-wide (Holzenberger et al., 2000) 


\subsection{Methods}

\subsubsection{Animals}

All animals used in experiments of this thesis were bred and kept in the mouse facility of the Max-Planck-Institute (MPI) for Experimental Medicine. All experiments were performed in accordance with the guidelines for German animal welfare. All mice were sacrificed by cervical dislocation or by perfusion using anesthetics.

\subsubsection{Generation of SEPT8 deficient mice}

To generate SEPT8 deficient mice, ES cells were obtained from the European Conditional Mouse Mutagenesis Program (EUCOMM). ES cells were grown in the department of Neurogenetics of the MPI for Experimental Medicine in Göttingen by Ulrike Bode. ES cells were injected into FVB blastula and implanted in NMRI foster mothers. Positive Chimaeras were bred to wild type C57BL/6N mice gaining F1 offspring. Sept8-LacZ animals, containing the whole cassette described in detail (Fig. 8B and http://www.knockoutmouse.org/martsearch/project/33205), were recognized by genotyping PCR and further bred to the Flp recombinase positive mouse line to remove the LacZ/neo cassette resulting in floxed mice for conditional gene targeting. Homozygous Sept8 floxed mice (Sept8 $\left.{ }^{f / f f}\right)$ together with heterozygous Cnp1 mice (Cnp1 $\left.1^{\text {cre/wt }}\right)$ (LappeSiefke et al., 2003) were used to delete SEPT8 in oligodendrocytes and Schwann cells

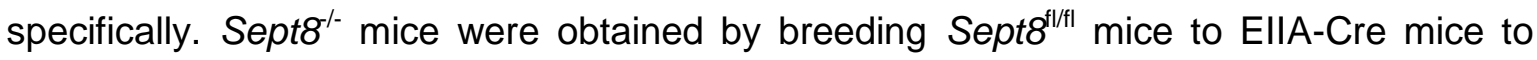
recombine the gene within the germ line. In all experiments Sept $8^{\mathrm{t} / / 1 / 1}$ mice and Sept $8^{\mathrm{wt} / \mathrm{wt}}$ mice were used as controls and labeled as WT. Sept ${ }^{f / / f t *} C n p 1^{\mathrm{cre} / \mathrm{wt}}$ mice were conditional mutants for Sept8 in oligondendrocytes and were labeled as COND. Sept8 ${ }^{-/}$, which did not express any SEPT8 isoform in any cell type, were constitutive mutants and were labeled as $\mathrm{KO}$.

\subsubsection{Genotyping of mice}

$0.5 \mathrm{~cm}$ long tail tips were taken from P21 young mice. They were digested overnight $(\mathrm{o} / \mathrm{n})$ in $180 \mu \mathrm{l} 1 \mathrm{xMGB}$ with $20 \mu \mathrm{l}$ Proteinase $\mathrm{K}$ at $55^{\circ} \mathrm{C}$ with agitation. To inactivate Proteinase $\mathrm{K}$, tails were incubated for $10 \mathrm{~min}$ at $95^{\circ} \mathrm{C}$. Polymerase chain reaction was used to amplify specific DNA segments (Mullis et al., 1986, Saiki et al., 1988). $1 \mu$ of DNA samples were used per $20 \mu \mathrm{l} \mathrm{PCR}$ reaction. Primers were selected manually using the DNASTAR Lasergene 9 core suite. 
PCR reaction Sept8 gene containing lacZ/neo (wild type 448bp, Sept8-LacZ226bp):
$4.2 \mu \mathrm{l} \quad$ Go-Taq buffer (5x)
$2.1 \mu \mathrm{l} \quad \mathrm{dNTP}(2 \mathrm{mM})$
$0.5 \mu \mathrm{l} \quad$ Primer $16459(10 \mu \mathrm{M})$
$0.5 \mu \mathrm{l} \quad$ Primer $16460(10 \mu \mathrm{M})$
$0.25 \mu \mathrm{l} \quad$ Primer $15048(10 \mu \mathrm{M})$
$0.08 \mu \mathrm{l} \quad$ GoTaq DNA polymerase
$\mathrm{dd}_{2} \mathrm{O}$ added to total of $20 \mu \mathrm{l}$.

PCR reaction to detect Flp recombinase:
$4.2 \mu \mathrm{l} \quad$ Go-Taq buffer $(5 \mathrm{x})$
$2.1 \mu \mathrm{l} \quad \mathrm{dNTP}(2 \mathrm{mM})$
$0.2 \mu \mathrm{l} \quad$ Primer $15300(10 \mu \mathrm{M})$
$0.2 \mu \mathrm{l} \quad$ Primer $15301(10 \mu \mathrm{M})$
$0.08 \mu \mathrm{l} \quad$ GoTaq DNA polymerase
$\mathrm{ddH} 2 \mathrm{O}$ added to a total of $20 \mu \mathrm{l}$.

PCR reaction Sept8 gene after FRT recombination (floxed $\sim 569 \mathrm{bp}$, null $\sim 256 \mathrm{bp}$ ):
$4.2 \mu \mathrm{l} \quad$ Go-Taq buffer (5x)
$2.1 \mu \mathrm{l} \quad \mathrm{dNTP}(2 \mathrm{mM})$
$0.1 \mu \mathrm{l} \quad$ Primer $16458(10 \mu \mathrm{M})$
$0.6 \mu \mathrm{l} \quad$ Primer $16459(10 \mu \mathrm{M})$
$0.6 \mu \mathrm{l} \quad$ Primer $16460(10 \mu \mathrm{M})$
$0.08 \mu \mathrm{l} \quad$ GoTaq DNA polymerase
$\mathrm{ddH}_{2} \mathrm{O}$ added to a total of $20 \mu \mathrm{l}$.

PCR reaction to detect Cre recombinase:
$4.2 \mu \mathrm{l} \quad$ Go-Taq buffer(5x)
$2.1 \mu \mathrm{l} \quad \mathrm{dNTP}(2 \mathrm{mM})$
$0.2 \mu \mathrm{l} \quad$ Primer $4391(10 \mu \mathrm{M})$
$0.2 \mu \mathrm{l} \quad$ Primer $4392(10 \mu \mathrm{M})$
$1 \mu \mathrm{l} \quad$ Primer $2016(10 \mu \mathrm{M})$
$1 \mu \mathrm{l} \quad$ Primer $7315(10 \mu \mathrm{M})$
$0.08 \mu \mathrm{l} \quad$ GoTaq DNA polymerase
$\mathrm{ddH}_{2} \mathrm{O}$ added to a total of $20 \mu \mathrm{l}$. 
For separation of the PCR products gels containing $2 \%[\mathrm{w} / \mathrm{v}]$ agarose in TAE buffer were used. For DNA visualization $1 \mu \mathrm{g} / \mathrm{ml}$ ethidiumbromide was added to the gel prior to polymerization. $20 \mu \mathrm{l}$ of PCR samples were loaded and separated at $150 \mathrm{~V}$ for $45 \mathrm{~min}$ in TAE buffer. GeneRuler 100 bp DNA ladder (Thermo Scientific, St. Leon-Rot, Germany) was used as a marker. For documentation pictures were obtained with the Intas UV system.

\subsubsection{Protein biochemical analysis}

\subsubsection{Sample preparation}

Collected tissue was quickly frozen on dry ice and stored at $-80^{\circ} \mathrm{C}$. Sciatic nerves were cut on dry ice and homogenized in RIPA buffer using the Precellys (Peqlab, Erlangen, Germany) (6500rpm, 3x $10 \mathrm{sec}$ ). Lysate was incubated at $4^{\circ} \mathrm{C}$ for $15 \mathrm{~min}$ and then centrifuged for $\quad 10 \mathrm{~min}$ at $13000 \mathrm{rpm}$ at $4^{\circ} \mathrm{C}$. Supernatant was transferred into a new tube and stored at $-80^{\circ} \mathrm{C}$. Protein concentration was measured and samples were used for SDS Page. Mouse brains were used for myelin purification.

\subsubsection{Myelin purification method}

The protocol is based on the Norton and Poduslo method (Norton and Poduslo, 1973, Larocca and Norton, 2007). All supplies were precooled and procedure was performed on ice or at $4^{\circ} \mathrm{C}$. Half brains were homogenized with the KINEMATICA AG POLYTRON PT 3000 in $0.32 \mathrm{M}$ sucrose containing protease inhibitor (Roche Diagnostics $\mathrm{GmbH}$, Mannheim, Germany). $200 \mu \mathrm{l}$ of brain lysates were stored at $-80^{\circ} \mathrm{C}$. For density gradient centrifugation, homogenate was overlaid on $0.85 \mathrm{M}$ sucrose and centrifuged for $30 \mathrm{~min}$ at $70000 x g$ in a swing out rotor (SW40Ti Beckman rotor, 24.400rpm) in the Beckman XL-70 ultracentrifuge. Using the Ultra-Clear Tubes (Beckman No. 344060) the interphase could be nicely seen and transferred into a new tube. Water was added to the collected material and centrifuged again at $70000 x$ for $15 \mathrm{~min}$. The Pellet was resuspended in water, incubated for $15 \mathrm{~min}$ and centrifuged at 12000xg for 15 min (SW40Ti Beckman rotor, 9700rpm). This so called osmotic shock was repeated a second time. Afterwards the pellet was resuspended in $0.32 \mathrm{M}$ sucrose and layered on $0.85 \mathrm{M}$ sucrose for a second sucrose gradient and centrifuged at $70000 \mathrm{xg}$ for $30 \mathrm{~min}$. The interphase was collected into a clean tube, water was added and it was centrifuged at $70000 \mathrm{xg}$ for $15 \mathrm{~min}$. The pellet containing a myelin enriched fraction was resuspended in $200 \mu \mathrm{l} 1 \mathrm{xTBS}$ including protease inhibitor (Roche Diagnostics $\mathrm{GmbH}$, Mannheim, Germany) and was stored at $80^{\circ} \mathrm{C}$. 


\subsubsection{Protein concentration measurement by the Lowry method}

The Protein concentration was measured using the Bio-Rad DC Protein Assay kit according to the manufacturer's 'microplate assay' protocol. The working principle of the kit is similar to the well-documented Lowry assay (Lowry et al., 1951, Peterson, 1979). The optical density was measured at $650 \mathrm{~nm}$ in the microplate reader ThermoMax (Molecular Devices, Biberach, Germany).

\subsubsection{Quantitative Mass Spectrometry}

Samples containing $100 \mu \mathrm{g}$ of myelin in 1xTBS (3x control and $3 x$ mutants from PLP-, CNP- and SEPT8-deficient mice) were sent to Dr. Stefan Tenzer, Institute for Immunology University Mainz. He analyzed these probes using LC-MS ${ }^{E}$, described in detail (Patzig et al., 2011). Experiments were performed using three biological each in four technical replicates. Final quantifications and diagrams were prepared with Microsoft Excel 2010 and GraphPad Prism 5.

\subsubsection{Separating Proteins using SDS Page}

$10 \%[\mathrm{w} / \mathrm{v}]$ or $12 \%[\mathrm{w} / \mathrm{v}]$ acrylamid gels were prepared using the Bio-rad system. For this, SDS separating gel mix was casted between a $1.5 \mathrm{mM}$ thick spacer plate and thin coverplates. It was overlaid with isopropanol and polymerized for at least $30 \mathrm{~min}$. The stacking gel mix was added on top after removing the isopropanol by washing with $\mathrm{dd}_{2} \mathrm{O}$. A Teflon comb (10 or 15 wells) was used to generate pockets for the protein sample. After polymerization gels were used immediately or were store wet at $4^{\circ} \mathrm{C}$, not longer than a week. Proteins were separated using the protocol established by Laemmli (Laemmli, 1970). To denature the proteins, lysates were mixed with $1 \times$ SDS sample buffer and $5 \%$ $[\mathrm{v} / \mathrm{v}]$ mecaptoethanol, and heated for $20 \mathrm{~min}$ at $40^{\circ} \mathrm{C}$. Bio-rad chambers were used to assemble the gels and filled with $1 x$ Laemmli running buffer. Wells were washed with the running buffer and the protein samples were carefully pipetted in. Proteins were separated by constant current using the Bio-rad power supply (30 mA per gel), proteins below 40 $\mathrm{kDa}$ on a $12 \%[\mathrm{w} / \mathrm{v}]$ gel, proteins above on a $10 \%[\mathrm{w} / \mathrm{v}] \mathrm{gel}$. After about one and a half hour, gels were removed, incubated for $15 \mathrm{~min}$ in transfer buffer and proteins were transferred to a PVDF membrane (immunoblot).

\subsubsection{Immunoblot}

For immunodetection, proteins were transferred to a PVDF membrane as described by Towbin and colleagues (Towbin et al., 1979). Therefore, the semi-dry chamber from Invitrogen (Karlsruhe, Germany) was used. The PVDF membrane was activated using $100 \%$ [v/v] methanol for 1 min, washed two times shortly with $\mathrm{dd}_{2} \mathrm{O}$ and kept in transfer 
buffer. Three Whatman papers soaked in transfer buffer were put onto the anode plate. On top, the activated PVDF membrane was layered, followed by the gel and three more Whatman papers. Proteins were transferred at $20 \mathrm{~V}$ for $40 \mathrm{~min}$.

\subsubsection{Immunodetection of blotted proteins}

After the protein transfer, the PVDF membrane was blocked at room temperature (RT) for 1 hour in blocking buffer ( $5 \%$ [w/v] non-fat dry milk in TBST). Primary antibody was diluted in the blocking buffer and incubated on the membrane $\mathrm{o} / \mathrm{n}$ at $4^{\circ} \mathrm{C}$. Afterwards, the membrane was washed three times in TBST and incubated with the HRP coupled secondary antibody, which was diluted in the blocking buffer, at RT for one hour. After additional washing with TBST, the Enhanced Chemiluminescence Detection (ECL) solution was added according to the manufacturer's recommendations (Western Lightning $^{\mathrm{TM}}$, Western Blot Chemiluminescence Reagent Plus, PerkinElmer Life Sciences, Inc., Rodgau, Germany). Covered from day light, a photographic film was put onto the membrane and then developed in a KODAK X-OMAT developer. Exposure time varied between $10 \mathrm{sec}$ and $15 \mathrm{~min}$. To re-probe the membranes with a second primary antibody, the membrane was incubated at $60^{\circ} \mathrm{C}$ for one hour with the immunoblot stripping buffer followed by additional washing with TBST and blocking. Films were scanned in with 300 dpi using the Epson F-3200 scanner. Scanned pictures were cut using Adobe Photoshop CS3 and arranged in Adobe Illustrator. Signal intensities were measured using the gel analysis of Fiji (http://fiji.sc/). The normalized values ( \pm SEM) were shown as histograms using Microsoft Excel 2010 and p-values were calculated using the Student's t-test of Microsoft Excel 2010.

\subsubsection{RNA isolation and analysis}

\subsubsection{RNA isolation ('RNeasy mini prep')}

Small scale RNA isolation from separated corpus callosum of male mice was performed using "Qiagen's RNeasy Mini Prep" kit. The kit is based on a selective binding of RNAs bigger than 200 bases to a silica-gel based membrane under high-salt conditions, which excludes binding of $5 \mathrm{~S}, 5.8 \mathrm{~S}$ and tRNAs. RNA isolation and purification was carried out following the manufacturer's instructions. Briefly, the frozen tissue $\left(-80^{\circ} \mathrm{C}\right)$ was homogenized in Trizol (Invitrogen, Karlsruhe, Germany) with the Ultra-Turrax T8 for 30 sec. $200 \mu \mathrm{l}$ chloroform was added to $0.6 \mathrm{ml}$ homogenate, vortexed and incubated for 3 min. After $15 \mathrm{~min}$ certification at $16000 \times \mathrm{xg}$ (Heraeus Biofuge Pico table centrifuge, 13000rpm) the upper aqueous phase was transferred to a new $2 \mathrm{ml}$ Eppendorf tube. One volume of ethanol was added to the samples, mixed and applied to RNeasy columns. After 1 min centrifugation at $16000 x g$ the columns were washed one time with the RW1 
buffer and two times with the RPE buffer. RNA was eluted with $50 \mu$ of RNase-free $\mathrm{dd} \mathrm{H}_{2} \mathrm{O}$.

\subsubsection{RNA measurement with Agilent}

The quality and the amount of RNA were measured using the Agilent RNA 6000 Nano KIT and the Agilent 2100 Bioanalyzer following the company's instructions. Only RNA samples with a RNA integrity number above 8.5 were further used. The RNA concentration for all samples was adjusted to $100 \mathrm{ng} / \mu \mathrm{l}$.

\subsubsection{2. cDNA synthesis}

In order to analyze the specific RNA expression profiles, the RNA repertoire isolated from mouse tissue was converted to a complementary single stranded DNA (cDNA) library. First-strand cDNA was synthesized in a reverse transcription reaction catalyzed by RNA dependent DNA polymerase SuperScript III (Invitrogen, Karlsruhe, Germany) at 55ㄷ.

cDNA synthesis protocol:

$8 \mu \mathrm{l} \quad \mathrm{RNA}(800 \mathrm{ng}$ total)

$2 \mu \mathrm{l} \quad \mathrm{dT}$ mix Primer $(0.6 \mathrm{pmol} / \mu \mathrm{l})$

$2 \mu \mathrm{l} \quad \mathrm{N} 9$ (random nonamers $120 \mathrm{pmol} / \mu \mathrm{l}$ )

To denaturate RNA and primers, the mixture was incubated for $10 \mathrm{~min}$ at $70^{\circ} \mathrm{C}$ and $1 \mathrm{~min}$ on ice.

Afterwards the following premix was added to the reaction:

$4 \mu \mathrm{l} \quad 5 \mathrm{x}$ first strand buffer

$1 \mu \mathrm{l} \quad \mathrm{dNTP}(10 \mathrm{mM})$

$2 \mu \mathrm{l} \quad$ DDT $(100 \mathrm{mM})$

$1 \mu \mathrm{l} \quad$ SuperScript III reverse transcriptase $(200 \mathrm{U} / \mu \mathrm{l})$

The final $20 \mu \mathrm{l}$ reaction mixture was incubated in a thermocycler with the following settings:

$25 \stackrel{\circ}{ } \mathrm{C} \quad 10 \mathrm{~min}$

$50^{\circ} \mathrm{C} \quad 45 \mathrm{~min}$

$55^{\circ} \mathrm{C} \quad 45 \mathrm{~min}$

Synthesized cDNA was diluted 25 times with $\mathrm{ddH}_{2} \mathrm{O}$. 


\subsubsection{Quantitative real time PCR (qRT-PCR)}

qRT-PCR was performed using SYBR Green Master Mix according to the manufacturer's instructions (Applied Biosystems, Darmstadt, Germany). The mixture for the gene expression analysis contained $5 \mu \mathrm{l}$ of SYBR Green Master Mix, $4.8 \mu \mathrm{l}$ of cDNA (1.6 ng/ $\mu \mathrm{l})$ and $0.1 \mu \mathrm{l}$ of each primer $(10 \mathrm{pmol} / \mu \mathrm{l})$. Primers were selected with the Universal Probe Library form Roche Applied systems (https://www.roche-applied-science.com). Reactions were performed in quadruplicates. PCR reaction was carried out using following temperature conditions; $60^{\circ} \mathrm{C}$ for $1 \mathrm{~min}, 95^{\circ} \mathrm{C}$ for $15 \mathrm{sec}$ [45 cycles]. Analysis of the measurements was done with the Applied Biosystems 7500 Fast Real-Time PCR System. Results were displayed as histograms of relative RNA abundance with respect to cyclophilinA (Ppia). Diagrams and quantifications were prepared with GraphPad Prism 5. The Student's t-test was used for $p$-value quantification.

\subsubsection{Histological analysis}

\subsubsection{Teased fiber preparation}

Sciatic nerves were dissected and kept in ice cooled 1xPBS. Fine forceps (Dumont \#5 forceps, fine scientific tools) were used to remove the epineurium and to separate single axons on a glass slide. Teased fibers were dried at RT and stored at $-20^{\circ} \mathrm{C}$.

For immunohistochemistry, samples were incubated for $5 \mathrm{~min}$ with $4 \%$ [w/v] PFA and 5 min with chilled Methanol $\left(-20^{\circ} \mathrm{C}\right)$. After washing three times with 1xPBS, blocking buffer was applied for $45 \mathrm{~min}$. Primary antibodies were diluted in blocking buffer and incubated $\mathrm{o} / \mathrm{n}$ at $4^{\circ} \mathrm{C}$. The next day, excess antibody was washed off followed by incubation with the fluorophore-coupled secondary antibodies for two hours at RT. The samples were washed three times with 1xPBS, incubated with DAPI (1:10000) for 5 min and washed again. Tissue was mounted using Aqua-Poly/Mount (Polysciences, Eppelheim, Germany).

\subsubsection{Perfusion fixation of mouse tissue}

Mice were anesthetized by injection of avertin intraperitoneally $(0.2 \mathrm{ml}$ per $10 \mathrm{~g}$ of body weight). After confirming successful anesthesia by pinching the hind paw, animals were stabilized with the ventral side up. The abdomen was opened and the diaphragm was removed to expose the heart. A butterfly cannula (27G, Venofix) connected to a peristaltic pump was injected into the left ventricle, while the right atrium was cut, generating a small opening. The blood was flashed out for 4 min with warm $\left(37^{\circ} \mathrm{C}\right)$ HBSS (Invitrogen, Karlsruhe, Germany). Afterwards $40-50 \mathrm{ml}$ warm fixative was used to fix the tissue. Depending on the further use different fixatives were used. All used mice were again genotyped using a tail biopsie. 


\subsubsection{Immunohistochemistry of cryosections}

Mice were perfused using 4\% [w/v] PFA. After fixation, tissue was transferred to $10 \%[\mathrm{w} / \mathrm{v}$ ] sucrose in $0.1 \mathrm{M}$ phosphate buffer. After one hour at $4^{\circ} \mathrm{C}$, tissue was first transferred to $20 \%[\mathrm{w} / \mathrm{v}]$ sucrose and then to $30 \%[\mathrm{w} / \mathrm{v}]$ sucrose in $0.1 \mathrm{M}$ phosphate buffer, each o/n at $4^{\circ} \mathrm{C}$. Following this cryo-protective step, brain and spinal cord were frozen and stored at $20^{\circ} \mathrm{C}$. A cryostat (Leica, Wetzlar, Germany) was used to generate $20 \mu \mathrm{m}$ thick longitudinal or transverse sections of stabilized tissue, which were collected on glass slide and dried at $\mathrm{RT}$ and stored at $-20^{\circ} \mathrm{C}$. For immunofluorescent stainings, tissue was incubated with the blocking buffer for 1 hour. The primary antibodies were diluted in the blocking buffer and incubated at $4^{\circ} \mathrm{C}$ for 40 hours. Afterwards, slides were washed three times for 10 min with 1XPBS and incubated for two hours with the secondary antibodies at RT. After additional washing with 1xPBS, tissue was incubated with DAPI (1:10000) for 5 min and was washed again. Tissue was mounted using Aqua-Poly/Mount.

\subsubsection{Imaging of fluorescent stainings}

Slides were imaged with the confocal microscope Leica SP5. Signal was collected sequentially with the objective HCX PL APO lambda blue 63.0x1.20 WATER UV. An argon laser with the excitation of $488 \mathrm{~nm}$ was used to excite the Alexa488 fluorophore and the emission was set to $500 \mathrm{~nm}-560 \mathrm{~nm}$. Cy3 was excited with the DPSS561 at an excitation of $561 \mathrm{~nm}$ and the emission was set to $573 \mathrm{~nm}-630 \mathrm{~nm}$. The HeNe laser was used to excite Dyelight633 with $633 \mathrm{~nm}$ and emission was detected between $645 \mathrm{~nm}-$ $738 \mathrm{~nm}$. DAPI was excited with $405 \mathrm{~nm}$ and collected between $417 \mathrm{~nm}-480 \mathrm{~nm}$. The LAS AF lite and Fiji were used to export the images as tif-files.

\subsubsection{Detection of $\beta$-galactosidase in tissue sections (X-gal staining)}

The bacterial enzyme $\beta$-galactosidase catalyzes the cleavage of the 01 bond of the sugar $\beta$-D-galactose to a substituent. The enzyme is specific to cleave organic compounds such as 5-bromo4-chloro-3-indolyl- $\beta$-D-galactoside (X-gal) generating blue precipitate (5bromo-4-chloro-3- hydroxyindole) under oxidizing buffer conditions. Cloning this enzyme in front of regulatory element of genes and monitoring its activity in vivo, enables gene transcription analysis (Goring et al., 1987, Sanes, 1994). To detect $\beta$-galactosidase activity in Sept8_LacZ mice, $100 \mu \mathrm{m}$ vibratome sections were prepared from mouse brains previously perfused with $4 \%$ [w/v] PFA. Sections were placed in $\beta$-gal staining buffer for $1-2$ hours at $37^{\circ} \mathrm{C}$ in the dark. To stop the X-gal reaction, sections were washed in 1 XPBS three times. Finally, sections were mounted on glass slides, air-dried and cover- 
slipped with Aqua-Poly/Mount. Tissue sections were imaged using the Zeiss Axio Z1 with the Zen 2011 software (Zeiss, Oberkochern, Germany).

\subsubsection{Tissue processing using paraffin}

Mice were perfused with $4 \%[\mathrm{w} / \mathrm{v}] \mathrm{PFA}$ and post-fixed $\mathrm{o} / \mathrm{n}$ at $4^{\circ} \mathrm{C}$. For thin sectioning, brains were embedded in paraffin (Paraplast, Leica, Wetzlar, Germany) using an automated system (HMP 110, MICROM) with the following program:

$\begin{array}{ll}\text { Procedure } & \text { Time } \\ 50 \%[\mathrm{v} / \mathrm{v}] \text { Ethanol } & 1 \text { hour } \\ 70 \%[\mathrm{v} / \mathrm{v}] \text { Ethanol } & 2 \times 2 \text { hours } \\ 96 \%[\mathrm{v} / \mathrm{v}] \text { Ethanol } & 2 \times 2 \text { hours } \\ 100 \%[\mathrm{v} / \mathrm{v}] \text { Ethanol } & 2 \times 2 \text { hours } \\ \text { Isopropanol } & 1 \text { hour } \\ \text { Xylol } & 2 \times 2 \text { hours } \\ \text { Paraffin } & 2 \times 2 \text { hours }\end{array}$

Afterwards, the tissue was placed in metal forms and casted in blocks with $60^{\circ} \mathrm{C}$ warm paraffin. Labeled paraffin blocks were cooled and stored at RT. The tissue was cut in $5 \mu \mathrm{M}$ thick sections using the microtome (HM 400, MICROM) and dried at RT.

For further use, sections were deparaffinized by the following steps:

$\begin{array}{ll}\text { Procedure } & \text { Time } \\ 60{ }^{\circ} \mathrm{C} & 10 \mathrm{~min} \\ \text { Xylol } & 2 \times 10 \mathrm{~min} \\ \text { Xylol/lsopropanol }(1: 1) & 10 \mathrm{~min} \\ 100 \%[\mathrm{v} / \mathrm{v}] \text { Ethanol } & 5 \mathrm{~min} \\ 90 \%[\mathrm{v} / \mathrm{v}] \text { Ethanol } & 5 \mathrm{~min} \\ 70 \%[\mathrm{v} / \mathrm{v}] \text { Ethanol } & 5 \mathrm{~min} \\ 50 \%[\mathrm{v} / \mathrm{v}] \text { Ethanol } & 5 \mathrm{~min} \\ \mathrm{ddH}_{2} \mathrm{O} & 5 \mathrm{~min}\end{array}$

\subsubsection{Gallyas silver impregnation}

Deparaffinized $5 \mu \mathrm{M}$ brain sections were used to visualize myelin. The technique developed by Gallyas based on binding of colloidal silver particles to myelinated fibers (Gallyas, 1979). First, sections were incubated with a 2:1 mixture of pyridine and acetic anhydride for $30 \mathrm{~min}$ at RT to inhibit labeling of other tissue than myelin. Then, tissue was 
washed with $\mathrm{ddH}_{2} \mathrm{O}$ three times 10 min each, incubated in warm incubation solution for 10 min and washed with $0.5 \%[\mathrm{v} / \mathrm{v}]$ acetic acid three times for $5 \mathrm{~min}$. Afterwards, sections were incubated in the developer solution for $4 \mathrm{~min}$ and the reaction was stopped by washing in $1.0 \%[\mathrm{v} / \mathrm{v}]$ acetic acid. After additional washing with $\mathrm{ddH}_{2} \mathrm{O}$, silver staining was stabilized by incubation with $2 \%$ [v/v] sodium thiosulfate solution for $5 \mathrm{~min}$. Tissue was dehydrated by an alcohol gradient $(50 \%[\mathrm{v} / \mathrm{v}], 70 \%[\mathrm{v} / \mathrm{v}], 90 \%[\mathrm{v} / \mathrm{v}]$, and $100 \%[\mathrm{v} / \mathrm{v}]$ for 5 min each), incubated with Xylol/lsopropanol (1:1, $5 \mathrm{~min}$ ) followed by two times Xylol (5 min) and mounted using Eukitt.

\subsubsection{Immunohistochemistry of paraffin embedded tissue}

$5 \mu \mathrm{M}$ thin brain sections were used to label neuropathological markers. Deparaffinized tissue was incubated in citrate buffer for $5 \mathrm{~min}$ and then cooked for $10 \mathrm{~min}$ in boiling citrate buffer to permeabilize the tissue (650 watts in microwave oven). After cooling for about $20 \mathrm{~min}$, sections were rinsed with Tris buffer containing $2 \%[\mathrm{w} / \mathrm{v}]$ milk powder. Glass slides were placed into Shandon coverplates (Thermo Scientific, Cheshire, UK) for even distribution of solutions and rinsed again with Tris buffer containing $2 \%$ milk powder. For paraffin embedded brain sections horse radish peroxidase (HRP) coupled secondary antibodies were used. Therefore, it was necessary to inhibit the endogenous peroxidase activity by applying $3 \%[\mathrm{v} / \mathrm{v}]$ hydrogen peroxide for $5 \mathrm{~min}$. After additional washing with Tris buffer containing $2 \%[\mathrm{w} / \mathrm{v}]$ milk powder, slides were incubated in the blocking solution $(20 \%$ [v/v] goat serum in BSA/PBS) for $30 \mathrm{~min}$ at RT. Primary antibodies were diluted in $\mathrm{BSA} / \mathrm{PBS}$ and incubated $\mathrm{o} / \mathrm{n}$ at $4^{\circ} \mathrm{C}$. Subsequently, slides were washed with Tris buffer containing $2 \%[\mathrm{w} / \mathrm{v}]$ milk powder. For visualization of amyloid beta precursor protein (APP) the $\mathrm{LSAB}_{2}$ kit (Dako, Hamburg, Germany) was used. The sections were incubated with $100 \mu \mathrm{l}$ of bridging antibody i.e. a biotinylated secondary antibody for $10 \mathrm{~min}$ at RT and rinsed with Tris buffer containing $2 \%[\mathrm{w} / \mathrm{v}]$ milk powder. The HRP complex bound antibody was incubated for $10 \mathrm{~min}$ at RT. For detection of MAC-3, slides were incubated with the $\alpha$ rat-biotinylated antibody for $30 \mathrm{~min}$. Then, the Vector Elite ABC Kit (Vector Labs, Loerrach, Germany) was incubated for 30min. The coverplates were removed and all sections were rinsed with Tris buffer without milk-powder. The HRP substrate 3,3'Diaminobenzidine (DAB) was applied by using the DAB Zytomed Kit (Zytomed Systems $\mathrm{GmbH}$, Berlin, Germany) and incubated for $10 \mathrm{~min}$. Brown labeling appeared where antibodies recognized their targets. After additional washing with $\mathrm{ddd}_{2} \mathrm{O}$, sections were incubated in $0.1 \%[\mathrm{w} / \mathrm{v}]$ Haematoxylin for $5 \mathrm{~min}$ to label nuclei. Blue coloration appears due to the interaction with the basic nuclear compartment. Sections were rinsed with $\mathrm{dd}_{2} \mathrm{O}$, incubated with $\mathrm{HCl}$-Alcohol for $5-10 \mathrm{sec}$ and with Scott's solution for 5 min. This was followed by additional rinse with $\mathrm{ddH}_{2} \mathrm{O}$, the counterstaining with $0.1 \%[\mathrm{w} / \mathrm{v}]$ Eosin for 
3-5 min and another rinse with $\mathrm{dd}_{2} \mathrm{O}$. Tissue was dehydrated by an alcohol gradient $(50 \%[\mathrm{w} / \mathrm{v}], 70 \%[\mathrm{w} / \mathrm{v}], 90 \%[\mathrm{w} / \mathrm{v}]$, and $100 \%[\mathrm{w} / \mathrm{v}]$ for $5 \mathrm{~min}$ each), incubated with Xylol/lsopropanol (1:1, $5 \mathrm{~min})$ followed by two times Xylol (5 min) and mounted using Eukitt.

\subsubsection{Imaging and quantification of DAB developed stainings}

Tissue was imaged using the Zeiss Axio Z1 with the Zen 2011 software (Zeiss, Oberkochern, Germany). The quantification of MAC-3 signal was done with Fiji. First, the color threshold was used to transform the colored picture to a black and white one; brown signal represented by positive black signal. Second, the area of the positive black signal was measured and related to the size of the analyzed area. Diagrams, quantification and Student's t-test ( $p$-value) were prepared with Microsoft Excel 2010.

\subsubsection{Electron microscopy}

\subsubsection{Tissue preparation}

Optic or sciatic nerves were fixed with Karlsson-Schultz fixative to analyze myelin structure at ultrastructural level. For immunoelectron microscopy (IEM), optic nerves were fixed only for one hour in immuno-Karlsson-Schultz fixative and then stored in $1 \%[\mathrm{w} / \mathrm{v}]$ PFA.

\subsubsection{Epon embedding}

Karlsson-Schultz fixed optic or sciatic nerves for subsequent EM imaging were embedded using an automated system (EMTP, Leica, Wetzlar, Germany). Steps included osmification, dehydration and Epon impregnation. Prior to embedding, tissue was washed from the fixative with $0.1 \mathrm{M}$ phosphate buffer and placed into the plastic chambers. Chambers were then placed into the machine for embedding and tissue was processed using the following protocol: 


\section{Solution}

Phosphate buffer

$2 \%[\mathrm{w} / \mathrm{v}] \mathrm{OsO}_{4}$

$\mathrm{dd}_{2} \mathrm{O}$

$30 \%[\mathrm{v} / \mathrm{v}]$ Ethanol

$50 \%$ [v/v] Ethanol

$70 \%$ [v/v] Ethanol

$90 \%[\mathrm{v} / \mathrm{v}]$ Ethanol

$100 \%[\mathrm{v} / \mathrm{v}]$ Ethanol

Propylenoxid

Propylenoxid/Epon 2:1

Propylenoxid/Epon 1:1

Propylenoxid/Epon 1:2

Epon

\section{Incubation time}

3 times $10 \mathrm{~min}$

4 hours

3 times $10 \mathrm{~min}$

20 min

$20 \min$

$20 \mathrm{~min}$

$20 \mathrm{~min}$

4 times $10 \mathrm{~min}$

3 times $10 \mathrm{~min}$

2 hours

2 hours

4 hours

4 hours

\section{Temperature}

$4^{\circ} \mathrm{C}$

$4 \stackrel{\circ}{ } \mathrm{C}$

$4 \stackrel{\circ}{ } \mathrm{C}$

$4 \stackrel{\circ}{ } \mathrm{C}$

$4 \stackrel{\circ}{ } \mathrm{C}$

$4 \stackrel{\circ}{ } \mathrm{C}$

$4 \stackrel{\circ}{ } \mathrm{C}$

$4^{\circ} \mathrm{C}$

RT

RT

RT

RT

RT

Tissue was then placed into the labeled Epon filled molds and left $\mathrm{o} / \mathrm{n}$ at $60^{\circ} \mathrm{C}$ for Epon polymerization.

\subsubsection{Sectioning of Epon embedded optic or sciatic nerves}

Epon embedded nerves were cut using the microtome (Ultracut $S$, Leica, Wetzlar, Germany). A diamond knife (Diatome Ultra 45) was used to prepare semi-thin (300 nm) and ultra-thin $(50 \mathrm{~nm})$ sections. Semi-thin sections were collected onto a glass slide and dried on a $60^{\circ} \mathrm{C}$ hot plate. $50 \mathrm{~nm}$ sections were placed on a double sized slot grid $(2 \mathrm{~mm}$ $1 \mathrm{~mm}$, AGAR scientific, Essex, UK) coated with formvar polyvinyl and contrasted.

\subsubsection{Staining of semi-thin sections}

$300 \mathrm{~nm}$ thin sections of optic or sciatic nerves were labeled using the Methylene blueAzure II stain (Richardson et al., 1960). On a $60^{\circ} \mathrm{C}$ hot plate, sections were incubated for $1 \mathrm{~min}$ and then extensively rinsed with $\mathrm{dd}_{2} \mathrm{O}$. After drying, tissue was mounted using Eukitt and imaged with the Zeiss Axio Z1 (Zeiss, Oberkochern, Germany).

\subsubsection{Contrasting of ultra-thin sections}

Grids were placed upside-down on drops of the following solutions:

30 min Uranyl acetate (covered from daylight)

$3 \times 1$ min $\quad \mathrm{ddH}_{2} \mathrm{O}$

6 min Reynolds lead citrate

$4 \times 1 \min \quad \mathrm{ddH}_{2} \mathrm{O}$

Grids were carefully dried with a stripe of filter paper. 


\subsubsection{Analysis of EM pictures}

Ultra-thin sections were analyzed with the Zeiss EM900 (Zeiss, Oberkochen, Germany) and digital pictures were obtained using the wide-angle dual speed 2K-CCD-Camera (TRS, Moorenweis, Germany). G-ratio measurements and quantifications of myelin abnormalities were performed using Fiji. Microsoft Excel 2010 was used for diagrams and statistical tests ( $p$-value, Student's t-test). Presentation of pictures was prepared using Adobe Photoshop CS3 and Microsoft PowerPoint 2010.

\subsubsection{Immunoelectron microscopy}

Immunoelectron microscopy was performed by Dr. Wiebke Möbius and Ramona Jung. Fixed optic nerves were immersed with $2.3 \mathrm{M}$ sucrose in $0.1 \mathrm{M}$ phosphate buffer $\mathrm{o} / \mathrm{n}$, mounted onto aluminium pins for ultramicrotomy and frozen in liquid nitrogen. $50 \mathrm{~nm}$ thin cryosections were cut with the EM UC6i ultramicrotom (Leica, Wetzlar, Germany) and were picked up in a 1:1 mixture of $2 \%$ [w/v] methylcellulose and 2.3 $\mathrm{M}$ sucrose (Liou et al., 1996). Sections were blocked with $1 \%[\mathrm{w} / \mathrm{v}] \mathrm{BSA}$ in PBS. Primary antibodies were diluted in $0.1 \%$ [w/v] BSA/PBS and prepared according to (Roth et al., 1978, Slot and Geuze, 1985), incubated with the sections for $30 \mathrm{~min}$ and detected with protein A-gold (10 $\mathrm{nm}$ ). For double labeling, antibody incubation occurred sequentially: first the antibody directed against SEPT9 using protein A-gold $10 \mathrm{~nm}$ and second, the antibody directed against SEPT8 visualized by protein A-gold $15 \mathrm{~nm}$. Detailed information for the IEM methods was published previously (Werner et al., 2007). Sections were analyzed with a LEO EM912 Omega (Zeiss, Oberkochen, Germany) and digital micrographs were obtained with an on-axis 2048x2048-CCD camera (TRS, Moorenweis, Germany). Presentation of pictures was prepared using Adobe Photoshop CS3 and Microsoft PowerPoint 2010.

\subsubsection{Induction of experimental autoimmune encephalomyelitis in mice}

Experimental autoimmune encephalomyelitis (EAE) was induced in 15-week old female mice. They were immunized by sub-cutaneous injection with $200 \mu \mathrm{l}$ (bilateral injection in the inguinal and the scapular area; $50 \mu \mathrm{l}$ in each injection site) of MOG 35-55 (1.25 mg/ml) (total MOG/mouse; +/- $250 \mu \mathrm{g}$ ) emulsified in complete Freund adjuvant (CFA) (Rao and Segal, 2012). This injection was performed by the trained colleague Benoit Barrette, Ph.D. Right after the immunization and 48 hours later, $500 \mathrm{ng}$ of Pertussis toxin was injected intraperitoneally (diluted in a total volume of $300 \mu \mathrm{l}$ ). Mice were observed daily. Thereby, evaluation of EAE scores proceeded as followed: 


\begin{tabular}{|c|c|}
\hline EAE score & Symptoms \\
\hline 0.5 & loss of tail tip tone \\
\hline 1 & loss of tail tone \\
\hline 1.5 & ataxia, mild walking deficits (slipping off the grid) \\
\hline 2 & $\begin{array}{l}\text { mild hind limb weakness, less frequent walking and with obvious } \\
\text { deficits, can't stay hanging on a flipped grid, twisting of the tail } \\
\text { causes rotation of the whole body }\end{array}$ \\
\hline 2.5 & $\begin{array}{l}\text { moderate hind limb weakness, not walking by itself, but capable } \\
\text { after nudging, can't grip the grid with hind paw, but able to stay on } \\
\text { a } 90^{\circ} \text { (upright) tilted grid (water and food was added in the cage) }\end{array}$ \\
\hline 3 & $\begin{array}{l}\text { complete hind limb weakness, falls down from a } 90^{\circ} \text { (upright) tilted } \\
\text { grid }\end{array}$ \\
\hline 3.5 & hindlimb plegic \\
\hline 4 & forelimbs also affected \\
\hline 4.5 & moribund \\
\hline 5 & dead \\
\hline
\end{tabular}

For immunohistochemistry, animals were perfused with $4 \%$ [w/v] PFA, tissue was embedded in paraffin (section 3.2.4.6) and processed as described in section 3.2.4.8/9. . Diagrams and statistical tests were prepared with Microsoft Excel 2010. 


\section{Results}

\subsection{The septin cytoskeleton of central nervous system myelin}

\subsubsection{Mass spectrometric and immunoblot characterization of mature CNS myelin}

To approach the molecular basis for the biogenesis, structure and function of myelin, its protein content has recently been reinvestigated using current biochemical methods. Already in the year 1973 a protocol was established to isolate myelin from other cellular structures (Norton and Poduslo, 1973, Larocca and Norton, 2007). The method has been moderately adapted and combined with modern mass spectrometry (MS). Thereby, it was possible to newly identify many proteins in CNS myelin, and to determine their relative abundance quantitatively (Jahn et al., 2009, de Monasterio-Schrader et al., 2012, Jahn et al., 2013).

To control for myelin enrichment, brain lysates and purified myelin were compared by immunoblot (Fig. 4A). As expected PLP and CNP, two myelin markers exclusively expressed by oligodendrocytes in the brain, were strongly enriched in the myelin fraction. In contrast, axonal markers such as neurofilament light chain and beta-3-tubulin were diminished. Notably, axonal marker proteins were not entirely absent from the myelin fraction, reflecting that biochemical fractions are never pure. In the applied quantitative MS of myelin performed by Dr. Stefan Tenzer, Institute for Immunology University Mainz, abundant axonal proteins might thus be detected as low-abundant contaminants.

Several members of the septin protein family were found by MS as abundant in the myelin fraction and were further analyzed by immunoblot. Three of them, namely SEPT2, SEPT4 and one isoform of SEPT8 were enriched in the myelin fraction (Fig. 4B). SEPT7 and SEPT9 were detected at about equal intensity in lysate and myelin. SEPT11 was diminished in myelin compared to brain lysate, but nevertheless detectable.

For quantitative MS, myelin was purified from C57BL/6N mouse brains ( $n=9)$. In three individual experiments SEPT2, SEPT4, SEPT7 and SEPT8 were detected as abundant proteins. For comparison, MAG was five times more abundant than SEPT8. SEPT9 was detected, but below the set threshold. SEPT11 was detected as very abundant in one experiment out of three. As seen in Fig. 4B, SEPT11 was very abundant in brain lysate and strongly reduced in myelin suggesting that SEPT11 might have been detected as false positive.

Fig. 4C shows a quantitative evaluation of the septins reliably detected in myelin. SEPT8 was the most abundant septin in CNS myelin and was set to $100 \%$ for comparison. The 
abundance of SEPT7 was determined to be about $80 \%$ compared to SEPT8. SEPT2 and SEPT4 were about $40 \%$ and $50 \%$ as abundant as SEPT 8 respectively.

Myelin from PLP and CNP mutant mice was purified and compared to controls by quantitative MS. The abundance of SEPT8 was found to be reduced to about $50 \%$ in both mutants, whereas that of SEPT2 was reduced to $50 \%$ in PLP ${ }^{\text {null }}$ and to $70 \%$ in CNP $^{\text {null }}$ myelin. In contrast, the abundance of SEPT4 and SEPT7 was reduced to $30 \%$ and $50 \%$ in CNP $^{\text {null }}$ myelin respectively, while in PLP ${ }^{\text {null }}$ myelin the abundance of SEPT4 was reduced to only $75 \%$ and SEPT7 to $50 \%$. Taken together, PLP ${ }^{\text {null }}$ and CNP ${ }^{\text {null }}$ mutant myelin display a principally reduced abundance of septins in CNS myelin. Both of these mutants display myelin abnormalities and axonal pathology (Griffiths et al., 1998, Lappe-Siefke et al., 2003). Here, we asked if the altered septin abundance is a relevant pathological aspect of the observed CNS pathology in these mutants. 
A

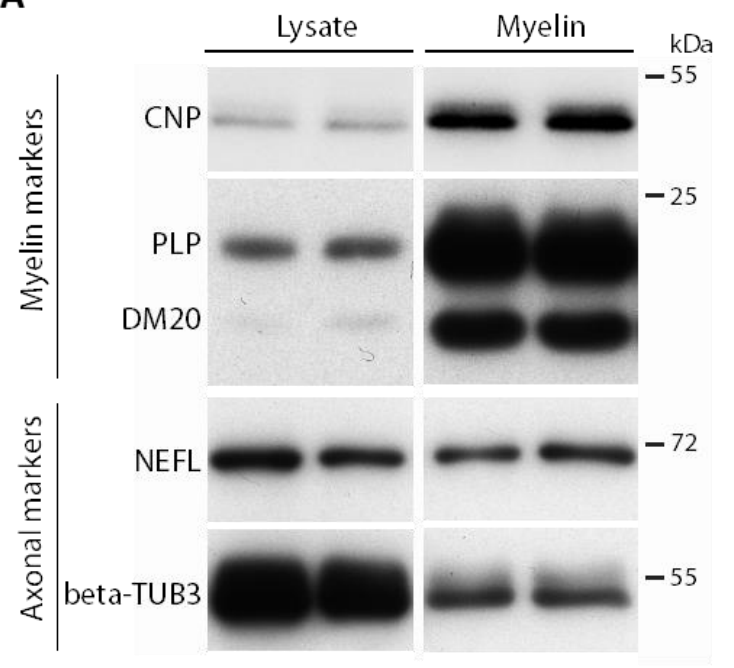

$\mathbf{B}$

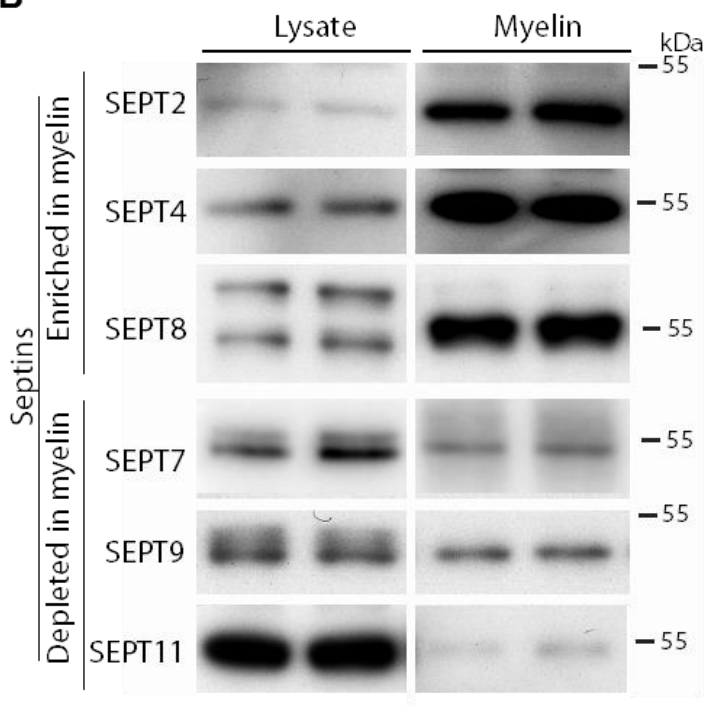

C

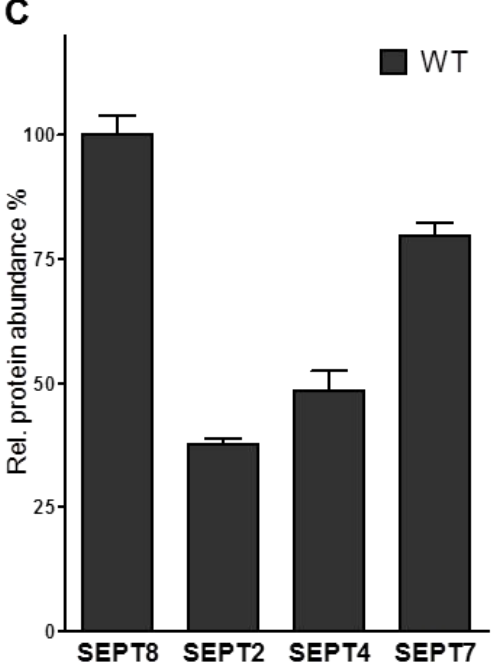

D

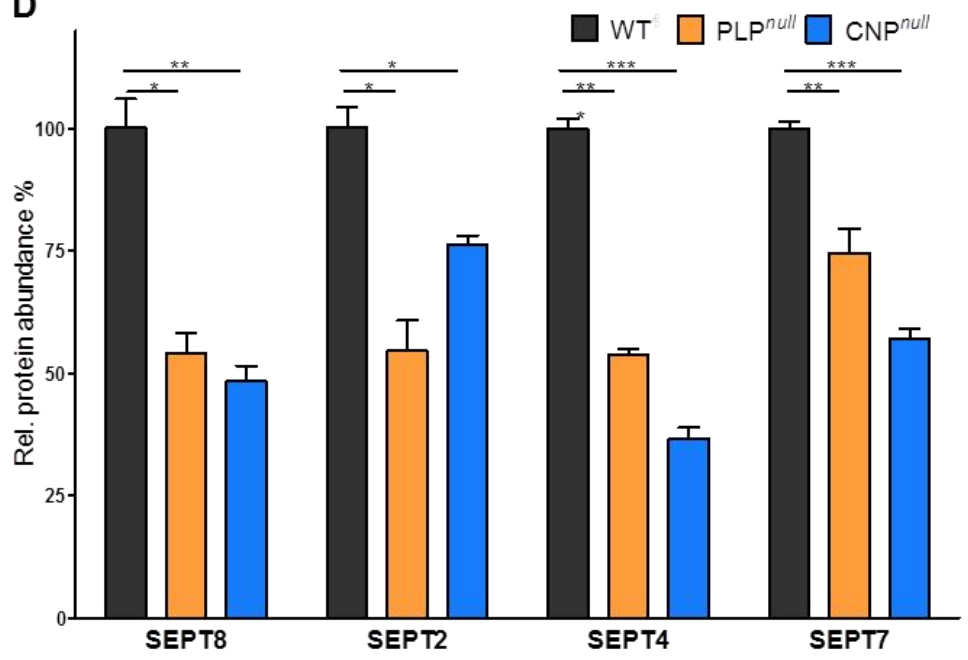

Fig. 4. Biochemical characterization of CNS myelin. A Myelin purified from mouse brains was compared to brain lysates by immunoblot analysis. Myelin proteins as CNP and PLP were enriched in the myelin fraction whereas axonal proteins as neurofilament and beta-3-tubulin were diminished. B Several members of the septin protein family were identified as abundant in myelin. SEPT2, SEPT4 and one isoform of SEPT8 were enriched, whereas SEPT7, SEPT9 and SEPT11 were of about equal abundance or diminished in the myelin fraction. C Quantitative MS was used to determine the relative abundance of septins in the myelin fraction. SEPT2, SEPT4, SEPT7 and SEPT8 were reliably identified in three independent experiments and compared to each other (C, error bar: SEM). D Myelin purified from CNP ${ }^{\text {null }}$ (blue) and PLP ${ }^{\text {null }}$ (orange) mice was compared to control by quantitative MS. In myelin of both mutant mouse lines, the abundance of septins was reduced to about $50 \%$ (error bar: SEM, ${ }^{*} p<0.05,{ }^{* *} p<0.01,{ }^{* * *} p<0.001$ ). 


\subsubsection{Subcellular localization of septins in mature CNS myelin}

By biochemical analysis, septins were found to be very abundant constituent of CNS myelin. This made it interesting to determine the localization of these newly identified myelin proteins. Using fixed optic nerves of adult mice, immunoelectron microscopy (IEM) was performed to identify the exact localization of SEPT8. As shown in Fig. 5A, gold particles labeling SEPT8 were exclusively associated with adaxonal myelin, the oligodendroglial compartment closest to the axon. Gold particles were not distributed equally, as seen in transverse sections (Fig. 5A right). Some sectioned adaxonal myelin compartments did not show any labeling while others were labeled only on one side.

To elucidate the localization of myelin septins in relation to known myelin markers, double immunohistochemistry was performed on cryosections of mouse spinal cord. The ventral spinal cord contains very large axons, allowing a good resolution by confocal microscopy. The myelin protein MAG is a known marker of the adaxonal myelin membrane (Trapp and Quarles, 1982, Trapp et al., 1989). It was labeled intensely all around the axons (Fig. 5B). SEPT8 was localized to MAG-positive structures, confirming its adaxonal localization. However, SEPT8 labeling was restricted to a punctate-appearing subdomain. Together, SEPT8 labeled a novel subdomain of the adaxonal myelin compartment.

Confocal stacks were taken from fluorescent immunohistochemical stainings of longitudinal sections of spinal cord (Fig. 6A and B). Using Imaris Software, it was possible to reconstruct 3-dimensional images with planes of a voxel depth of $130 \mathrm{~nm}$ and a voxel width/height of $40 \mathrm{~nm}$. In Fig. $6 \mathrm{~A}$ every $5^{\text {th }}$ plane is shown (distance of 5 times $130 \mathrm{~nm}$ ). A filament-like assembly of SEPT8 was observed gently undulating around the axon (Fig. $6 \mathrm{~A}$ and $\mathrm{B})$. The filament-like domains varied in length and reflected the distribution of SEPT8 in transverse planes, as observed in both the spinal cord and the optic nerve.

To better define the longitudinal organization of the SEPT8-positive domain, co-labeling experiments were performed of SEPT8 with known markers of various axonal segments (Fig. 6C and D). The nodes of Ranvier are flanked by the paranodal loops of non-compact myelin. This segment was labeled with antibodies specific for Caspr, an axonal protein connected to the paranodal loops (Einheber et al., 1997). SEPT8 was never found in close relation to Caspr (Fig. 6C). Additionally, SEPT8 was co-labeled with Kv1.2, thus labeling the potassium channels in the juxtaparanodal segment (Wang et al., 1993). SEPT8-labeling was found in close proximity to Kv1.2-labeling, thus identifying the SEPT8-positive domain as extending from the internodal into the juxtaparanodal segment (Fig. 6D). 


\section{A}
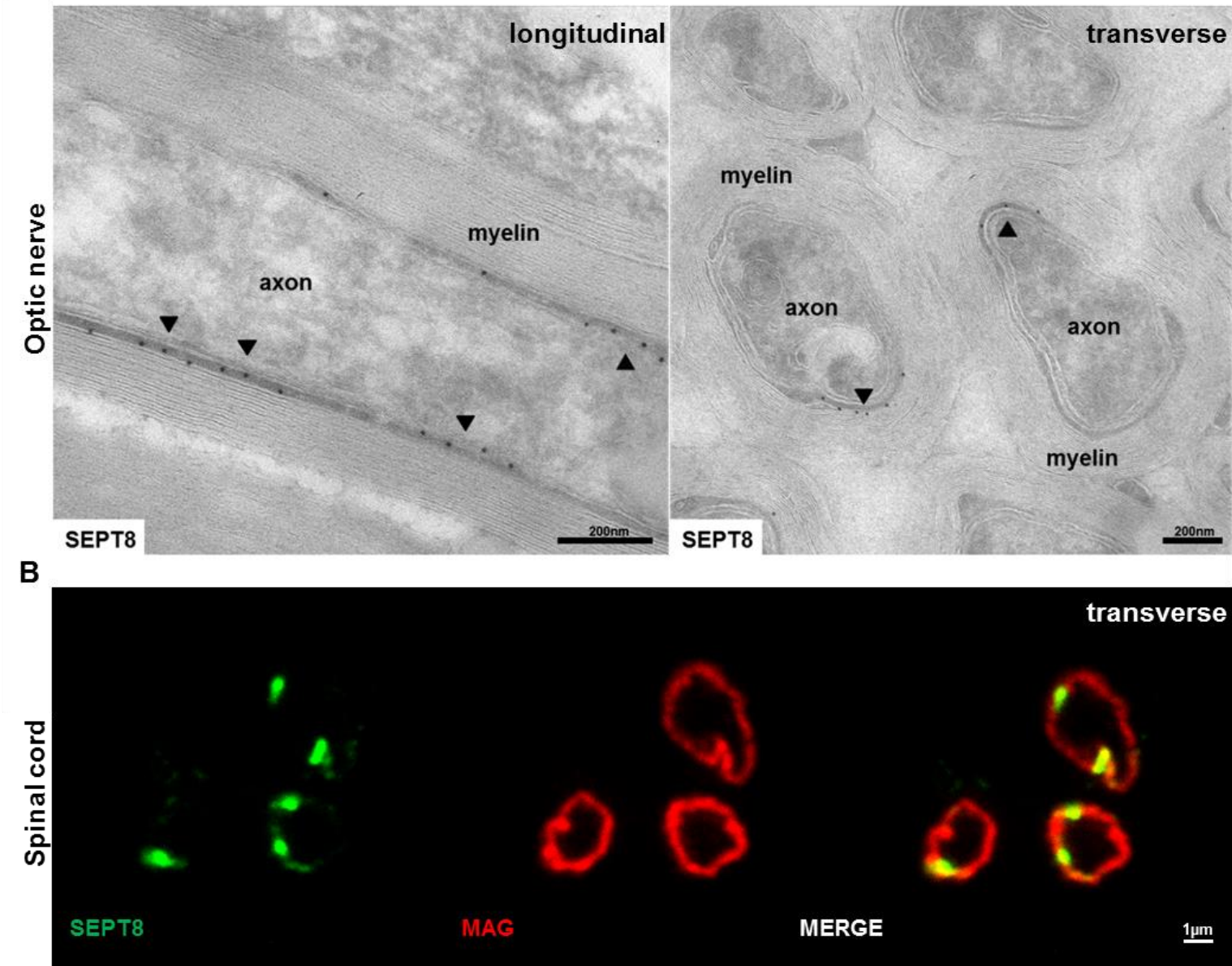

Fig. 5. Septins localize to adaxonal CNS myelin. A SEPT8 was visualized by immunoelectron microscopy in optic nerves of wild type mice. In myelin, gold particles were restricted to the adaxonal subcompartment. In transverse sections, it was apparent that SEPT8 was not equally distributed but often confined to one side of the axon. Labeling and pictures were prepared by Dr. Wiebke Möbius (Neurogenetics, MPI Exp.Med. Göttingen). B SEPT8 (green) and MAG (red) were labeled in the ventral white matter of the spinal cord. Antibodies specific for MAG labeled the entire adaxonal myelin compartemnt, while SEPT8 was restricted to one to three punctae, which clearly co-labeled with MAG. 
A

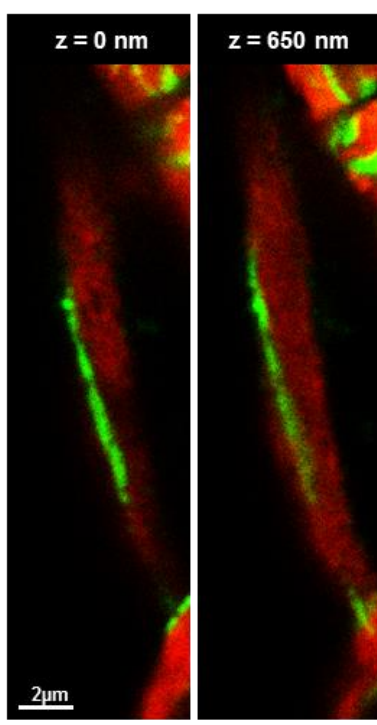

C

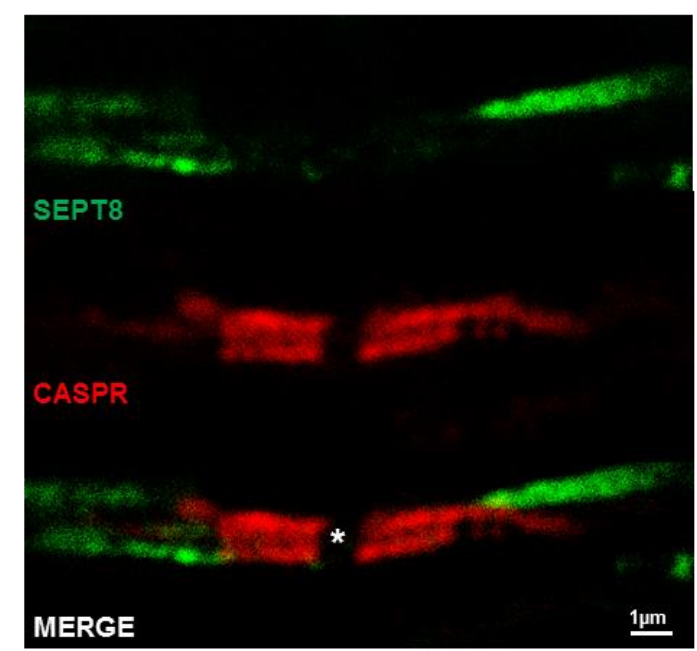

B
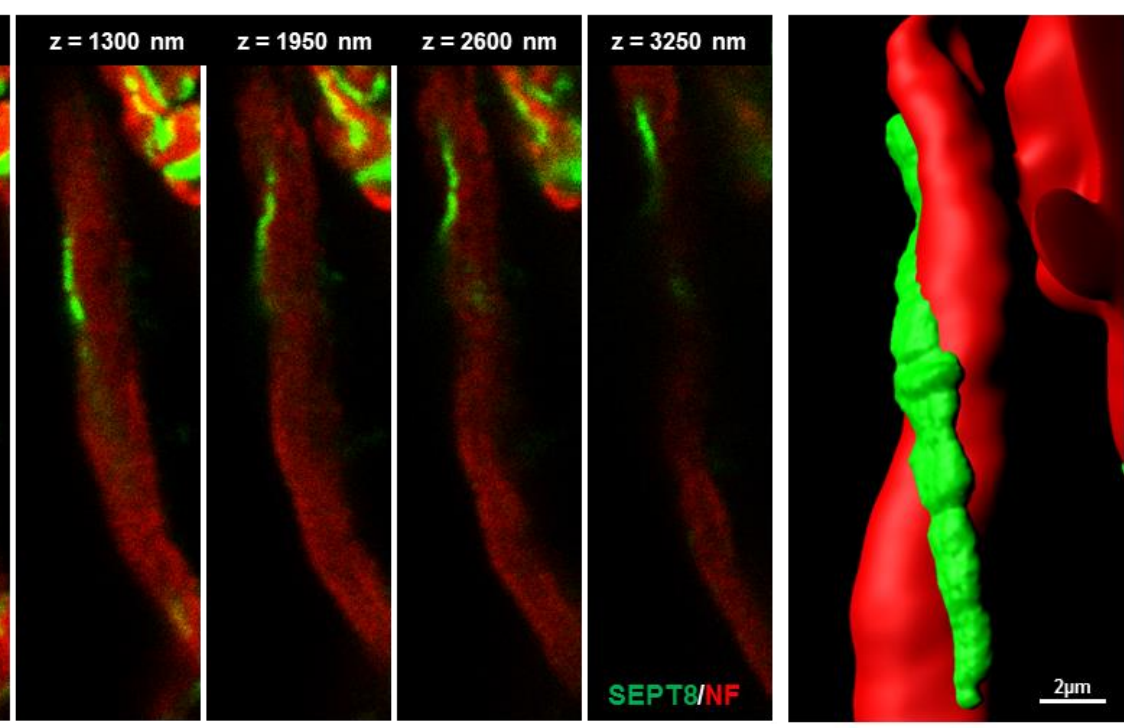

D

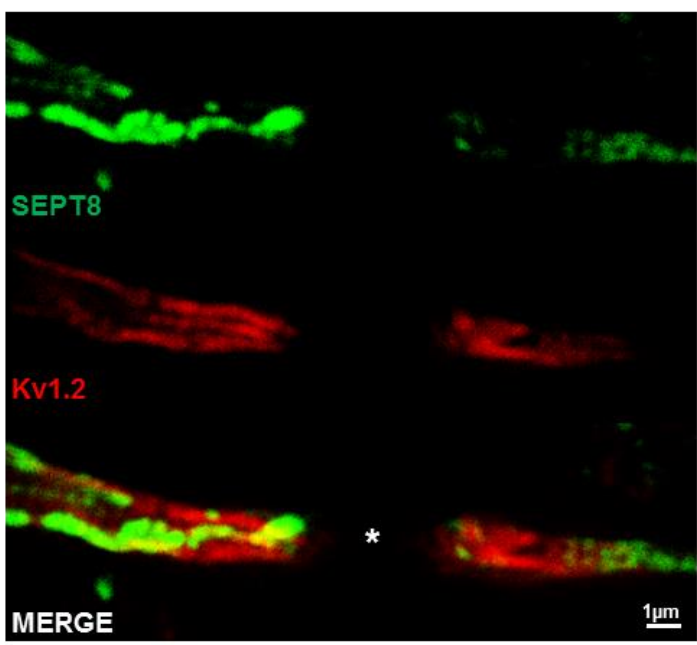

Fig. 6. Septins localize to an internodal, adaxonal myelin subcompartment. A and B A confocal stack was taken and every $5^{\text {th }}$ sectional plane is shown (A). SEPT8 (green) formed an about $10 \mu \mathrm{M}$ long rod gently undulating along the axon (red). This confocal stack was transformed in a 3-dimensional reconstruction with the Imaris software (B). C and D The localization of SEPT8 was analyzed in relation to the node of Ranvier $\left(^{*}\right)$. When the paranodal segments were marked using antibodies specific for Caspr (C, red), no co-labeling with SEPT8 was found. In contrast, SEPT8 was detected in the juxtaparanodal segment marked by potassium channels (D, red). SEPT8-labeling is in agreement with filament-like domains in the adaxonal internodal myelin compartment, extending to the juxtaparanode but not the paranode. 
To test if myelin septins display similar localizations, immunohistochemistry was applied to spinal cords and optic nerves. Exemplified with SEPT9, other myelin septins displayed the same punctate labeling as SEPT8 (Fig. 7A). Indeed, SEPT9 co-labeled with SEPT8 according to IEM (Fig. 7B), in which both septins were co-distributed in close proximity in the adaxonal internodal myelin.

Taken together, a novel domain was identified in the adaxonal internodal myelin compartment that was specifically defined by the localization of a distinct set of septins. SEPT8 was not detected in the paranodal loops, reflecting a specialization of the different segments of non-compact myelin.

A

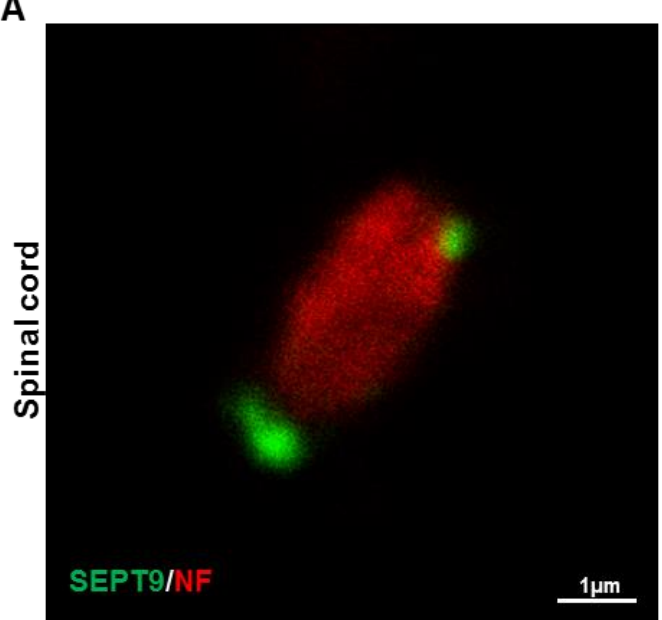

B

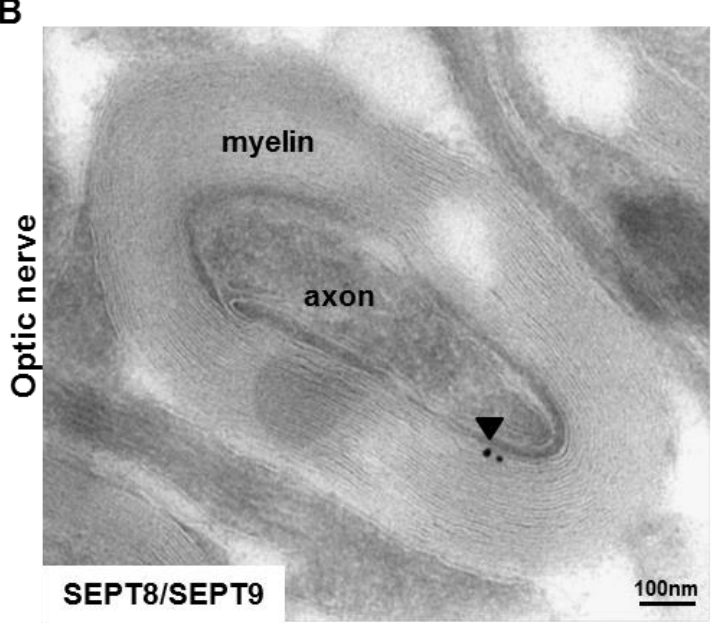

Fig. 7. The localization of SEPT9 in myelin is similar to that of SEPT8. A SEPT9 (green) was labeled in a transverse section of the spinal cord. Similar to SEPT8-labeling, SEPT9-labeling in transverse sections appeared punctate and was restricted to adaxonal myelin. Neurofilaments were labeled in red; no SEPT9 was detected within the axon. B By immunoelectron microscopy, double-visualization of SEPT8 (large black puntca, constituted by $15 \mathrm{~nm}$ gold particles) and SEPT9 (small black puntca, constituted by $10 \mathrm{~nm}$ gold particles) was performed. Septins localized together in adaxonal myelin (arrow head). IEM co-labeling and pictures were prepared by Ramona Jung (Neurogenetics, MPI Exp.Med. Göttingen). 


\subsection{Targeted loss of septins from oligodendrocytes}

\subsubsection{Generation of mice lacking SEPT8}

To test the functional requirement of myelin septins and the novel domain that they constitute for myelin stability and axonal integrity, mice lacking SEPT8 conditionally or constitutively were generated.

Embryonic stem (ES) cells harboring an engineered Sept8-allele were acquired from the European Conditional Mouse Mutagenesis Program (EUCOMM) and injected into blastocysts to generate genetically engineered mice. The gained knock-in allele contained a LacZ containing cassette, which was used to analyze the cellular expression of the Sept8 gene. Sagittal brain sections were applied to $\beta$-galactosidase histochemistry (Fig. $8 \mathrm{~A})$. Sept8 was strongly expressed in the cortex, the hippocampus and the cerebellum in a pattern suggesting neuronal expression. The white matter of the brain was also stained. Here, positive cells were found in a chain-like distribution in agreement with oligodendrocytic expression.

Since the role of SEPT8 in oligodendrocytes was to be analyzed, conditional deletion of Sept8 was necessary to not affect its possible neuronal function. First, the lacZ/neo cassette was removed by in vivo recombination using the Flp recombinase. This led to mice, in which exon 2 of the Sept8 gene was flanked by loxP sites. Secondly, Cre recombinase, expressed under control of the Cnp1-promotor (Lappe-Siefke et al., 2003), was used to remove exon 2 of the Sept 8 gene in vivo, thereby abolishing the expression of any SEPT8 isoform in oligodendrocytes (Fig. 8B). Primers for genotyping PCRs were selected to identify mice positive for the Sept8 allele harboring the loxP sites and/or to detect the deletion of exon 2 (Fig. 8B). The PCR amplicon of the loxp-site flanked allele was, as expected, about 100bp larger than that of the wild type allele (Fig. 8C). In conditional knock-out mice and in constitutive knock-out mice the deletion of exon 2 was visualized by a smaller amplicon of about $250 \mathrm{bp}$. 
A

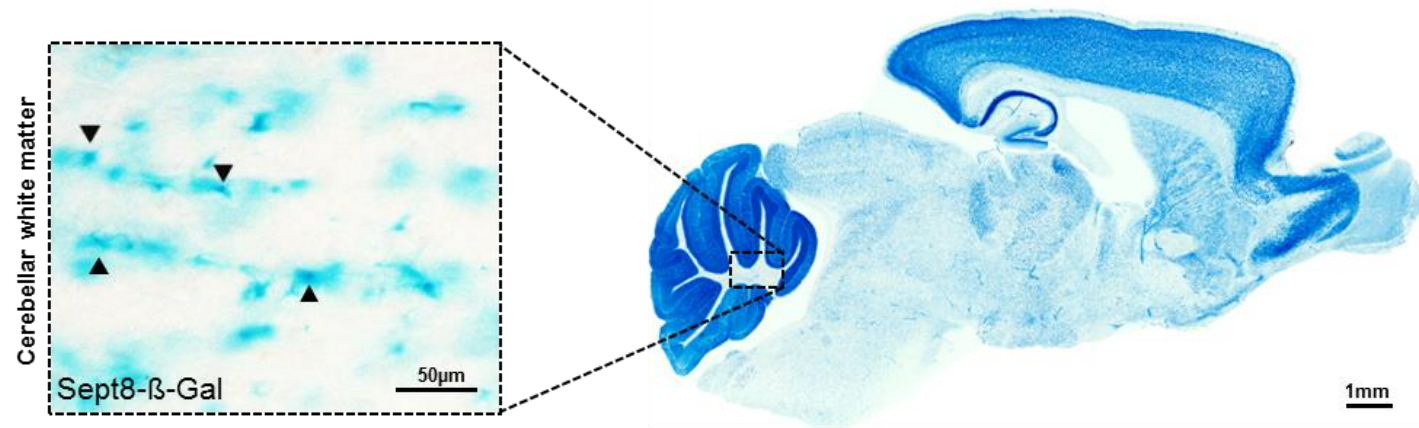

B

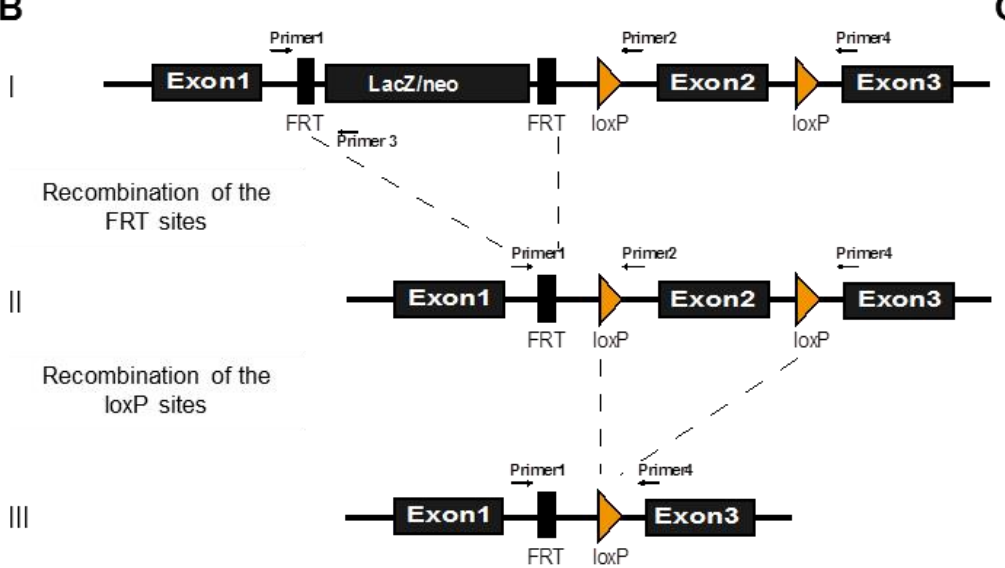

C

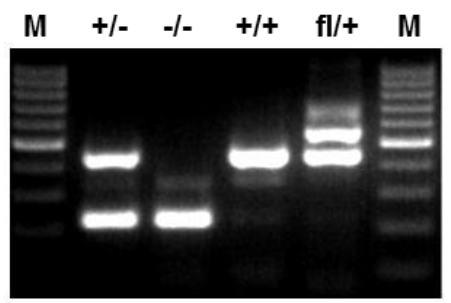

Fig. 8. Generation of mice harboring altered alleles of the Sept8 gene. A The modified Sept8 allele containing a LacZ cassette was used to analyze Sept8 gene activity. Gene activity was marked by the blue reaction product of the $\beta$-galactosidase histochemistry. The Sept8 gene was strongly active in the grey matter of the cortex, the hippocampus and the cerebellum. The enlargement shows that presumptive oligodendrocytes were labeled in the white matter as exemplified for the cerebellum. B By flippase-mediated recombination of FRT sites in vivo, the lacZ cassette was removed from the Sept8 allele (step I to II), and then exon 2 was removed by Cre recombinase activity at loxP sites (step II to III) C The various Sept8 alleles were identified by PCR.

To determine if indeed expression of SEPT8 was disrupted in SEPT8 mutant mice, and as a control for the results presented in section 1.2, immunohistochemistry with antibodies specific for SEPT8 was performed using spinal cords of control mice (WT) and conditional SEPT8 mutants (Sept ${ }^{f / / f t}{ }^{*} C n p 1^{\text {cre/wt }}$, COND) at the age of P75. In control mice, SEPT8 punctae localized to the MAG-positive compartment, reflecting its adaxonal localization. In the spinal cord, SEPT8 was never found together with an axonal marker (neurofilament, NF). Thus, SEPT8 was undetectable in axons of the spinal cord. In the conditional mutants of SEPT8 (COND) hardly any signal was detected. Only some faint signal could be seen in very small cellular processes (Fig. 9A). 

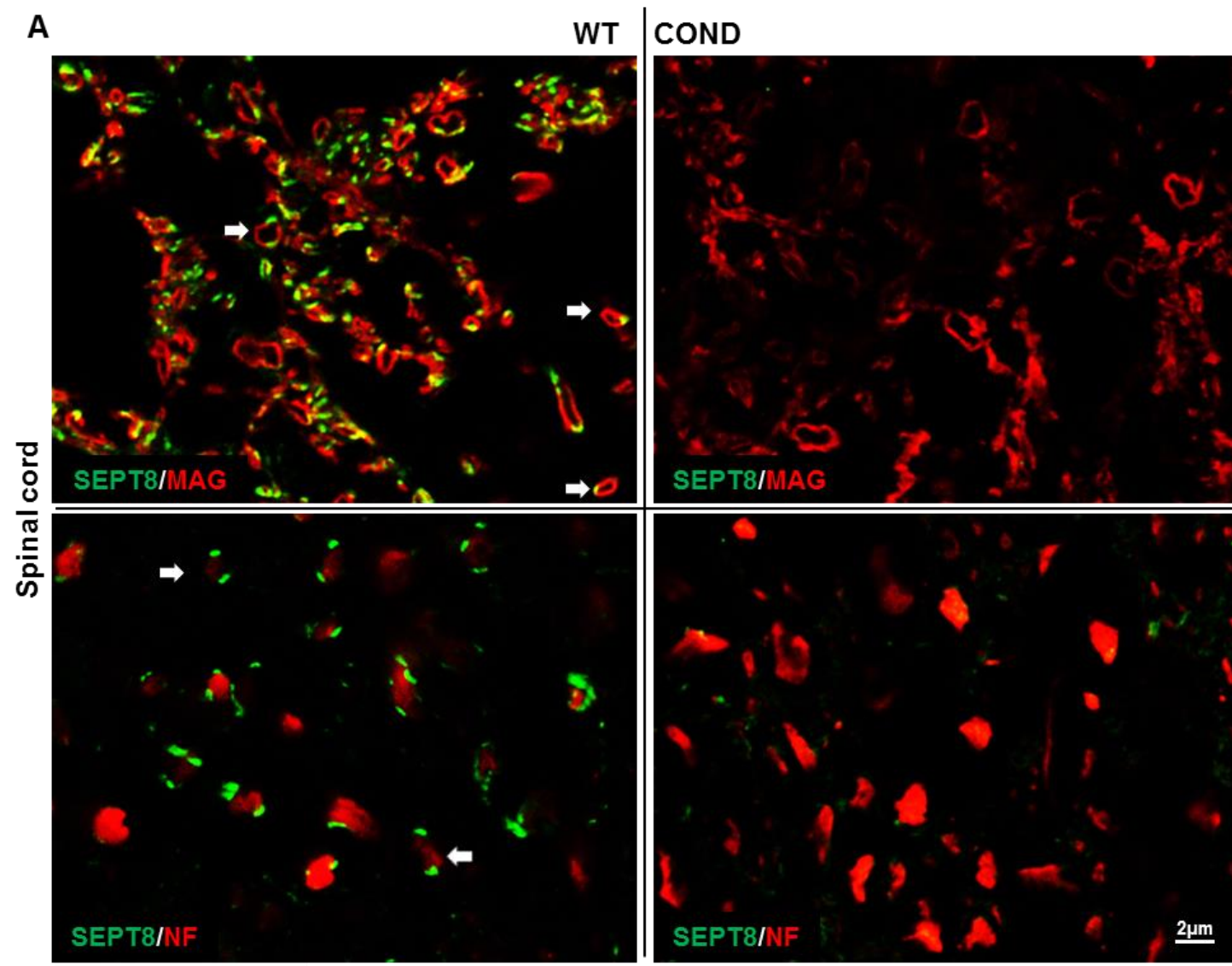

B

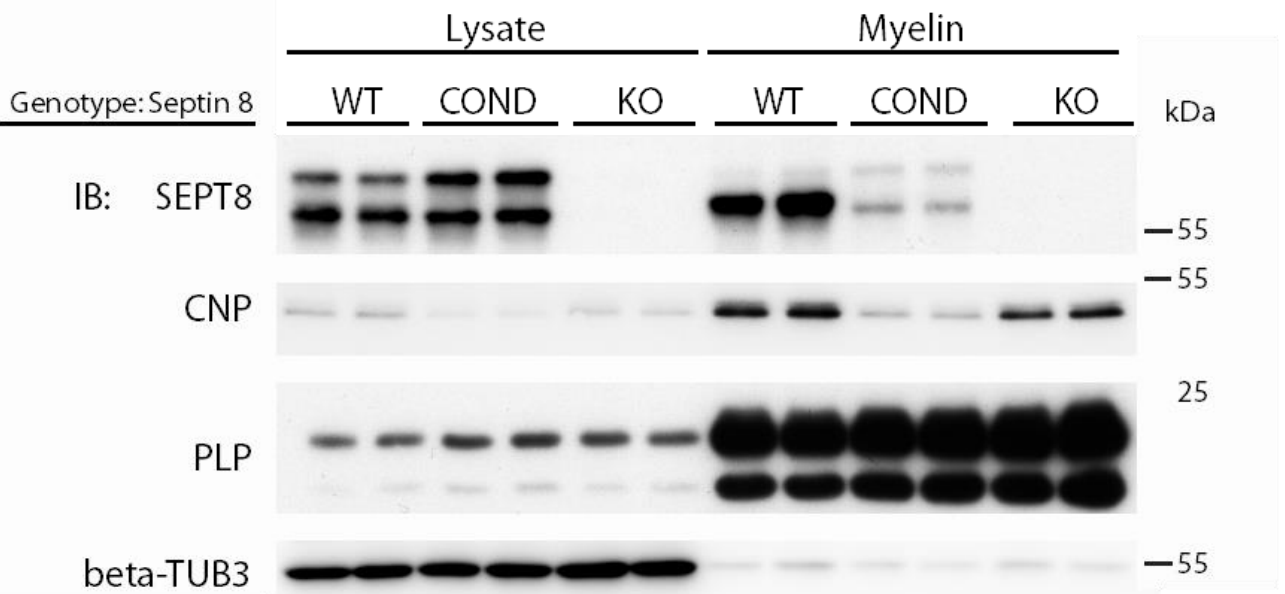

Fig. 9. Deletion of SEPT8-expression from oligodendrocytes. A Immunohistochemical analysis of the ventral white matter on transverse sections of spinal cord. Control mice (WT) showed punctae (arrows) of SEPT8 labeling (green) in the adaxonal myelin labeled by MAG (red). These domains were lateral to the axons and never co-localized with neurofilaments (NF, red). In conditional SEPT8-mutants (COND), lacking SEPT8 specifically from oligodendrocytes, almost no green signal was detectable in white matter tracts. B Immunoblots confirmed the loss of SEPT8 in brain lysates and myelin. Conditional SEPT8-mutants (COND) showed a clear loss of SEPT8 in the myelin fraction while constitutive mutants (KO) were devoid of SEPT8. The abundance of CNP was reduced in conditional mutants (COND) due to the $C n p 1^{\text {cre/wt }}$ genotype inferred by the Cre driver line.

To determine if the abundance of myelin septins is affected by the absence of SEPT8, immunoblot analyses were performed using brain lysate and myelin purified from mouse 
brains at the age of P75 (Fig. 9B). Control mice (WT) were compared to conditional mutants (Sept $8^{f / f t *} \mathrm{Cnp} 1^{\text {cre/wt }}$, COND) and to constitutive mutants (Sept $8^{-/}, \mathrm{KO}$ ). Comparing the SEPT8-specific bands detected in brain lysates of WT to COND, no decrease in the two most abundant isoforms of SEPT8 was observed. A very faint band migrating just above the smaller isoform was not detected in the COND brains. In the KO brains all SEPT8-specific signal was absent, confirming the successful deletion of SEPT8. Myelin was purified and compared to brain lysates. In WT myelin, only one band was visible, which was absent from COND and KO mice. This band likely represents the mediumsized isoform of SEPT8. In the myelin fraction of COND some signal was present, which replicated the same pattern as seen in the brain lysates. This signal in the myelin fraction of COND likely reflects contaminants in the myelin fraction. In myelin of $\mathrm{KO}$ no signal could be detected, confirming both, the successful gene targeting and the specificity of the antibodies.

The abundance of CNP was determined in lysate and myelin comparing control (WT) and mutant mice (COND, KO). As expected, CNP was always enriched in the myelin fraction. Comparing COND to WT and KO, the abundance of CNP was reduced in lysate and myelin because the Cre recombinase was knocked-in the native Cnp1 gene leading to heterozygous expression of CNP (Lappe-Siefke et al., 2003). Myelin purification was also confirmed by the increased abundance of the myelin marker PLP and the diminished abundance of the axonal marker beta-3-tubulin (Fig. 9B).

In summary, it was shown that the use of the EUCOMM ES cells and the following in vivo recombination using the Cnp1 promoter-driven expression of Cre recombinase facilitated the absence of SEPT8 in mice, in particular from CNS myelin. This was confirmed by immunohistochemistry and immunoblot. Within the white matter of the spinal cord, SEPT8 was mainly detected in oligodendrocytes, reflected by the loss of almost all signal in COND mice and the absence of detectable signal in axons. In brain, other cells additional to oligodendrocytes express SEPT8, likely neurons. 


\subsubsection{SEPT8 is essential for the presence of the septin filament in CNS myelin}

After the successful deletion of SEPT8-expression, the abundance of potentially interacting septins was tested by immunoblot (Fig. 10A). Several septins, which were previously identified to be present in myelin by MS, were strongly diminished in the myelin of COND and KO when compared to WT. SEPT2, SEPT4 and SEPT7 were reliably detected in CNS myelin of control brains, but could hardly be detected in SEPT8 mutants. When SEPT8 was missing from oligodendrocytes, SEPT9 (40kDA isoform) was also diminished. Conversely, the abundance of SEPT11 in myelin was unchanged when SEPT8 was deleted.

To identify all molecular changes in the myelin of SEPT8 deficient mice, myelin of WT and $\mathrm{KO}$ (3 probes each) were compared using quantitative mass spectrometry (Fig. 10B). No increased abundance of any protein has been detected comparing WT and KO. The abundance of only 10 proteins was significantly reduced in SEPT8-deficient myelin, 5 of them to below the set threshold of $50 \%$. As expected, SEPT8 could not be detected due to the genetic deletion. In accordance with the immunoblots (above), SEPT2 and SEPT4 were almost completely lost and SEPT7 was decreased to about $20 \%$. In addition, one new interesting candidate was identified, namely anillin. The abundance of anillin was also strongly reduced to about $10 \%$. Thus, SEPT8 was found to be essential for the presence of several other septins and of anillin in CNS myelin.

To understand if the reduced abundance of several septins in myelin of SEPT8 deficient mice is due to gene regulation or a post-transcriptinal cause, mRNA abundance was analyzed by qRT-PCR (Fig. 10C). To enrich for oligodendrocytes, corpus callosi of mouse brains were dissected and mRNA was isolated. Control mice (WT) included Sept $8^{\text {wtwt }}$ and Sept $8^{f / f t}{ }^{*} \mathrm{Cnp} 1^{\mathrm{wt} / \mathrm{wt}}$ mice. mRNA abundance of Sept8 was decreased to about $30 \%$ in COND compared to WT. The remaining Sept8 mRNA was likely the product of cells other than oligodendrocytes since the prepared corpus callosum also contains astrocytes, microglia and few cortical neurons. The mRNA abundance of Sept2, Sept4, Sept7, Sept9 and Anln was tested. The abundance of none of the corresponding mRNAs was altered in COND mice. This suggested that the loss of septins in CNS myelin of SEPT8 deficient mice was due to a post-transcriptional cause. 
A

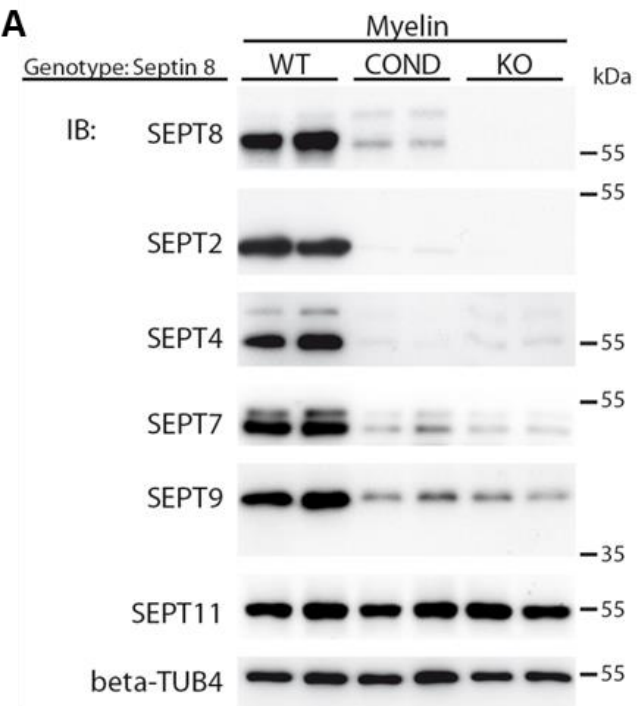

C

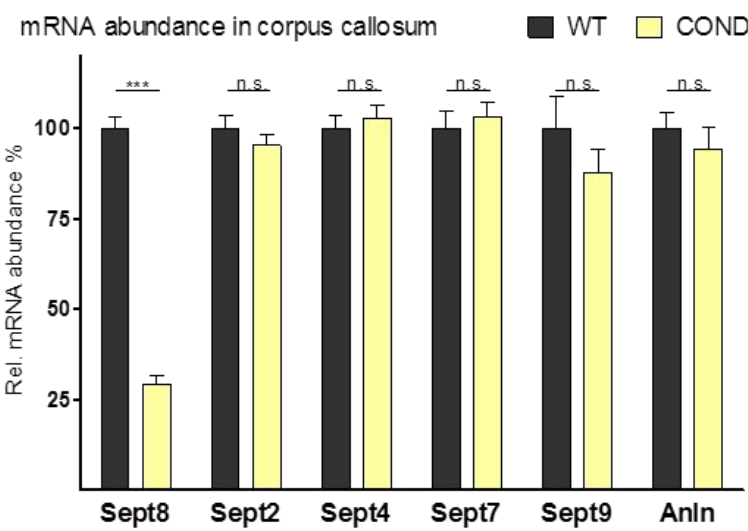

B

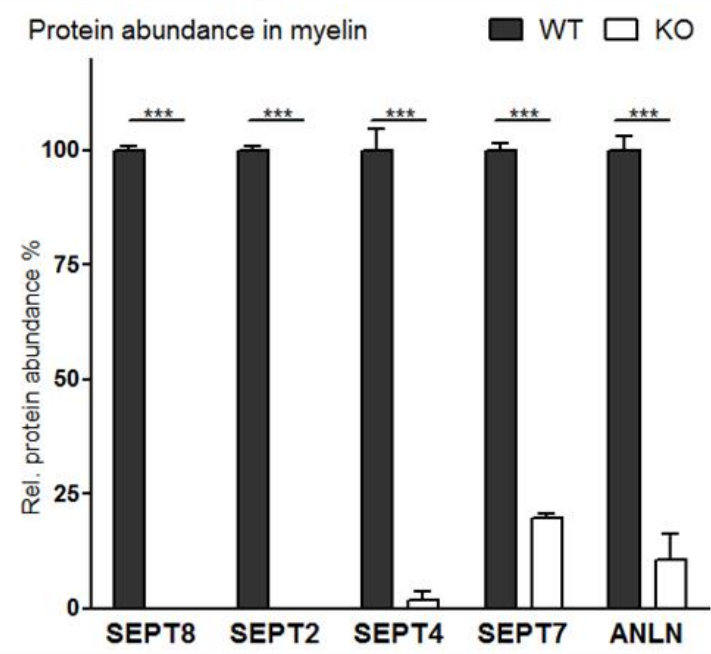

D

Fig. 10. Post-translational loss of myelin septins when SEPT8 is lacking. A Protein abundance in SEPT8-deficient myelin was compared to controls. SEPT2, SEPT4, SEPT7 and SEPT9 were readily detected in control myelin (WT), but were strongly diminished in conditional (COND) and constitutive (KO) mutant myelin. In contrast, the abundance of SEPT11 was unchanged. B Quantitative mass spectrometry was performed to compare control (WT, $n=3$ ) and constitutive myelin $(K O, n=3)$. Only 5 proteins were found to be decreased to an abundance of below $50 \%$, namely the myelin septins and a known protein to interact with them, anillin (error bar: SEM, $\left.{ }^{* * *} p<0.001\right)$. C qRT-PCR analysis of mRNAs encoding septins and anillin. In the corpus callosum of WT and COND (each $n=4$ ), only Sept8 mRNA was changed due to the genetic modification, indicating that the observed protein abundance changes were due to alterations at the post-transcriptional level (error bar: SEM, ${ }^{* * *} p<0.001$ ). D The abundance of septins was analyzed in brain lysates and myelin purified from SEPT4 deficient mice. The abundance of SEPT2 was found to be about doubled, while the abundance of SEPT8 was unchanged. 
Since SEPT8 was required for other septins to be present in the CNS myelin, we aimed to test, if all septins affect each other equally. SEPT4-deficient mice (Kissel et al., 2005) were available from H.Steller (NewYork). Comparing control mice (WT) and constitutive mutant mice of SEPT4 (KO) by immunoblot, it was found that the abundance of SEPT2 was about doubled in SEPT4 deficient myelin (Fig. 10D). This change was also apparent in the brain lysate. In contrast, the abundance of SEPT8 was unchanged in SEPT4 mutants. The loss of SEPT4 did thus not lead to a loss of septins in CNS myelin. CNP was used here as a loading control and to validate myelin enrichment. Immunoblot experiments were performed with technical support by the bachelor student Nicole Bartsch.

Taken together, SEPT8 was deleted from CNS myelin of mice and here it was shown that this led to the additional loss of all abundant myelin septins. Hence, it was hypothesized that SEPT8-deficient mice could be used to study the functional requirement of septin filaments in adaxonal myelin.

\subsubsection{SEPT8 deficient mice - development and behavior}

Conditional and constitutive SEPT8-mutants were observed from birth up to an age of one and a half years. Mutants of both genotypes were born in Mendelian ratio and developed normally. Pups grew as control littermates; they were never smaller or died prematurely. Constitutive males and females reproduced well and produced normal sized litters. The weight of the animals was compared at four months and one year of age (Fig. 11A). Young adult conditional (COND) and constitutive mutants (KO) had the same weight as the controls (WT). At one year of age WT and COND mice equally gained weight. Conversely, KO mice gained less weight and were significantly lighter than WT and COND at one year of age. KO mice gained about $17 \%$ less weight, which may hint to a role of SEPT8 in the metabolism of mice. The loss of SEPT8 from oligodendrocytes did not lead to apparent impairments affecting the weight of mice.

Conditional and constitutive SEPT8 mutants were subjected to coordination motor behavior tests. The elevated beam test was used (Brooks and Dunnett, 2009). In this task mice walk over a narrow beam and hind limb slips are counted (Fig. 11B). This test was performed with 6 animals per genotype at the age of half a year and repeated at one year. Mice of all genotypes showed a high variability and did not differ significantly at either time point. Coordination and motor performance was thus not impaired when SEPT8 was deleted. 
Comparing SEPT8 mutants to controls, the overall brain morphology was analyzed (Fig. 12). The Gallyas silver impregnation method was used to visualize myelin (Gallyas, 1979). The brains of all genotypes and ages were equal in size and structure. The amount of myelin appeared equal. The loss of SEPT8 and the interacting septins in myelin did thus not impair the general development of myelin or the brain.

\section{A}
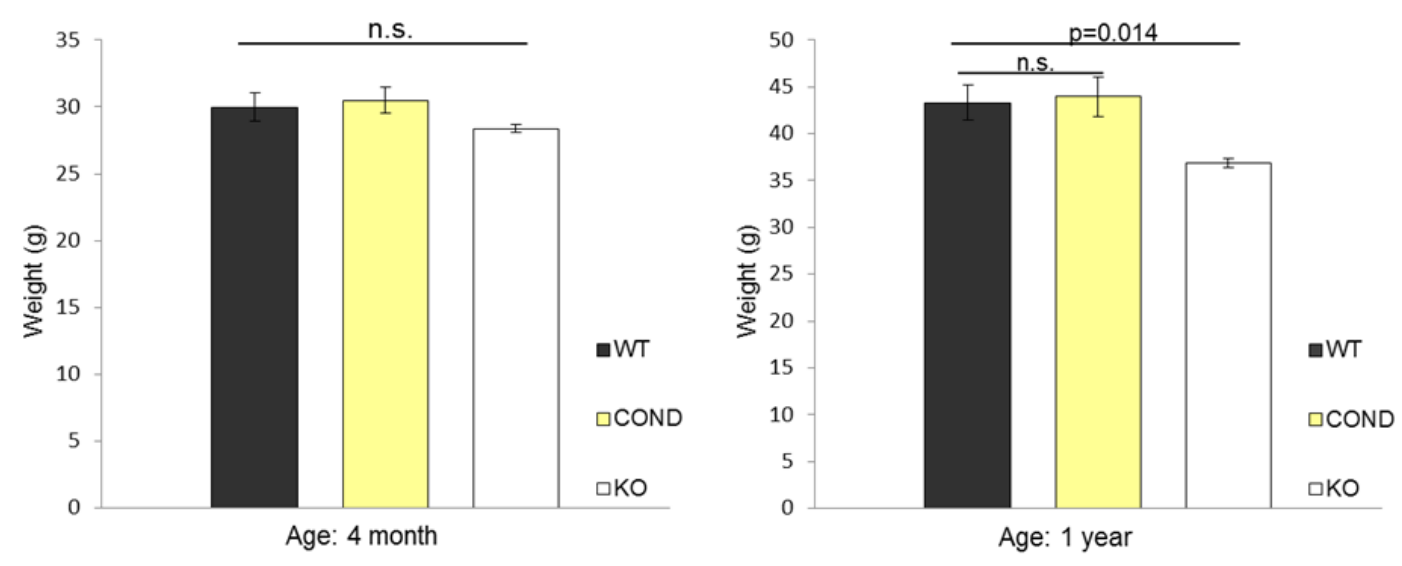

B

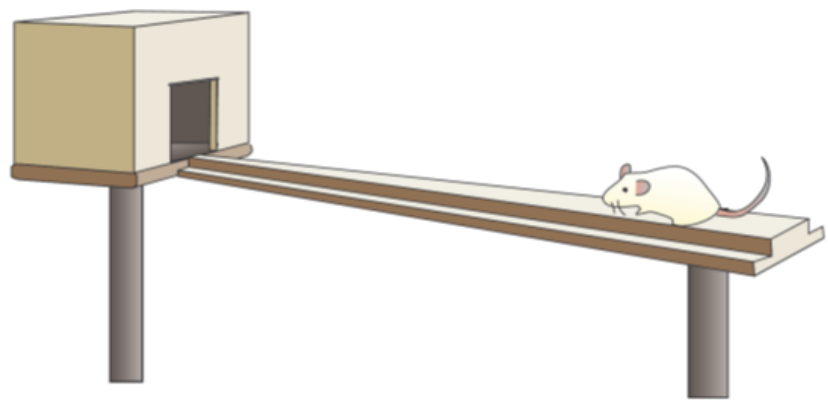

C
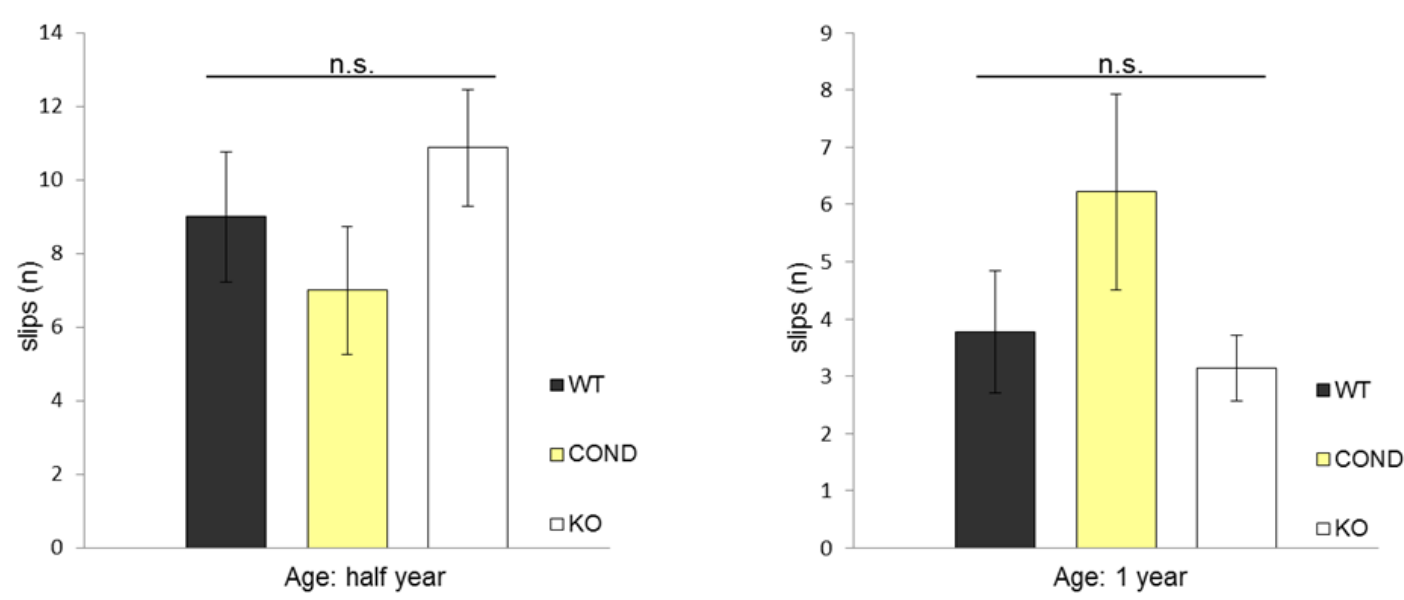

Fig. 11. Weight and motor capabilities of SEPT8-mutant mice. A Animals were weighed at the ages of four months and one year (error bar: SEM). Young adult mice showed no difference between the genotypes. At one year of age, constitutive mutants $(\mathrm{KO})$ were about $17 \%$ lighter than controls (WT) and conditional mutants (COND). B The elevated beam test was used to analyze motor capabilities (illustration taken from Brooks and Dunnett, 2009). C In this test, no differences were found between the analyzed genotypes at any age ( $n=6$, error bar: SEM). 


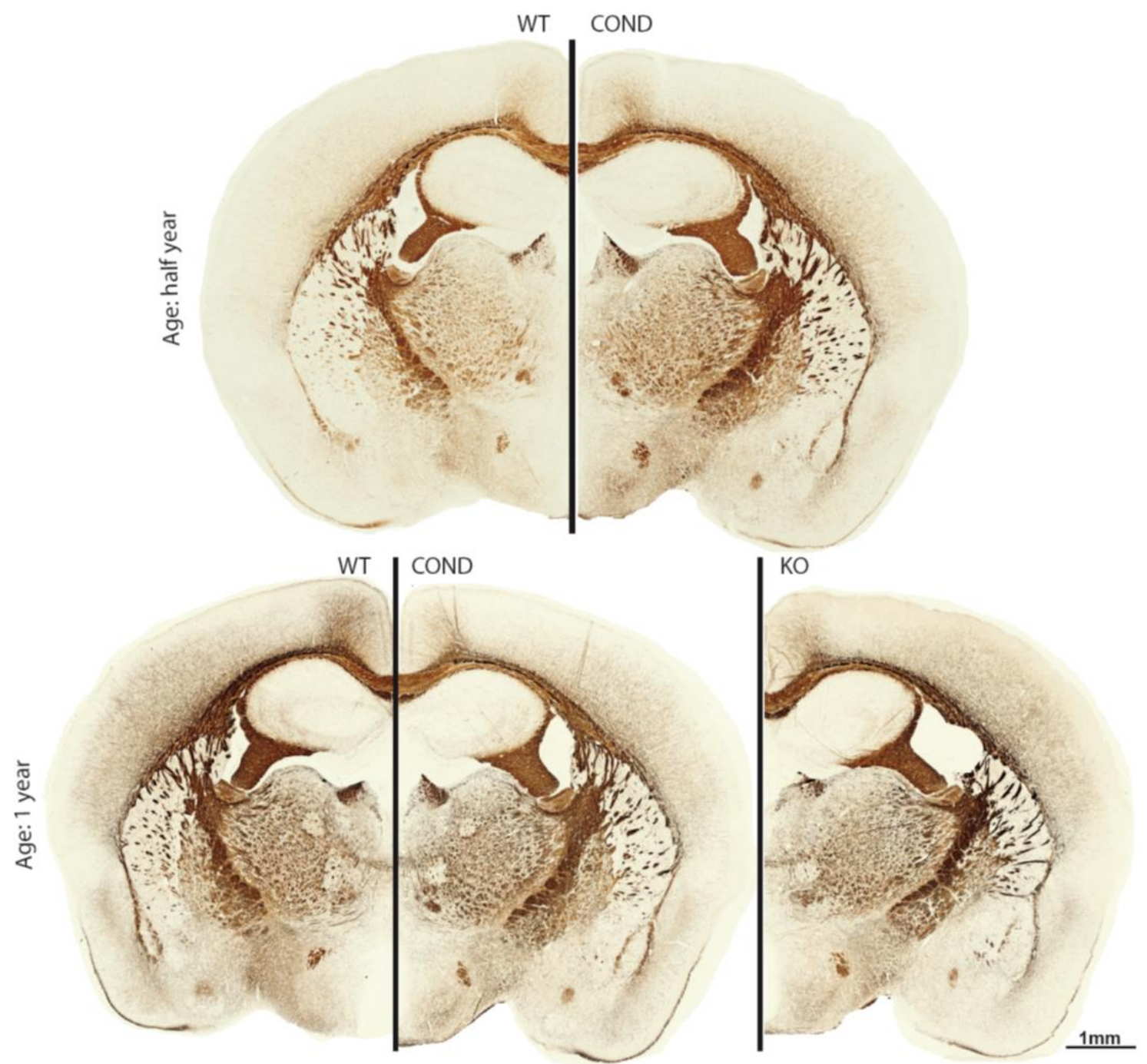

Fig. 12. Brain structure and general myelination of SEPT8-mutant mice. Gallyas silver impregnation was used to analyze brain structure (Gallyas, 1979). Myelin was impregnated in brown. Control and SEPT8-mutant mice were impregnated at half a year or one year of age. The brains were alike in size, morphology and overall amount of myelin. 


\subsubsection{Pathological abnormalities of septin-deficient CNS myelin}

The deletion of SEPT8 expression led to mice that lacked septins from myelin. As myelin abnormalities might not lead to obvious changes in mouse behavior, the structure of myelin was analyzed in more detail. The optic nerves of P75 and half-year old mice were studied. By light microscopy, semi-thin sections of P75 optic nerves from SEPT8 mutant mice and controls were compared (Fig. 13A). Comparing WT and KO, myelin pathology was visible in the optic nerve of KO (Fig. 13A, red arrow head). By electron microscopy, this pathology was identified as myelin outfoldings and redundant myelin. The numbers of myelin outfoldings and redundant myelin loops were quantified. Conditional and constitutive mutants were similar at each time point tested. Both mutants displayed significantly more myelin abnormalities compared to WT. At P75, myelin outfoldings and redundant myelin were four times more abundant in COND and KO than in WT. These myelin abnormalities were progressive with age (Fig. 13B). Also in WT the number of myelin outfoldings increased with age, whereas redundant myelin did not.

Nevertheless, many axonal segments displayed normal myelin. Myelin thickness was analyzed at these segments by measuring g-ratios (Fig. 14A). Apparently, myelin thickness was not changed, as revealed by the comparison between WT and COND. Hypermyelination was thus present exclusively as myelin outfoldings and redundant myelin. These structures accounted for 3 times more area of the optic nerve at P75. More area was occupied by myelin abnormalities at higher age (Fig. 14B). The loss of septins in adaxonal myelin thus led to myelin outfoldings and redundant myelin without a general increase of myelin thickness. 
A

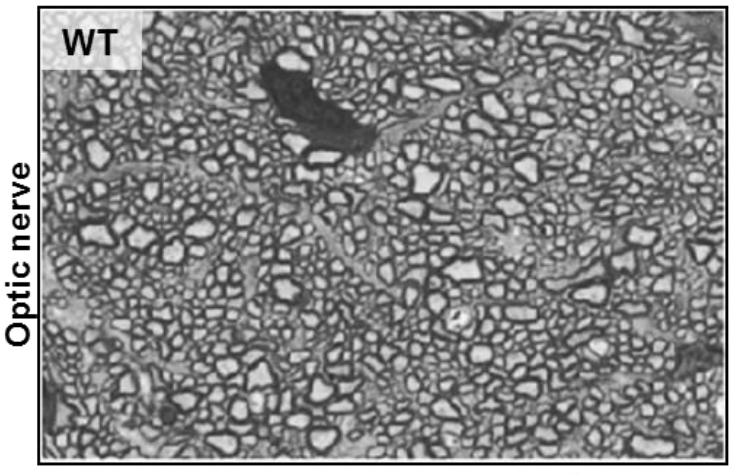

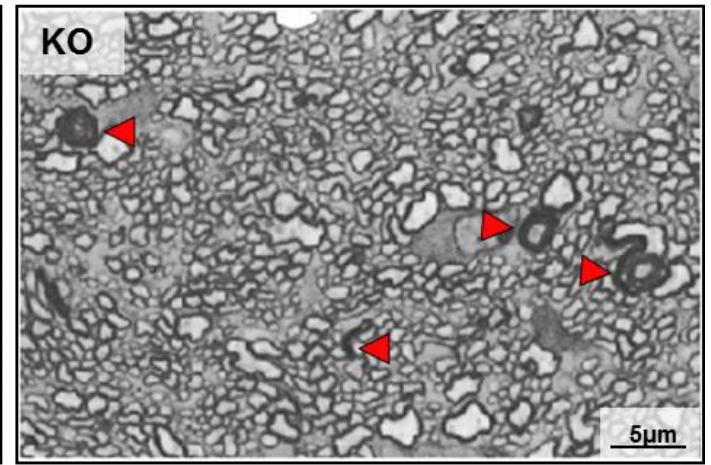

B
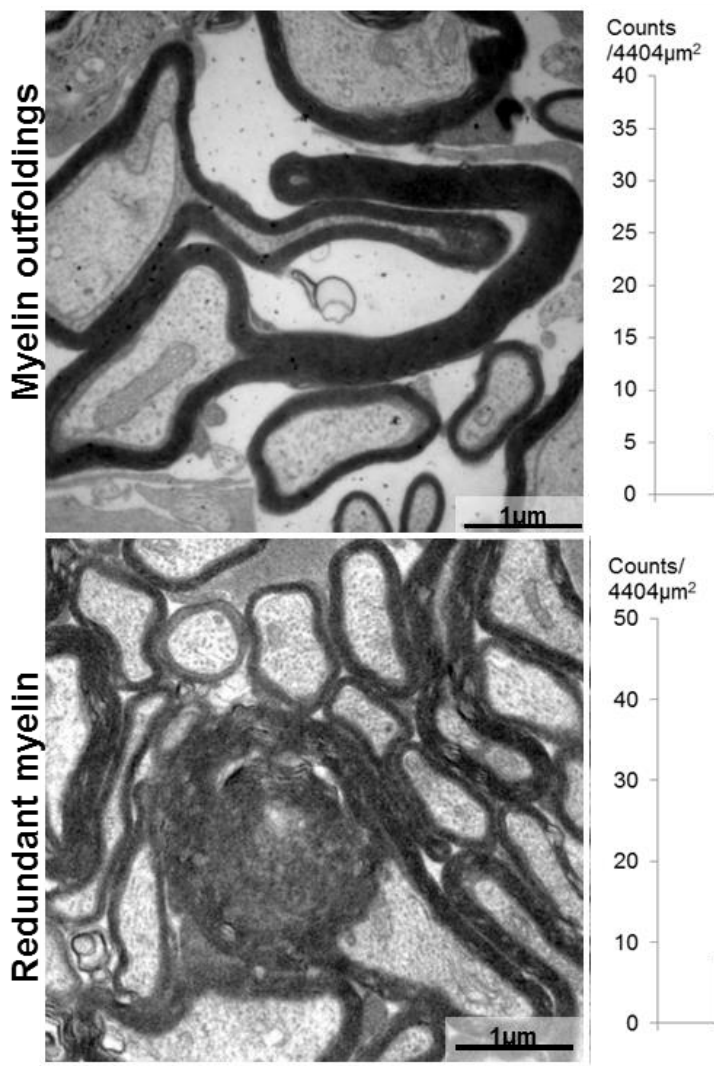

$14404 \mu \mathrm{m}^{2}$
40

$\left.\begin{array}{l}40 \\ 35 \\ 30\end{array}\right]$

25
20

20
15

$10-$
5

0

\section{Counts/ $4404 \mu \mathrm{m}^{2}$} 50

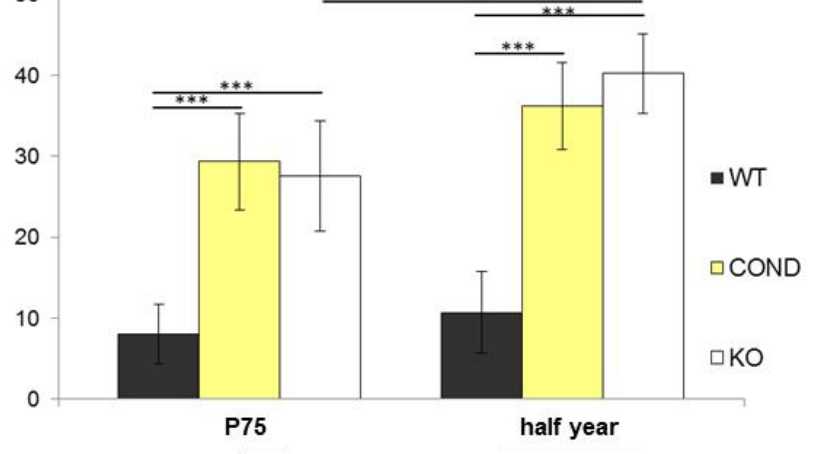

Fig. 13. Myelin abnormalities when SEPT8 is lacking. A Semi-thin sections of optic nerves were prepared at P75. While control (WT) axons appeared normally myelinated, intensely labeled myelin structures (red arrowheads) were apparent in SEPT8 deficient mice (KO). B Optic nerves analyzed by EM revealed myelin outfoldings and redundant myelin. These structures were quantified $(n=6$ per genotype, error bars: SD). The numbers of myelin outfoldings and redundant myelin loops were strongly increased in KO and COND compared to WT. KO and COND were equally affected. Comparing the ages of P75 and half a year, the numbers of myelin outfoldings and redundant myelin profiles were progressive in the mutants $\left({ }^{*} p<0.05,{ }^{* *} p<0.01,{ }^{* * *} p<0.001\right)$. 
A

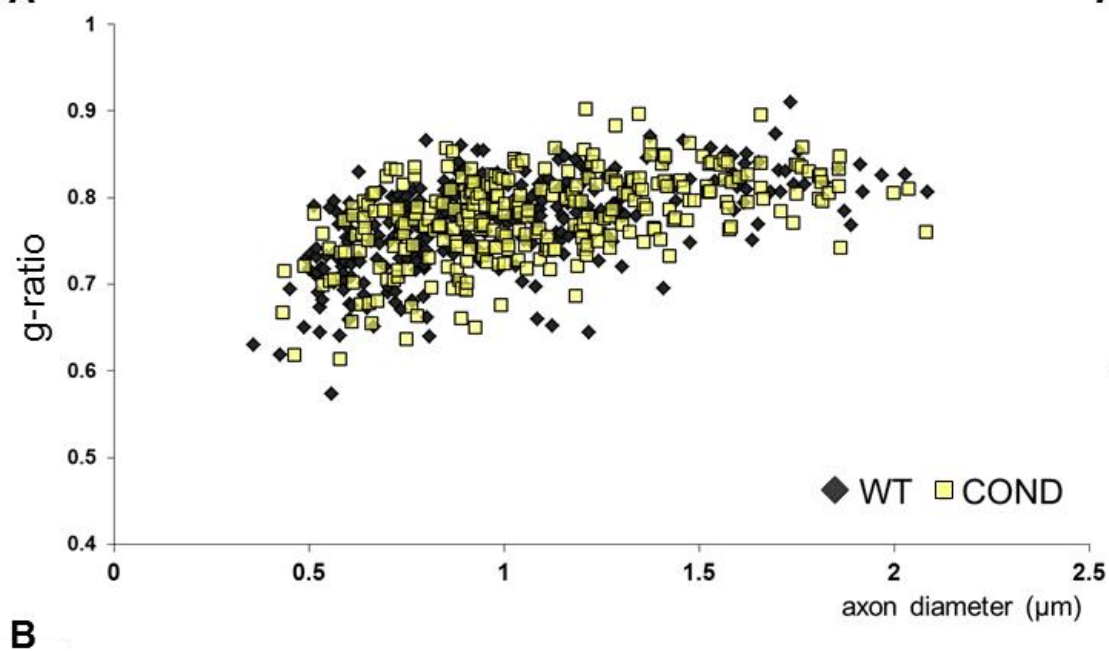

B
A'

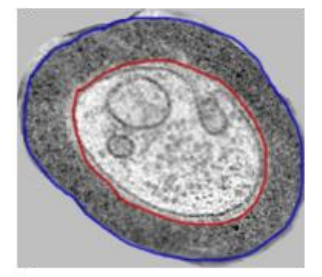

g-ratio $=\frac{\text { axon diameter }}{\text { myelin diameter }}$

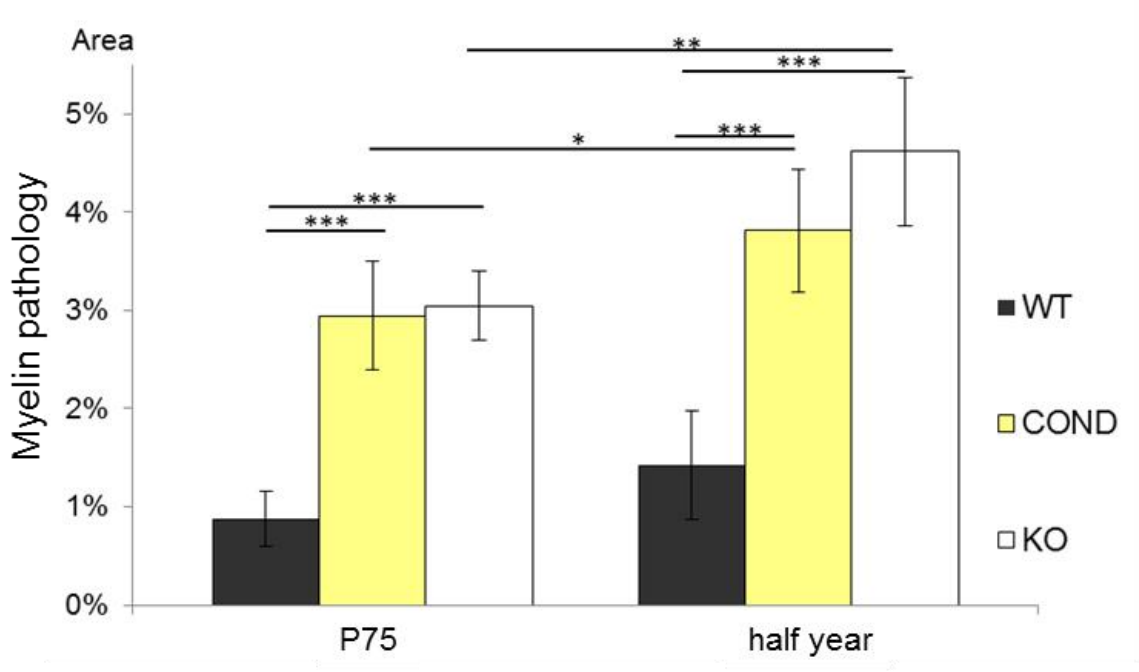

Fig. 14. Myelin thickness and pathology in the optic nerve of SEPT8-mutant mice. A The myelin thickness of healthy-appearing axonal segments was analyzed by measuring the g-ratio. The myelin thickness was unchanged. A' An illustration how the g-ratio was determined. B In contrast, hypermyelinated profiles such as outfoldings and redundant myelin occupied three times more area in COND and KO compared to WT mice at the age of P75, and four times more at half a year. The KO mutant displayed equal changes as COND ( $n=6$ per genotype, error bars: SD, * $\left.p<0.05,{ }^{* *} p<0.01,{ }^{* * *} p<0.001\right)$. 


\subsubsection{Secondary neuropathological effects in SEPT8 deficient mice}

Mice that lack SEPT8 from oligodendrocytes developed myelin abnormalities. Here, the question was raised if outfoldings and redundant myelin affect the health of axons and the surrounding brain tissue. Therefore, mice at the age of half a year or one year were perfused and subjected to immunohistochemistry using neuropathological markers. Amyloid beta precursor protein (APP) is expressed by neurons and transported along axons (Zheng and Koo, 2006). In pathological situations, APP accumulates within axons and is a sign of axonal degeneration (Coleman, 2005, Saxena and Caroni, 2007). The fimbria, a white matter area of the brain, was studied to identify APP accumulations (Fig. $15 \mathrm{~A})$. At the age of half a year no difference regarding APP accumulations was detected comparing WT and COND mice (Fig. 15B). At the age of one year, accumulations of APP were apparent in SEPT8 deficient mice (Fig. 15A and B). Hence, only upon aging SEPT8deficient mice developed moderate axonal pathology. Importantly, Cnp $1^{\text {cre/wt }}$ mice were used as a control group. In COND and Cnp $1^{\text {cre/wt }}$, the abundance of CNP was reduced in myelin. Both groups equally showed signs of axonal pathology. Therefore, not the loss of SEPT8 but the reduced abundance of CNP in myelin affected axonal health. Axonal pathology was also seen in the constitutive SEPT8 mutants (KO). Since SEPT8 is also expressed by neurons, deficiency of neuronal SEPT8 could cause APP accumulations. Taken together, conditional and constitutive SEPT8 deficient mice did indeed display moderate axonal pathology, but septin loss from myelin and subsequent myelin abnormalities are not necessarily the cause.

Microglia react to pathological changes in their environment and are able to phagocytose myelin debris (Cuzner et al., 1988, Mosley and Cuzner, 1996). In a pathological situation, microglia are activated, change into amoeboid cells and express the surface antigen MAC-3 (Ho and Springer, 1983, Giulian and Baker, 1986). MAC-3 was detected by immunohistochemistry and quantified in the fimbria (Fig. 16A). At the age of half a year, no differences between WT and COND were identified (Fig. 16B). MAC-3 positive microglia were detected only in COND at the age of one year (Fig. 16A and B). Hence, the loss of SEPT8 induced microglial activation only together with the reduced abundance of CNP in myelin and upon aging. Analysis of secondary neuropathology was performed with the technical support by the bachelor student Tadzio Wagner. 
A

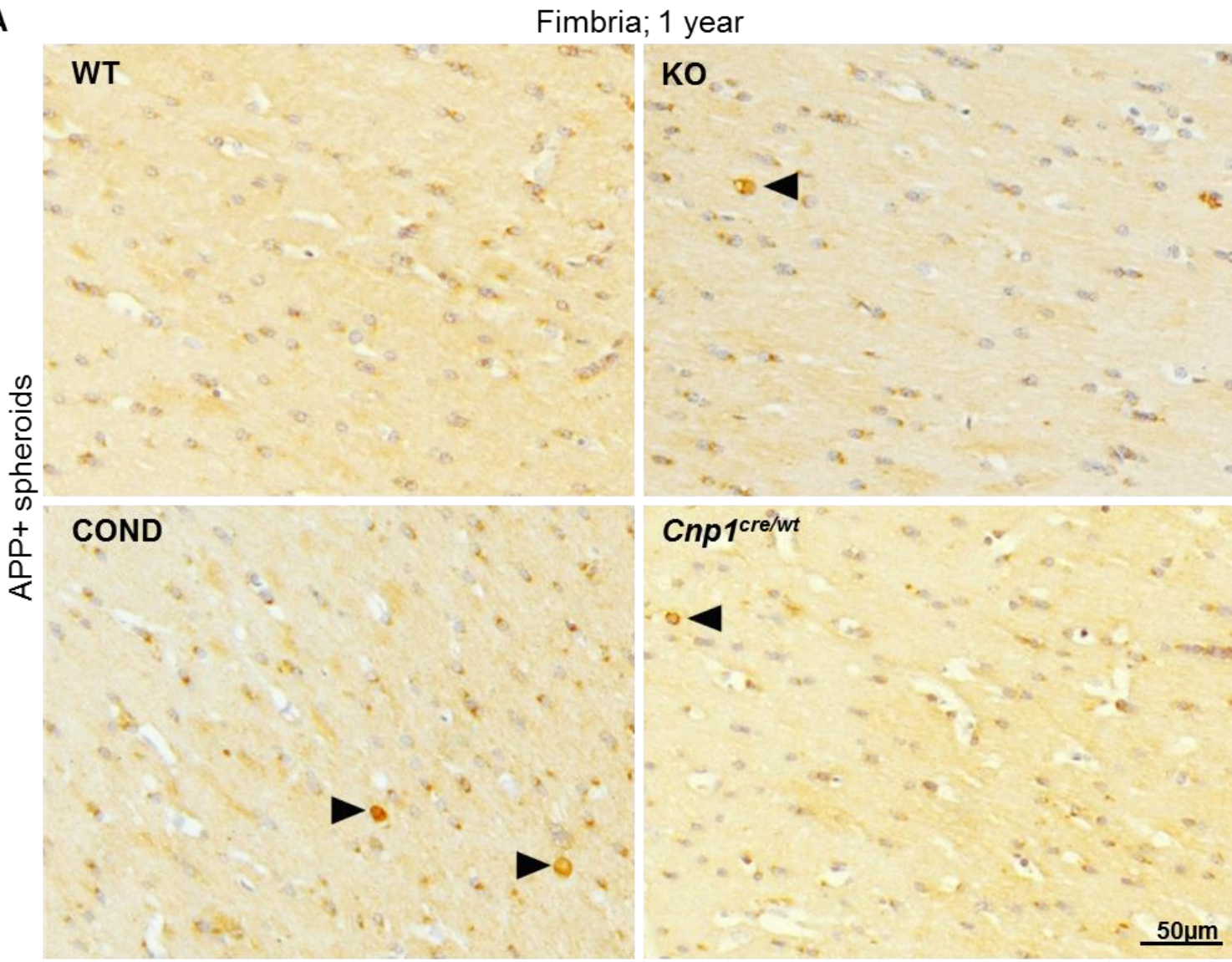

B

Age: half year

Age: 1 year
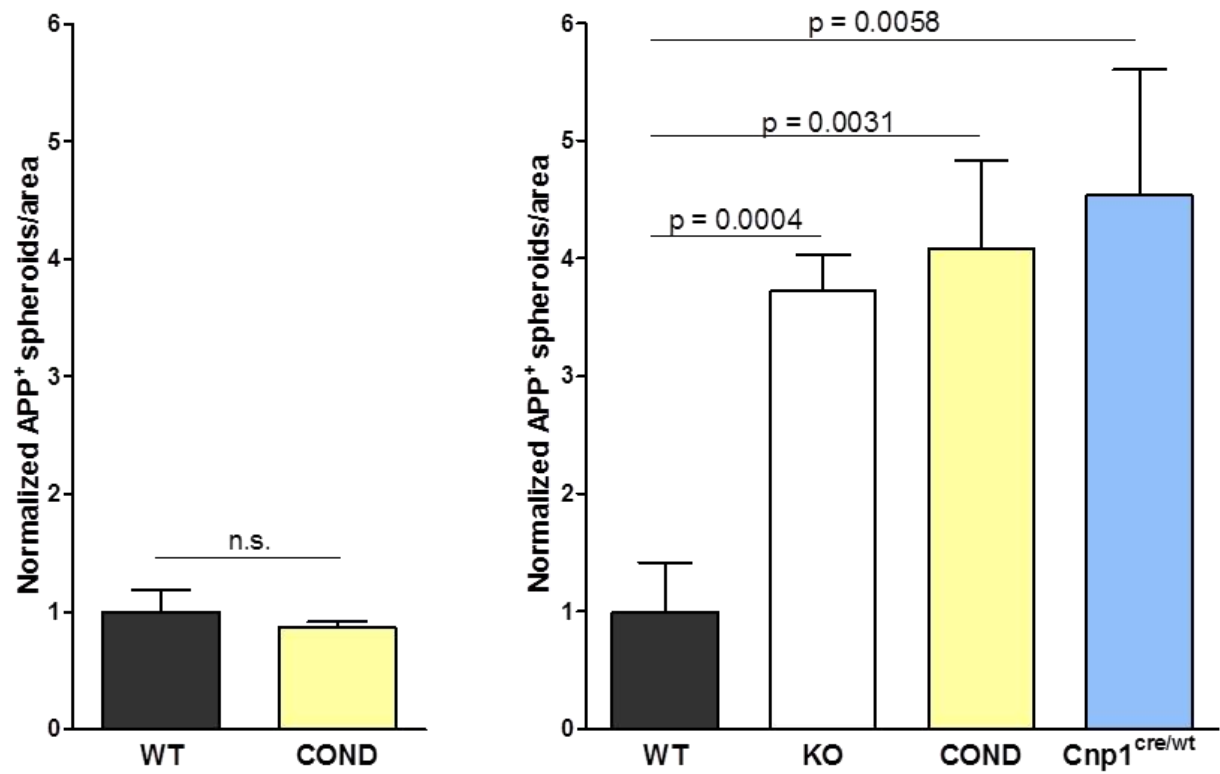

Fig. 15. Axonal pathology in SEPT8-deficient mice. A Amyloid beta precursor protein (APP) was labeled in brains of 1 year old mice. Accumulations of APP (arrowheads) were quantified in the white matter (fimbria) of mutant brains. B At half a year of age, no difference regarding the number of $\mathrm{APP}^{+}$spheroids between WT and COND was found. At one year all analyzed mutants (KO, COND and $C n p 1^{\text {cre/wt }}$ ) developed moderate axonal pathology (error bars: SEM). 
A

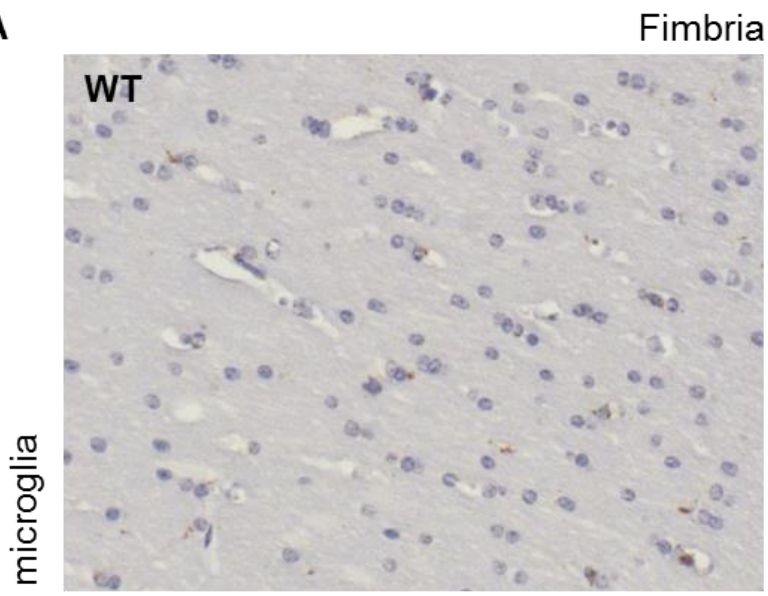

Fimbria; 1 year
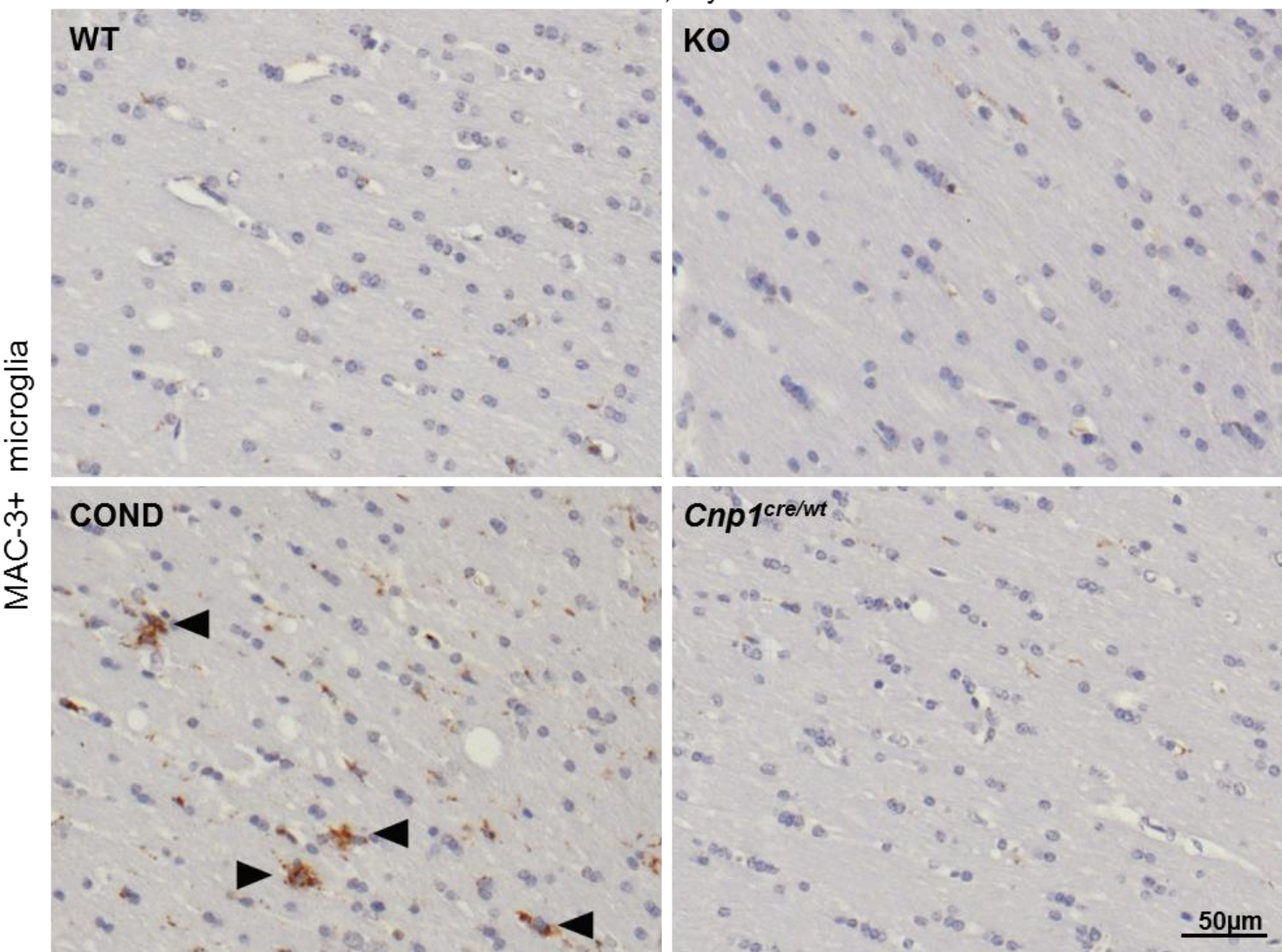

B

Age: half year

Age: 1 year
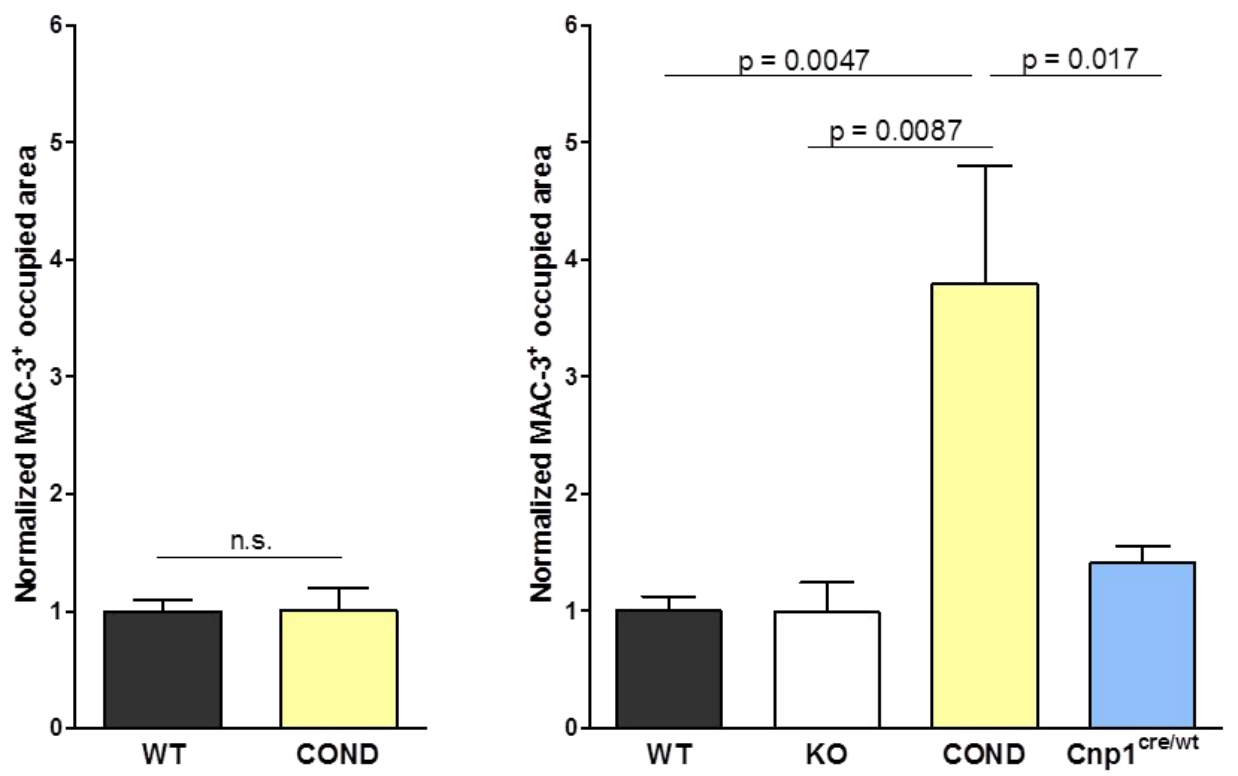

Fig. 16. Inflammation in SEPT8-deficient mice. A MAC-3, a marker of activated microglia, was labeled in brains comparing control (WT) and mutants. The fimbria was analyzed quantitatively as a model of white matter. Considerable numbers of activated microglia were found in COND mice (arrow heads). B Activated microglia were quantified at half a year and one year of age. Only COND mice at one year of age showed a significant elevation of MAC-3 positive microglia (error bars: SEM). 
It was apparent that only with an additional trigger such as reduction of the abundance of CNP, myelin changes in mice lacking SEPT8 led to microglial activation. On the other hand, it was possible that the deletion of SEPT8 in all cells of the brain might impair microglial activation. To approach this, the model of experimental autoimmune encephalomyelitis (EAE) was used to further study the role of SEPT8 in microglial activation. WT and KO mice were injected with MOG peptide 35-55 at the age of 14 weeks and observed daily. Both groups developed symptoms of EAE, as walking deficits and hindlimb paralysis. At day 14 after injection, animals were sacrificed and immunolabeled for MAC-3, the marker of activated microglia (Fig. 17A). The lumbar part of the spinal cord was analyzed for activated microglia. In both WT and KO mice, activated microglia were apparent, suggesting that microglial activation is not impaired in SEPT8 constitutive mutants.

More importantly, it was of interest if morphological changes of septin-deficient myelin led to a different course of EAE. EAE induction in mice led to a high variability of the disease course and no significant differences between the genotypes were found under the used experimental conditions. Comparing microglial activation between WT and KO at day 14 post injection, MAC-3 labeling was increased in $\mathrm{KO}$, but not significantly when comparing 6 animals per genotype (Fig. 17B).

Taken together, pathological analyses of SEPT8 deficient mice showed that myelin outfoldings do not induce obvious axonal pathology or inflammation per se. Only when further stressors such as the reduction of CNP or the induction of EAE were applied, indeed myelin outfoldings affected the disease progression. 
A

Ventral spinal cord after induction of EAE
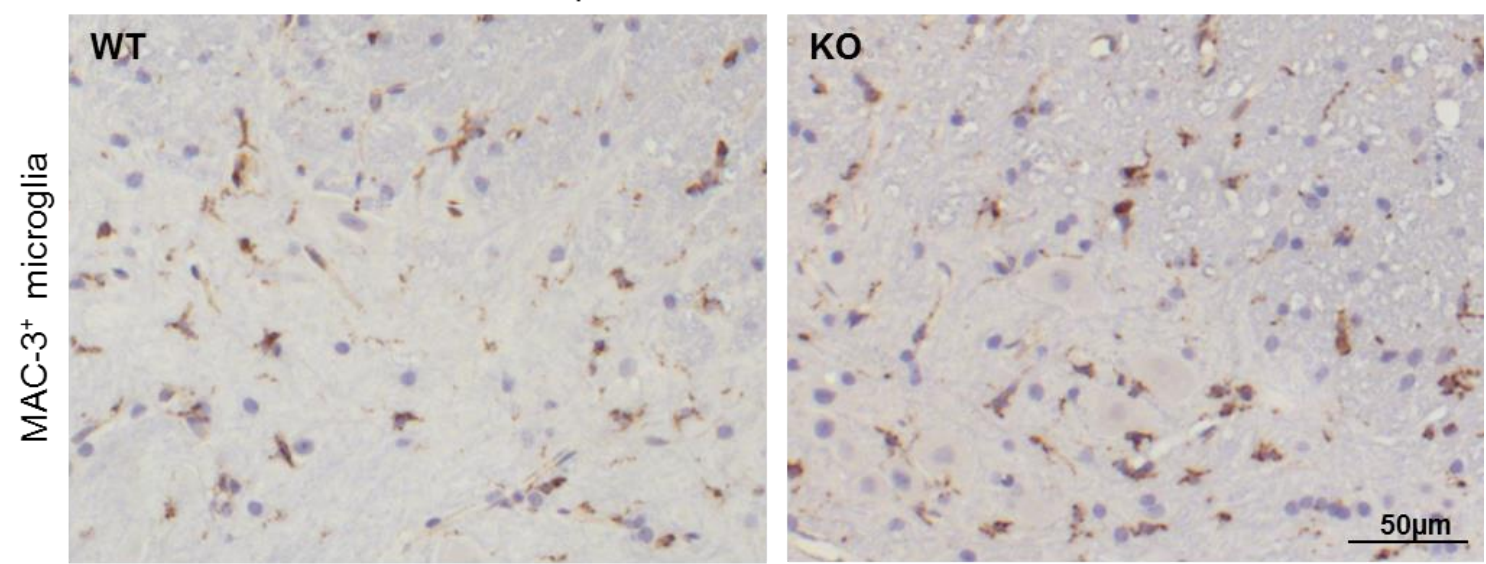

B

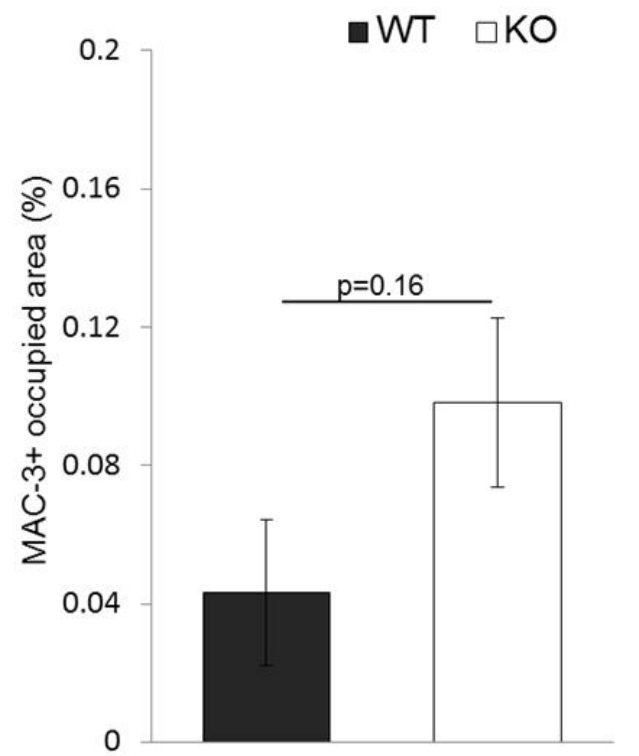

C

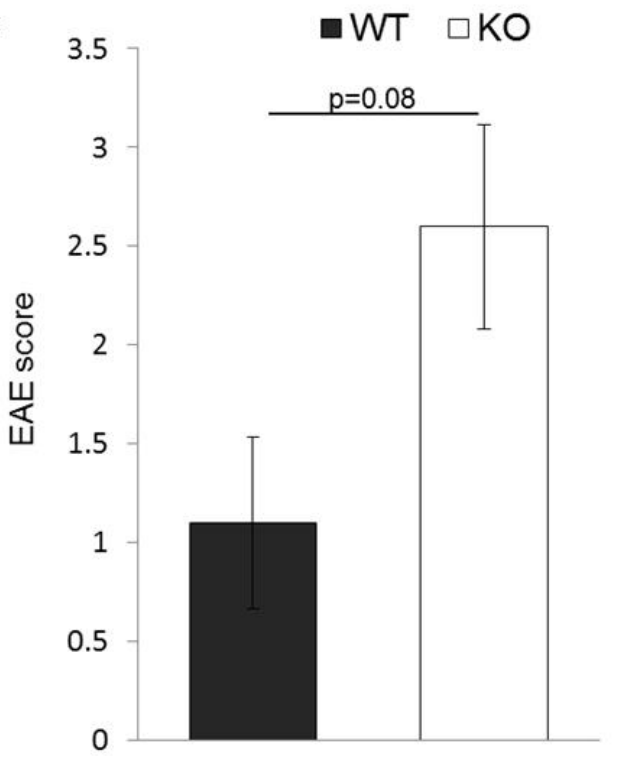

Fig. 17. Inflammation after EAE induction in SEPT8-mutants. A MAC-3, the marker for activated microglia, was labeled in the lumbar spinal cord 14 days after EAE induction. Constitutive SEPT8 mutants displayed robust microglia activation. B Comparing WT and KO, MAC-3 positive area appeared moderately increased in mutants, but this did not reach significance. $\mathbf{C}$ The EAE score was not significantly increased in KO compared to WT mice. (error bars: SEM). 


\subsection{Septins in peripheral myelin}

\subsubsection{Localization of septins in Schwann cells}

Similar to CNS myelin (see above) septins are abundant proteins in peripheral myelin (Buser et al., 2009, Patzig et al., 2011). Schwann cells, the myelin forming cells of the peripheral nervous system, were subjected to immunohistochemistry to determine the localization of septins. Axons of sciatic nerves were separated and teased fibers were immuno- labeled for SEPT7 and SEPT9 (Fig. 18). Either septin was exclusively detected in the abaxonal cytoplasmic channels of the Schwann cells, termed bands of Cajal. Hence, septin localization in peripheral myelin differed principally from that of CNS myelin.
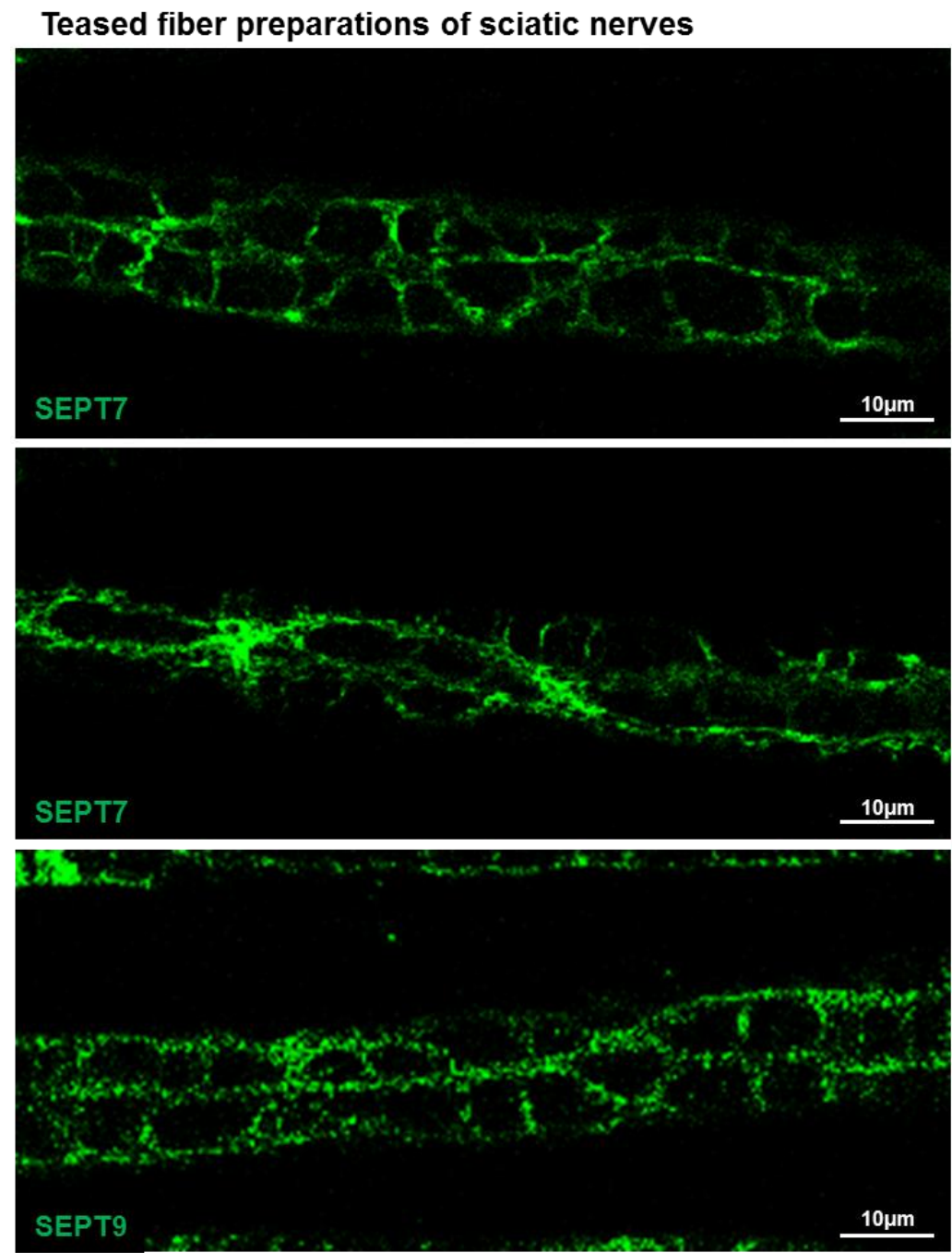

Fig. 18. Abaxonal localization of septins in peripheral myelin. SEPT7 and SEPT9 were labeled in preparations of single axons of the sciatic nerve (teased fibers). By confocal imaging, septins were detected in the abaxonal cytoplasmic channels of Schwann cells, termed bands of Cajal. 


\subsubsection{SEPT8 deficient Schwann cells}

CNP is a myelin protein also expressed by Schwann cells in the peripheral nerves (Sprinkle, 1989). Therefore the Cnp1-promotor driven expression of Cre recombinase did also lead to the deletion of SEPT8-expression in Schwann cells. Since SEPT8 loss in oligodendrocytes led to myelin abnormalities, myelin of the sciatic nerves was also analyzed. By light microscopy, semi-thin sections of sciatic nerves from half year old animals were studied (Fig. 19A). Myelin appeared normal in COND compared to WT. No changes such as outfoldings or redundant myelin were detected.

By immunoblot, the abundance of septins in sciatic nerve lysates was studied (Fig. 19B). The abundance of SEPT8 was strongly decreased in the COND sciatic nerves, suggesting that most SEPT8, which was detectable in the sciatic nerves, was indeed expressed by Schwann cells. In KO nerves, all SEPT8 signal was lost. SEPT2, SEPT7 and SEPT9 were detected in sciatic nerve lysates and none were diminished in COND or KO lysates. The abundance of SEPT2 and SEPT7 was quantified, and no significant change was identified (Fig. 19B). SEPT4 and SEPT6 were not detectable in sciatic nerves. SEPT11 was also detectable in the sciatic nerve lysates. In COND and KO nerves, the abundance of SEPT11 was found to be increased significantly suggesting the possibility of functional compensation (Fig. 19B). Immunoblot experiments were performed with technical support by the bachelor student Andrea Franz. 


\section{A}

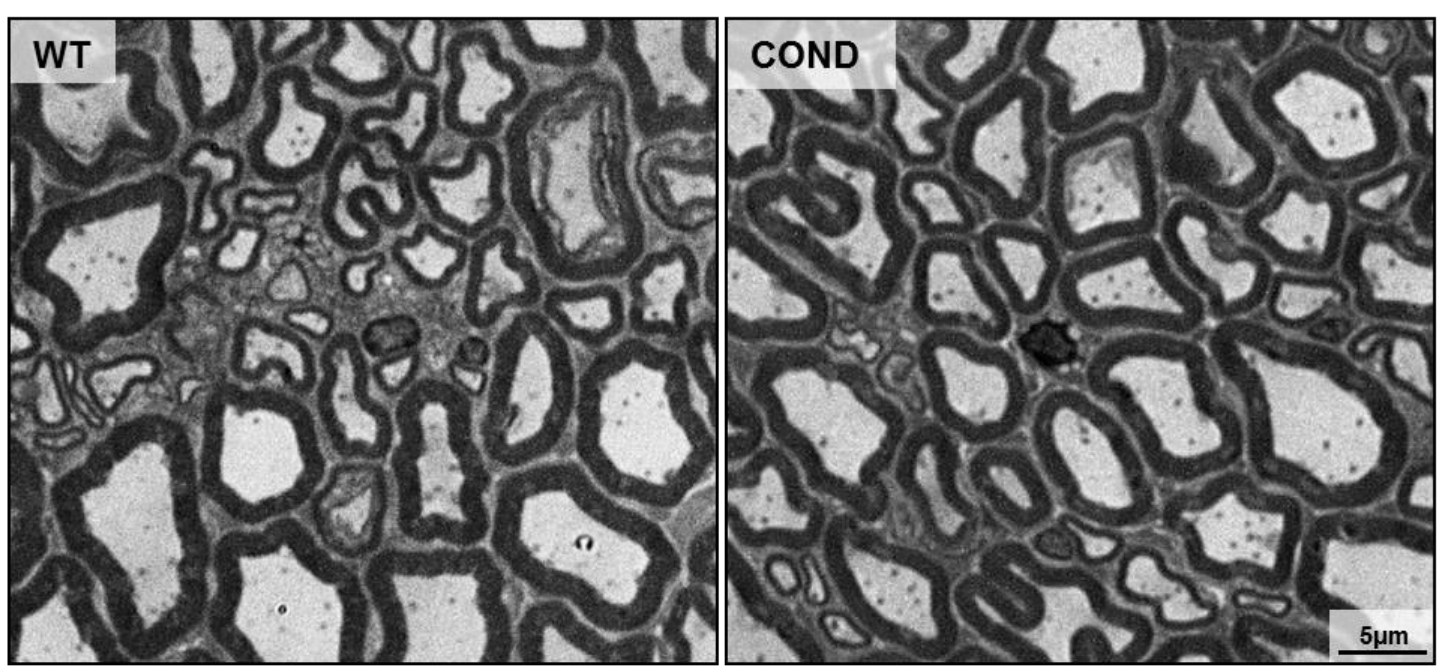

B

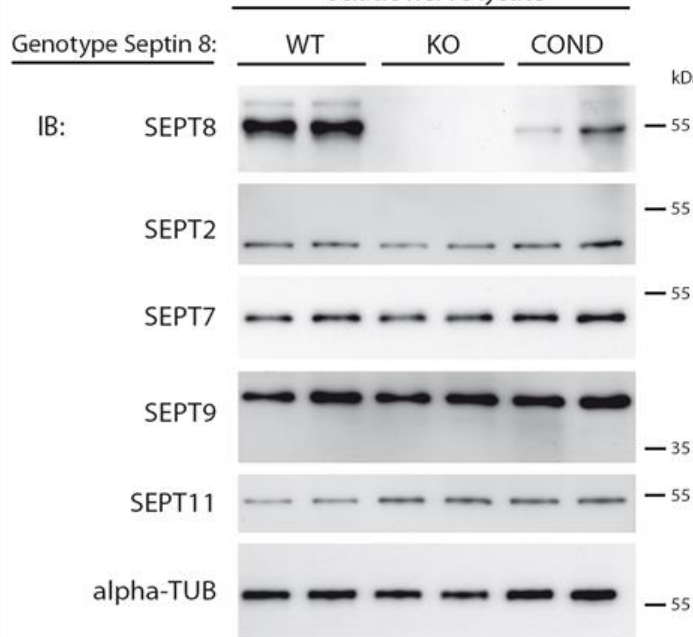

sciatic nerve lysate
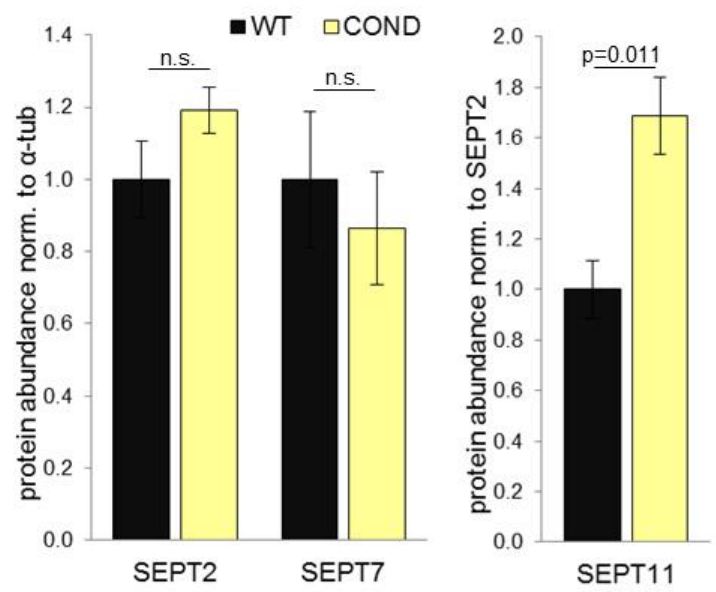

Fig. 19. Analysis of the PNS in SEPT8-deficient mice. A By light microscopy, semi-thin sections of sciatic nerves were analyzed in control (WT) and conditional SEPT8 mutants (COND) at half a year of age. No apparent difference was detected in myelin structure or thickness. B The abundance of septins was analyzed by immunoblot. The abundance of SEPT8 was strongly reduced in COND, and SEPT8 was undetectable in KO nerves. Other septins such as SEPT2, SEPT7, and SEPT9, were unchanged in abundance. The abundance of SEPT11 was significantly increased in SEPT8-mutant sciatic nerves ( $n=4$, error bars: SEM). 


\section{Discussion}

Myelin is a complex specialization of the plasma membrane of oligodendrocytes and Schwann cells important for fast nerve conduction. Furthermore, recent studies have shown that axonal integrity depends on functional myelinating glial cells (Nave, 2010). To uncover mechanisms important for the structural integrity of myelin, we and others have systematical analyzed its protein content. The work presented here characterizes the septin family of cytoskeletal proteins in myelin and its function in the maintenance of myelin integrity.

\subsection{Septins are abundant constituents of mature CNS myelin}

Previously, several studies have shown various septins as abundant constituents of CNS myelin in mice and humans using 2D-IEF/SDS-PAGE (Werner et al., 2007, Ishii et al., 2009). We have now analyzed the protein content of myelin by gel-free LC-MS ${ }^{E}$. This method allows protein identification without previous gel separation and quantitative comparison of individual protein abundances (Jahn et al., 2013). Our results confirm that indeed SEPT2, SEPT4 and SEPT8 are abundant in CNS myelin of mice in agreement with immunoblot experiments (Fig. 4B) and prior studies (Werner et al., 2007, Buser et al., 2009, Fewou et al., 2010). SEPT7 was newly detected as the second most abundant septin in myelin (Fig. 4C). The observed higher abundance of SEPT7 in brain lysates compared to myelin (Fig. 4B) is likely due to the proposed ubiquitous expression of SEPT7 (Kinoshita, 2003, Mostowy and Cossart, 2012). Thus, SEPT7 is a component of myelin, also not enriched.

Based on quantitative gel-free MS and immunoblot, SEPT2, SEPT4, SEPT7 and SEPT8 are constituents of CNS myelin. Septins are known to assemble into oligomers in a 1:1:1 relationship. A 2/6/7-oligomer was previously described (Sheffield et al., 2003, Low and Macara, 2006, Sirajuddin et al., 2007) and it was suggested that homologous septins could replace one another in this oligomer (Kinoshita, 2003, Mostowy and Cossart, 2012). Considering the homology groups within the septin protein family, we suggest that in myelin SEPT8 takes the position of SEPT6 in the oligomer. SEPT2 and the related SEPT4 together are about as abundant as SEPT8 and SEPT7. Hence, we predict myelin septin oligomers to consist of $2 / 8 / 7$ as well as $4 / 8 / 7$ core assemblies (Fig. 20B). 


\subsection{Reduced abundance of myelin septins in mouse mutants affecting myelin-related genes}

The deletion of various myelin-related genes results in secondary axonal pathology. It has been hypothesized that oligodendroglial support of axons is impaired in these mutants (Nave, 2010). However, the underlying mechanism has not been identified. When systematically comparing the protein content of myelin purified from PLP $^{\text {null }}$ and CNP ${ }^{\text {null }}$ mutants, the abundance of myelin septins was considerably decreased (Fig. 4D). We hypothesize that altered septin abundance is part of the observed pathology. In both mutants, various septins are not reduced to a similar level suggesting that the observed changes might be caused by different molecular upstream cascades. Future analysis may show if an additive effect leads to a further diminishment of myelin septins in mice lacking both PLP and CNP contributing to the observed enhanced neurological phenotype (Edgar et al., 2009).

Several functions of septins are conceivable in myelin. Septins have been shown to be involved in vesicle transport and exocytosis (Dent et al., 2002, Gilden and Krummel, 2010, Yang et al., 2010). Speculatively, a reduced abundance of myelin septins might influence the secretion of multivesicular bodies / exosomes toward the axon. If these vesicles contain molecules important for axonal function (Kramer-Albers et al., 2007), their deficiency might lead to axonal pathologies as observed in PLP $^{\text {null }}$ and CNP ${ }^{\text {null }}$ mice. Furthermore, septins influence membrane rigidity and act as diffusion barriers (Hall and Russell, 2012, Spiliotis and Gladfelter, 2012). Hence, septins could influence the integrity of myelin, which might be also relevant for axonal function. To increase the knowledge about the functional relevance of myelin septins, SEPT8 was deleted from oligodendrocytes by gene targeting.

\subsection{SEPT8 is essential for septin filament assembly in CNS myelin}

Secondarily to the deletion of SEPT8 in myelin, SEPT2, SEPT4, SEPT7, and SEPT9 were diminished (Fig. 10A). It was previously described in E.coli that septins were only stable upon the co-expression of at least two septin monomers of different homology groups (Sheffield et al., 2003). Additionally, in mammalian cell lines, it was shown that the presence of at least one member of the SEPT6-homology group (compare Fig. 20) is essential for oligomer formation (Sellin et al., 2011). Therefore, our data indicate that SEPT8 is essential for the formation of septin oligomers and/or filaments in myelin. Furthermore, it was shown that the effect of SEPT8-deficiency on other myelin septins is post-translational (Fig. 10C). This supports the concept that indeed these septins 
assemble into filaments in the adaxonal myelin compartment. Thereby, the loss of SEPT8 likely leads to protein instability and degradation of the interaction partners.

For SEPT9, only the $39 \mathrm{kDa}$ isoform was abundant in CNS myelin, and diminished in SEPT8- deficient myelin (Fig. 10A). It was recently suggested that this smallest splice isoform of SEPT9 might be the endpoint a filament (Kim et al., 2011). This is feasible since SEPT9 is of very low abundance when compared to other myelin septins. Furthermore, the loss of SEPT9 in SEPT8-deficient myelin confirms SEPT9 as an interaction partner of SEPT8, also considering double immunohistochemistry (Fig. 7B).

The close homologs SEPT2 and SEPT4 are about equally abundant in CNS myelin (Fig. 4C). To further understand filament assembly, the abundance of SEPT2 and SEPT8 was tested in SEPT4-deficient myelin (Fig. 10D). Whereas the abundance of SEPT8 was unchanged, the abundance of SEPT2 was about doubled. Redundancy within septin homology groups has been described for example in neurons, in which the abundance of SEPT2 was increased when SEPT5 was deleted (Peng et al., 2002). Interestingly, the deletion of SEPT4 led to septin dysfunction in sperm cells, in which the other homology group members SEPT2 or SEPT5 are not expressed (Kwitny et al., 2010). Hence, we assume that in myelin SEPT2 and SEPT4 may occupy the same position in the septin oligomer and may indeed be redundant (Fig. 20B).

SEPT11 is a close homolog of SEPT8 (Fig. 20A). It has been predicted that homologs within the SEPT6 group may also occupy each other's position in the septin filament, provided they are expressed in the same cell (Kinoshita, 2003, Buser et al., 2009). In wild type and SEPT8-deficient myelin, the abundance of SEPT11 was not altered (Fig. 10A). Hence, there is no indication that SEPT11 would compensate for the loss of SEPT8 in CNS myelin. The biology of SEPT11 in myelinating glia and in other cells presently remains largely speculative. 
A

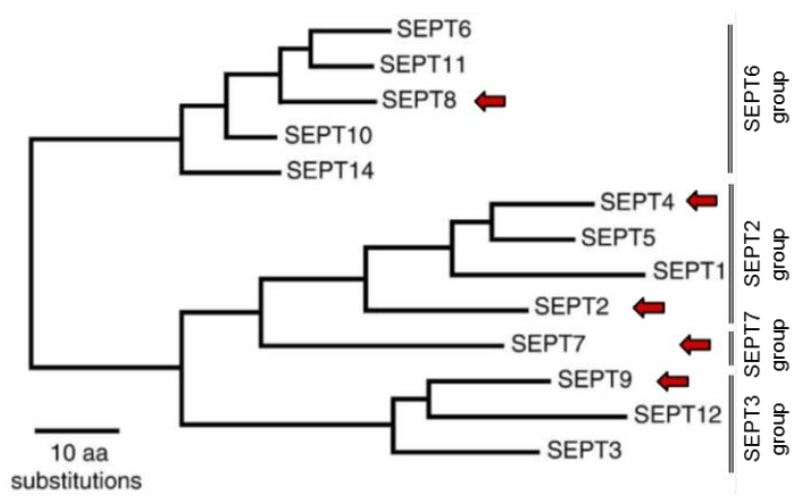

B

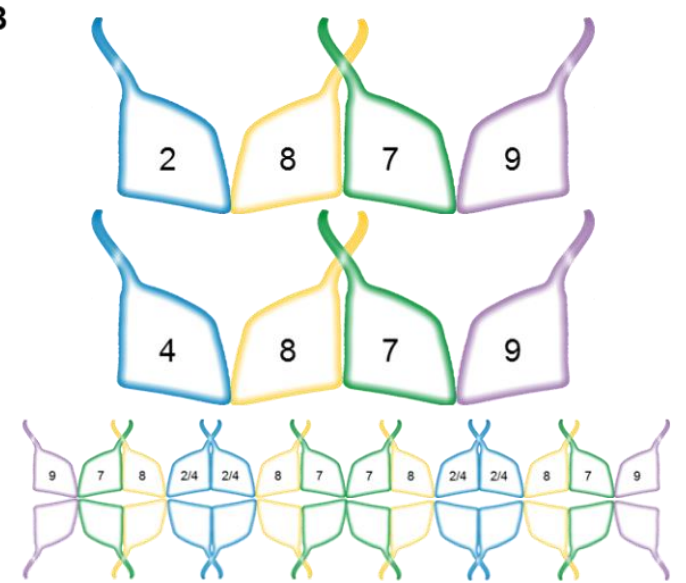

Fig. 20. Myelin septin filament assembly. A The biochemical and histological analyses of wild type and SEPT8-deficient myelin presented in this study indicate that SEPT2, SEPT4, SEPT7, SEPT8, and SEPT9 are abundant constituents of the internodal adaxonal myelin compartment. Thereby, at least one member of each of the four homology groups of septins has been identified (red arrows; phylogenetic tree taken from Buser et al., 2009). B Based on these findings and considering published literature on the assembly of septin filaments in various in vitro systems (Kinoshita, 2003, Nagata et al., 2004, Sirajuddin et al., 2007, Kim et al., 2011, Sellin et al., 2011, Hall and Russell, 2012), we propose the depicted model of the monomer composition of the septin filament in myelin in vivo.

\subsection{The presence of anillin in CNS myelin depends on septins}

Apart from the altered abundance of myelin septins, only one protein was diminished to below 50\% in SEPT8-deficient myelin, namely anillin (Fig. 10B). Association of septins and anillin has been shown in several studies. For instance, anillin and septins co-localize at the cleavage furrow of yeast cells, in which they are essential for cell divisions (Oegema et al., 2000, Maddox et al., 2007). Furthermore, anillin was shown to enhance septin filament formation in vitro in dependence of the membrane lipid phosphatidylinositol 4,5-bisphosphate (PI(4,5)P2) (Kinoshita et al., 2002, Liu et al., 2012). Remarkably, our observations indicate an apparently reverse effect; the loss of septins led to a strongly decreased abundance of anillin in myelin. Since anillin is described as a positive regulator of the septin filament multimerization, and based on the unaltered mRNA abundance (Fig. $10 \mathrm{C})$, it is unlikely that the reduction is due to mechanisms involving transcriptional regulation. We thus suggest that anillin interacts with the septin filament in adaxonal myelin and is thereby stabilized. The proposed molecular interaction will be directly tested once a specific antibody is available. 


\subsection{Septins localize to internodal adaxonal myelin}

We have newly identified a unique localization of myelin septins, which is a basis to uncover their function. We showed that septins assemble as filaments in the internodal adaxonal compartment of CNS myelin and thereby marked a novel subdomain (Fig. 6A and B). Proteins mediating glial-axonal interactions in the paranodal, juxtaparanodal, and nodal segments are well established (Poliak and Peles, 2003), but hardly any knowledge is available regarding the intercellular interactions in the internodal segment. However, as a large proportion of the axon is ensheathed by myelin a stabilizing cytoskeletal septin filaments might indeed affect myelinated axons.

Not much is known about the molecular and structural organization of the internodal adaxonal membrane, which is relevant to be considered as septin cytoskeleton might also serve as a scaffold for important mediators of glial-axonal interaction and axonal integrity. This concept was tested by analyzing the abundance and localization affecting myelinassociated glycoprotein (MAG), which is an abundant Ig-CAM localized to adaxonal myelin and the major marker of this membrane (Trapp and Quarles, 1982, Trapp et al., 1989). We could show that septin loss did not affect its abundance or localization. By quantitative MS of SEPT8-deficient myelin, no proteins were altered in abundance that could be candidates to reside in adaxonal myelin. However, alterations of a protein's localization may not necessarily be revealed by the analysis of its abundance. For the proteins Caspr and Kv1.2, which were used to mark the paranodal and juxtaparanodal segments of axons respectively, no alteration in abundance or signal intensity were detected in SEPT8-defient mice by immunohistochemistry. Hence, the described changes of the localization of Caspr in CNP ${ }^{\text {null }}$ mice (Rasband et al., 2005) appear unrelated to the decreased septin abundance. Neurofascin155, a glial protein localizing to the paranodal segment (Zonta et al., 2008), was another candidate to rely on adaxonal septins for its subcellular localization. By immunohistochemistry, co-localization with Caspr was analyzed in SEPT8-defient mice; however no alterations were observed (data not shown).

In summary, we identified the septin filament as a novel cytoskeletal component of internodal adaxonal myelin. We have speculated that myelin septins could potentially influence the localization of other proteins in adaxonal myelin. However, no such proteins were found, suggesting that any pathology observed in SEPT8-mutants at the cellular level is directly caused by the affected septins. 


\subsection{Mice lacking SEPT8 - development and behavior}

Conditional and constitutive SEPT8-mutants were observed from birth up to one and a half years of age. Several septins have been described to be essential in mammalian cytokinesis (Hall and Russell, 2004, Kremer et al., 2007, Fuchtbauer et al., 2011). The viability of constitutive SEPT8-mutants and the unimpaired breeding strongly suggest that SEPT8 is not critical for cell division.

$\mathrm{CNP}^{\text {null }}$ and PLP ${ }^{\text {null }}$ mice show differences in pathology progression. Whereas CNP ${ }^{\text {null }}$ mice develop motor impairments already at an age of half a year, PLP ${ }^{\text {null }}$ show similiar abnormalities at about 16 months of age (Griffiths et al., 1998, Lappe-Siefke et al., 2003). SEPT8-deficient mice did not show comparable motor impairments (Fig. 11C) up to at least 18 months of age. The reduced weight of one year old constitutive SEPT8-mutants is unlikely to be related to oligodendrocyte function, according to control experiments in conditional mutants.

Silver impregnation of myelin was used to evaluate the overall brain structure (Fig. 12). The size of hippocampus, cortex, ventricles and myelinated areas were comparable to controls at different ages. Hence, SEPT8 is not essential for general development and maintenance of the brain.

\subsection{Septin loss impairs the integrity of adaxonal myelin}

The expression of SEPT8 increases to detectable levels rather late in the development of mouse brains (>P15) and in a late stage of oligodendrocyte differentiation (Tsang et al., 2011, de Monasterio-Schrader et al., 2012). Therefore, any effect of SEPT8 on the initiation of myelination was not to be expected. At P75, there were no obvious differences in the number of myelinated axons in the optic nerve (data not shown). Furthermore, myelin thickness was unchanged according to g-ratio (Fig. 14A).

Interestingly, myelin pathology was frequent in mutant optic nerves (Fig. 13A). By EM, these changes were identified as myelin outfoldings and redundant myelin, which increased with age (Fig. 13B). Hence, SEPT8 and interacting myelin septins do not affect myelin thickness but myelin integrity. The localization of the septin filament in adaxonal myelin together with the structure of myelin outfoldings support the hypothesis that the pathology is due to diminished stabilization of the adaxonal myelin compartment. Mouse mutants lacking particular regulatory factors such as PTEN or CDC42 have also been reported to develop myelin outfoldings (Thurnherr et al., 2006, Goebbels et al., 2010). In contrast to these signaling proteins, septins can be considered endpoints of signal cascades, and there is no indication that they would be involved in the regulation of gene 
expression. We hypothesize that the loss of the septin filament from adaxonal myelin locally leads to myelin instability and therefore to the observed structural changes.

Furthermore, it is theoretically possible to relate the structural myelin alterations in both, PTEN- or CDC42-deficient mice to a negative regulation of the septin filament. In PTENmutant mice, Phosphatidylinositol 4,5-bisphosphate (PI(4,5)P2) levels are diminished (Goebbels et al., 2010). Since it was demonstrated that $\mathrm{PI}(4,5) \mathrm{P} 2$ is essential for higher order structures of septins (Tanaka-Takiguchi et al., 2009, Bertin et al., 2010), functional loss of septins in PTEN-deficient myelin is possible. The relevance of $\mathrm{PI}(4,5) \mathrm{P} 2$ levels for myelin septins will be directly tested by future analysis of the abundance, localization, and extension of myelin septins in PTEN-mutant myelin. CDC42 has been shown to positively regulate the assembly of septin filaments by inhibiting their association with a protein family of septin assembly inhibitors, termed CDC42-effector proteins (cdc42ep) or binder of Rho GTPases (BORG) (Joberty et al., 2001). Thus, the observed myelin pathology upon deletion of PTEN or CDC42 could theoretically be explained by diminished septin filament assembly.

Taken together, the observed loss of myelin integrity in SEPT8-mutants is likely a direct effect of septin loss in adaxonal myelin. Similar structural changes in other myelin mutants such as PTEN and CDC42 might also be related to negative regulation of the septin filament. Alterations in myelin structure of CNP $^{\text {null }}$ and PLP ${ }^{\text {null }}$ mutants were also described (Griffiths et al., 1998, Edgar et al., 2009) and may well be related to a reduced abundance of myelin septins. 
A

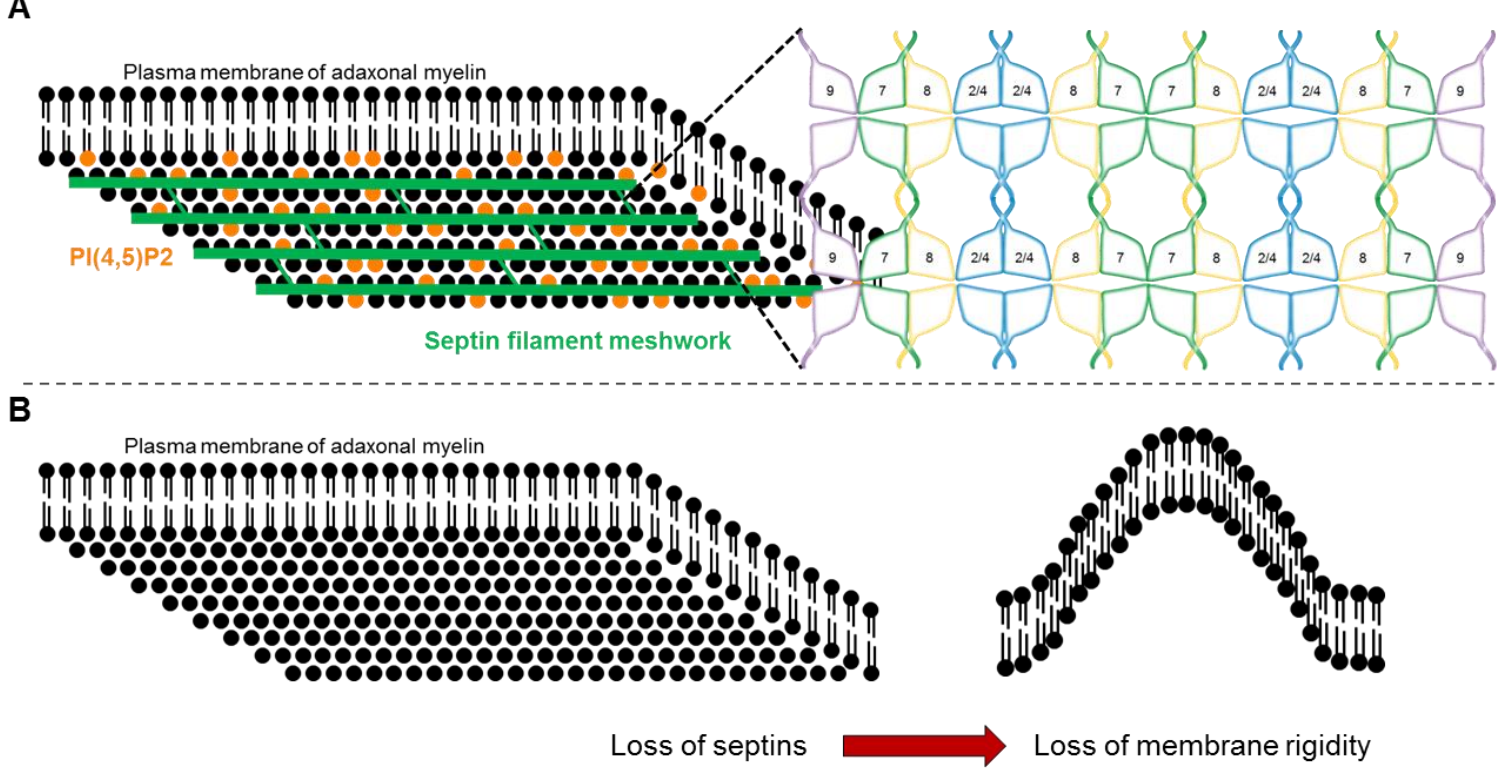

Fig. 21. Model of membrane association by myelin septins. A Septins polymerize dependent on the membrane lipid phosphatidylinositol 4,5-bisphosphate (PI(4,5)P2) (Bertin et al., 2010, model adapted from Gilden et al., 2012). In similarity, myelin septins are hypothesized to elongate along $\mathrm{PI}(4,5) \mathrm{P} 2$-rich domains of the myelin membrane to form a septin filament meshwork. B The septin cytoskeleton has been proposed to enhance membrane rigidity (Gilden et al., 2012). In agreement, myelin outfoldings may reflect diminished membrane rigidity of adaxonal myelin upon an impairment of functional myelin septin filaments.

\subsection{Secondary neuropathology in SEPT8-deficient mice}

PLP and CNP-deficient mice showed a reduction in the abundance of myelin septins (Fig. 4D). In these mice, myelin is formed but axons degenerate (Griffiths et al., 1998, LappeSiefke et al., 2003). We asked the question, if reduced septin abundance in myelin is part of the observed axonal degeneration. The accumulation of APP was used to analyze axonal pathology (Coleman, 2005, Saxena and Caroni, 2007). At the age of half a year, no axonal pathology was observed in SEPT8 conditional mice, as quantified in the fimbria

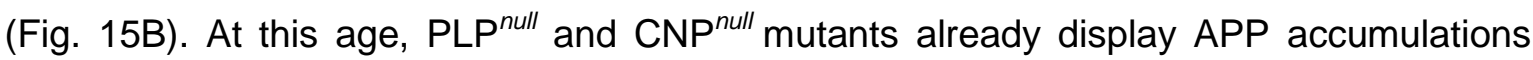
(Griffiths et al., 1998, Lappe-Siefke et al., 2003). Therefore, SEPT8-deficiency does not lead to the same early onset of axonal degeneration as PLP ${ }^{\text {null }}$ and CNP ${ }^{\text {null }}$ mutants.

At the age of one year, conditional SEPT8-mutants, constitutive mutants and the additional control group $C n p 1^{\text {cre/wt }}$ showed equal numbers of APP accumulations whereas wild type controls had none. In Cnp $1^{\text {cre/wt }}$ and in conditional SEPT8 mutants the abundance of CNP in brain lysates and myelin was reduced to about 50\% (Fig. 9B). Recently, this reduction was shown to cause a neurological pathology upon aging (Hagemeyer et al., 2012). In agreement with this report, we also found low numbers of APP accumulations. With that, similar numbers of APP accumulations in conditional SEPT8-mutants could be related to the reduced abundance of CNP (Fig. 15A and B). The 
low numbers of APP accumulations in constitutive SEPT8-mutants might be explained by SEPT8 functions in other cells, e.g. neurons. This could be tested in future experiments by recombining the Sept8-flox allele with a Cre-driver line for recombination in neurons, such as Nex-Cre mice.

We note that the extent of axonal pathology identified in SEPT8-deficient mice is very moderate compared to PLP ${ }^{\text {null }}$ or CNP ${ }^{\text {null }}$ mice. Thus, the reduced abundance of septins and the subsequent emergence of myelin outfoldings do not cause axonal per se. Thus, these two aspects of neuropathology can be uncoupled in SEPT8-mutant mice.

When microglial activation was analyzed, only conditional SEPT8-mutants displayed a significant number of MAC-3 positive microglia upon aging (Fig. 16A and B). By inducing experimental autoimmune encephalomyelitis (EAE), we could show that microglial cells in constitutive SEPT8-mutants are unlikely to be impaired (Fig. 17A). Therefore, we propose that myelin outfoldings in SEPT8-deficient myelin only causes mild inflammation when further triggered, e.g. by a reduction of CNP abundance. Hence, SEPT8 loss and the resulting myelin outfoldings can be viewed as a risk factor for an immune response in the brain.

\subsection{Influence of septin deficiency on the disease course of EAE}

Experimental autoimmune encephalomyelitis (EAE) is an animal model for particular aspects of the pathology in multiple sclerosis (Ransohoff, 2012). It is assumed that inflammation leads to demyelination in multiple sclerosis patients, but the causative agent has not been identified so far. Thus, it has been discussed that myelin damage may trigger the immune response in multiple sclerosis patients (Trapp and Nave, 2008). We have identified that SEPT8-deficiency together with reduced expression of CNP in oligodendrocytes activate microglia in the brain of mice. CNP reduction alone also triggers microglial activation upon aging (Hagemeyer et al., 2012). However, we showed that additional SEPT8 deficiency led to microglia activation to an earlier time point. Hence, we propose that the reduced abundance of CNP might induce microglial activation and that the structural changes affecting myelin as seen in SEPT8-mutant mice enhance the inflammation.

To test this idea, we used the model of EAE to induce inflammation in constitutive SEPT8mutant mice. We ask if myelin outfoldings alter the progression of inflammation. In EAE, an autoimmune response is directed against a myelin protein (Rao and Segal, 2012). Tcells and monocytes invade the CNS and induce an active attack of myelin by macrophages. The strength of inflammation can vary in EAE models and a precise 
experimental set-up is necessary. We used 15-week-old mice, in which myelin outfoldings are already frequent. Indeed, SEPT8-deficient mice showed a trend to an enhanced EAEscore and inflammation 14 days post injection, but not reaching significance. We analyzed 14 days post injection as the peak of inflammation (Markoullis et al., 2012). In our experimental set-up, inflammation was already strong in control animals, which might have been a disadvantage for the detection of an increase in SEPT8-mutant mice. Therefore, a reduction of the administered dosis of pertussis toxin to sub-threshold induction and the analysis at an early post injection date might be more adequate to reveal a significant effect of myelin outfoldings on neuroinflammation.

\subsection{Biology of septins in peripheral myelin}

Oligodendrocytes and Schwann cells form myelin of a different ultrastructure. To approach the septin cytoskeleton also in peripheral nerves, the localization of SEPT7 and SEPT9 was analyzed by teased fiber preparations of sciatic nerves (Fig. 18). Both septins labeled abaxonal cytoplasmic channels of Schwann cells. Hence, septins showed a principally different localization in PNS myelin compared to CNS myelin, and it is thus likely that the exact function of septins is also different.

Our recent proteomic analysis of peripheral myelin revealed SEPT2, SEPT7, SEPT9 and SEPT11 as abundant constituents (Patzig et al., 2011). By analyzing sciatic nerve lysates of wild type mice and constitutive SEPT8-mutants (Fig 19B), we additionally showed that also SEPT8 is expressed by Schwann cells. However, SEPT8-loss did not lead to myelin pathology or a secondary reduction of other septins as in CNS myelin. Interestingly, the abundance of SEPT11, a close homolog of SEPT8, was increased (Fig. 19B). Hence, our results suggest a possible functional redundancy of SEPT8 and SEPT11 in Schwann cells as it was previously predicted for close homologs (Kinoshita, 2003, Buser et al., 2009, Mostowy and Cossart, 2012). This could be tested in future experiments using mouse mutants lacking both, SEPT8 and SEPT11.

The relevance of understanding septin biology in peripheral myelin is obvious when considering hereditary neuralgic amyotrophy (HNA). This neuropathy is associated with duplication or point mutations of the SEPT9-gene leading to episodes of multifocal paresis and sensory loss in patients (van Alfen, 2011). The SEPT9-gene is characterized by the emergence of multiple splice isoforms, which are likely to exert principally different functions in filament polymerization (Peterson and Petty, 2010, Kim et al., 2011). In wild type sciatic nerves of mice, the small $39 \mathrm{kDa}$ isoform was abundant and at least partially present in myelin of Schwann cells (Fig. 18 and Patzig et al., 2011). Deletion or 
overexpression of SEPT9 in mice in various cell types might reveal pathomechanisms relevant in HNA.

\begin{tabular}{|c|c|c|}
\hline & Septins in CNS myelin & Septins in PNS myelin \\
\hline $\begin{array}{c}\text { Predicted } \\
\text { oligomer }\end{array}$ & $9-7-8-2 / 4-2 / 4-8-7-9$ & $9-7-8 / 11-2-2-8 / 11-7-9$ \\
\hline Localization & Adaxonal internodal myelin & $\begin{array}{c}\text { Abaxonal myelin (bands of } \\
\text { Cajal) }\end{array}$ \\
\hline SEPT8 & $\begin{array}{c}\text { Essential for septin oligomer } \\
\text { formation }\end{array}$ & $\begin{array}{c}\text { Redundancy with SEPT11 is } \\
\text { likely }\end{array}$ \\
\hline
\end{tabular}

Fig. 22. A comparison of features of myelin septins in the CNS and the PNS. 


\section{References}

Alberts B (2002) Molecular Biology of the Cell, 4th edition. New York: Garland Science.

Arroyo EJ, Scherer SS (2000) On the molecular architecture of myelinated fibers. Histochem Cell Biol 113:1-18.

Baumann N, Pham-Dinh D (2001) Biology of oligodendrocyte and myelin in the mammalian central nervous system. Physiol Rev 81:871-927.

Bertin A, McMurray MA, Thai L, Garcia G, 3rd, Votin V, Grob P, Allyn T, Thorner J, Nogales E (2010) Phosphatidylinositol-4,5-bisphosphate promotes budding yeast septin filament assembly and organization. J Mol Biol 404:711-731.

Brahic M, Roussarie JP (2009) Axon-myelin interactions during a viral infection of the central nervous system. PLoS Pathog 5:e1000519.

Brinkmann BG, Agarwal A, Sereda MW, Garratt AN, Muller T, Wende H, Stassart RM, Nawaz S, Humml C, Velanac V, Radyushkin K, Goebbels S, Fischer TM, Franklin RJ, Lai C, Ehrenreich H, Birchmeier C, Schwab MH, Nave KA (2008) Neuregulin$1 /$ ErbB signaling serves distinct functions in myelination of the peripheral and central nervous system. Neuron 59:581-595.

Brooks SP, Dunnett SB (2009) Tests to assess motor phenotype in mice: a user's guide. Nat Rev Neurosci 10:519-529.

Buser AM, Erne B, Werner HB, Nave KA, Schaeren-Wiemers N (2009) The septin cytoskeleton in myelinating glia. Mol Cell Neurosci 40:156-166.

Byers B, Goetsch L (1976) A highly ordered ring of membrane-associated filaments in budding yeast. J Cell Biol 69:717-721.

Cao L, Ding X, Yu W, Yang X, Shen S, Yu L (2007) Phylogenetic and evolutionary analysis of the septin protein family in metazoan. FEBS Lett 581:5526-5532.

Chomiak T, Hu B (2009) What is the optimal value of the g-ratio for myelinated fibers in the rat CNS? A theoretical approach. PLoS One 4:e7754.

Coleman M (2005) Axon degeneration mechanisms: commonality amid diversity. Nat Rev Neurosci 6:889-898.

Colman DR, Kreibich G, Frey AB, Sabatini DD (1982) Synthesis and incorporation of myelin polypeptides into CNS myelin. J Cell Biol 95:598-608.

Cuznerml, Hayes GM, Newcombe J, Woodroofe MN (1988) The nature of inflammatory components during demyelination in multiple sclerosis. J Neuroimmunol 20:203209.

de Monasterio-Schrader P, Jahn O, Tenzer S, Wichert SP, Patzig J, Werner HB (2012) Systematic approaches to central nervous system myelin. Cell Mol Life Sci 69:2879-2894.

Dent J, Kato K, Peng XR, Martinez C, Cattaneo M, Poujol C, Nurden P, Nurden A, Trimble WS, Ware J (2002) A prototypic platelet septin and its participation in secretion. Proc Natl Acad Sci U S A 99:3064-3069. 
Dupouey P, Jacque C, Bourre JM, Cesselin F, Privat A, Baumann N (1979) Immunochemical studies of myelin basic protein in shiverer mouse devoid of major dense line of myelin. Neurosci Lett 12:113-118.

Edgar JM, McLaughlin M, Werner HB, McCulloch MC, Barrie JA, Brown A, Faichney AB, Snaidero N, Nave KA, Griffiths IR (2009) Early ultrastructural defects of axons and axon-glia junctions in mice lacking expression of Cnp1. Glia 57:1815-1824.

Edgar JM, McLaughlin M, Yool D, Zhang SC, Fowler JH, Montague P, Barrie JA, McCulloch MC, Duncan ID, Garbern J, Nave KA, Griffiths IR (2004) Oligodendroglial modulation of fast axonal transport in a mouse model of hereditary spastic paraplegia. J Cell Biol 166:121-131.

Einheber S, Zanazzi G, Ching W, Scherer S, Milner TA, Peles E, Salzer JL (1997) The axonal membrane protein Caspr, a homologue of neurexin IV, is a component of the septate-like paranodal junctions that assemble during myelination. J Cell Biol 139:1495-1506.

Farley FW, Soriano P, Steffen LS, Dymecki SM (2000) Widespread recombinase expression using FLPeR (flipper) mice. Genesis 28:106-110.

Fewou SN, Fernandes A, Stockdale K, Francone VP, Dupree JL, Rosenbluth J, Pfeiffer SE, Bansal R (2010) Myelin protein composition is altered in mice lacking either sulfated or both sulfated and non-sulfated galactolipids. J Neurochem 112:599610.

Fitzner D, Schnaars M, van Rossum D, Krishnamoorthy G, Dibaj P, Bakhti M, Regen T, Hanisch UK, SimonsM (2011) Selective transfer of exosomes from oligodendrocytes to microglia by macropinocytosis. J Cell Sci 124:447-458.

Fuchtbauer A, Lassen LB, Jensen AB, Howard J, Quiroga Ade S, Warming S, Sorensen $A B$, Pedersen FS, Fuchtbauer EM (2011) Septin9 is involved in septin filament formation and cellular stability. Biol Chem 392:769-777.

Gallyas F (1979) Silver staining of myelin by means of physical development. Neurol Res 1:203-209.

Gilden J, Krummel MF (2010) Control of cortical rigidity by the cytoskeleton: emerging roles for septins. Cytoskeleton (Hoboken) 67:477-486.

Gilden JK, Peck S, M. Chen Y-C, Krummel MF (2012) The septin cytoskeleton facilitates membrane retraction during motility and blebbing. The Journal of Cell Biology 196:103-114.

Giulian D, Baker TJ (1986) Characterization of ameboid microglia isolated from developing mammalian brain. J Neurosci 6:2163-2178.

Goebbels S, Oltrogge JH, Kemper R, Heilmann I, Bormuth I, Wolfer S, Wichert SP, Mobius W, Liu X, Lappe-Siefke C, Rossner MJ, Groszer M, Suter U, Frahm J, Boretius S, Nave KA (2010) Elevated phosphatidylinositol 3,4,5-trisphosphate in glia triggers cell-autonomous membrane wrapping and myelination. J Neurosci 30:8953-8964.

Goring DR, Rossant J, Clapoff S, Breitmanml, Tsui LC (1987) In situ detection of betagalactosidase in lenses of transgenic mice with a gamma-crystallin/lacZ gene. Science 235:456-458. 
Griffiths I, Klugmann M, Anderson T, Yool D, Thomson C, Schwab MH, Schneider A, Zimmermann F, McCulloch M, Nadon N, Nave KA (1998) Axonal swellings and degeneration in mice lacking the major proteolipid of myelin. Science 280:16101613.

Haarer BK, Pringle JR (1987) Immunofluorescence localization of the Saccharomyces cerevisiae CDC12 gene product to the vicinity of the 10-nm filaments in the mother-bud neck. Mol Cell Biol 7:3678-3687.

Hagemeyer N, Goebbels S, Papiol S, Kastner A, Hofer S, Begemann M, Gerwig UC, Boretius S, Wieser GL, Ronnenberg A, Gurvich A, Heckers SH, Frahm J, Nave $\mathrm{KA}$, Ehrenreich $\mathrm{H}$ (2012) A myelin gene causative of a catatonia-depression syndrome upon aging. EMBO Mol Med 4:528-539.

Hall PA, Bruford E, Russell SEH, Macara IG, Pringle JR (2008) Appendix B: Mammalian Septin Nomenclature. In: The Septins, pp 351-354: John Wiley \& Sons, Ltd.

Hall PA, Russell SE (2004) The pathobiology of the septin gene family. J Pathol 204:489505.

Hall PA, Russell SE (2012) Mammalian septins: dynamic heteromers with roles in cellular morphogenesis and compartmentalization. J Pathol 226:287-299.

Hartwell LH (1971) Genetic control of the cell division cycle in yeast. IV. Genes controlling bud emergence and cytokinesis. Exp Cell Res 69:265-276.

Hildebrand C, Hahn R (1978) Relation between myelin sheath thickness and axon size in spinal cord white matter of some vertebrate species. J Neurol Sci 38:421-434.

Ho MK, Springer TA (1983) Tissue distribution, structural characterization, and biosynthesis of Mac-3, a macrophage surface glycoprotein exhibiting molecular weight heterogeneity. J Biol Chem 258:636-642.

Holzenberger M, Lenzner C, Leneuve P, Zaoui R, Hamard G, Vaulont S, Bouc YL (2000) Cre-mediated germline mosaicism: a method allowing rapid generation of several alleles of a target gene. Nucleic Acids Res 28:E92.

Hu Q, Milenkovic L, Jin H, Scott M, Nachury M, Spiliotis E, Nelson W (2010) A septin diffusion barrier at the base of the primary cilium maintains ciliary membrane protein distribution. Science 329:436-439.

Ishii A, Dutta R, Wark GM, Hwang SI, Han DK, Trapp BD, Pfeiffer SE, Bansal R (2009) Human myelin proteome and comparative analysis with mouse myelin. Proc Natl Acad Sci U S A 106:14605-14610.

Jahn O, Tenzer S, Bartsch N, Patzig J, Werner HB (2013) Myelin proteome analysis: methods and implications for the myelin cytoskeleton. In: The Cytoskeleton: Imaging, Isolation, and Interaction. Neuromethods 79:335-354. Springer, ed: Dermietzel R.

Jahn O, Tenzer S, Werner HB (2009) Myelin proteomics: molecular anatomy of an insulating sheath. Mol Neurobiol 40:55-72.

Jessen KR, Mirsky R (2005) The origin and development of glial cells in peripheral nerves. Nat Rev Neurosci 6:671-682. 
Joberty G, Perlungher RR, Sheffield PJ, Kinoshita M, Noda M, Haystead T, Macara IG (2001) Borg proteins control septin organization and are negatively regulated by Cdc42. Nat Cell Biol 3:861-866.

Kettenmann H, Ransom BR (2005) Neuroglia: Oxford University Press.

Kim MS, Froese CD, Estey MP, Trimble WS (2011) SEPT9 occupies the terminal positions in septin octamers and mediates polymerization-dependent functions in abscission. J Cell Biol 195:815-826.

KinoshitaM (2003) Assembly of Mammalian Septins. Journal of Biochemistry 134:491496.

Kinoshita M, Field CM, Coughlinml, Straight AF, Mitchison TJ (2002) Self- and actintemplated assembly of Mammalian septins. Dev Cell 3:791-802.

Kissel H, Georgescu MM, Larisch S, Manova K, Hunnicutt GR, Steller H (2005) The Sept4 septin locus is required for sperm terminal differentiation in mice. Dev Cell 8:353364.

Klugmann M, Schwab MH, Puhlhofer A, Schneider A, Zimmermann F, Griffiths IR, Nave KA (1997) Assembly of CNS myelin in the absence of proteolipid protein. Neuron 18:59-70.

Kramer-Albers EM, Bretz N, Tenzer S, Winterstein C, Mobius W, Berger H, Nave KA, Schild H, Trotter J (2007) Oligodendrocytes secrete exosomes containing major myelin and stress-protective proteins: Trophic support for axons? Proteomics Clin Appl 1:1446-1461.

Kremer BE, Adang LA, Macara IG (2007) Septins regulate actin organization and cellcycle arrest through nuclear accumulation of NCK mediated by SOCS7. Cell 130:837-850.

Kwitny S, Klaus AV, Hunnicutt GR (2010) The annulus of the mouse sperm tail is required to establish a membrane diffusion barrier that is engaged during the late steps of spermiogenesis. Biol Reprod 82:669-678.

Laemmli UK (1970) Cleavage of structural proteins during the assembly of the head of bacteriophage T4. Nature 227:680-685.

Lambertsen KL, Clausen BH, Babcock AA, Gregersen R, Fenger C, Nielsen $\mathrm{HH}$, Haugaard LS, Wirenfeldt M, Nielsen M, Dagnaes-Hansen F, Bluethmann $H$, Faergeman NJ, Meldgaard M, Deierborg T, Finsen B (2009) Microglia protect neurons against ischemia by synthesis of tumor necrosis factor. $\mathrm{J}$ Neurosci 29:1319-1330.

Lappe-Siefke C, Goebbels S, Gravel M, Nicksch E, Lee J, Braun PE, Griffiths IR, Nave KA (2003) Disruption of Cnp1 uncouples oligodendroglial functions in axonal support and myelination. Nat Genet 33:366-374.

Larocca JN, Norton WT (2007) Isolation of myelin. Curr Protoc Cell Biol Chapter 3:Unit3 25.

Lee J, Gravel M, Zhang R, Thibault P, Braun PE (2005) Process outgrowth in oligodendrocytes is mediated by CNP, a novel microtubule assembly myelin protein. J Cell Biol 170:661-673. 
Liou W, Geuze HJ, Slot JW (1996) Improving structural integrity of cryosections for immunogold labeling. Histochem Cell Biol 106:41-58.

Liu J, Fairn GD, Ceccarelli DF, Sicheri F, Wilde A (2012) Cleavage Furrow Organization Requires PIP(2)-Mediated Recruitment of Anillin. Curr Biol 22:64-69.

Low C, Macara IG (2006) Structural analysis of septin 2, 6, and 7 complexes. J Biol Chem 281:30697-30706.

Lowry OH, Rosebrough NJ, Farr AL, Randall RJ (1951) Protein measurement with the Folin phenol reagent. J Biol Chem 193:265-275.

Macara IG, Baldarelli R, Field CM, Glotzer M, Hayashi Y, Hsu SC, Kennedy MB, Kinoshita M, Longtine M, Low C, Maltais LJ, McKenzie L, Mitchison TJ, Nishikawa T, Noda M, Petty EM, Peifer M, Pringle JR, Robinson PJ, Roth D, Russell SE, Stuhlmann H, Tanaka M, Tanaka T, Trimble WS, Ware J, Zeleznik-Le NJ, Zieger B (2002) Mammalian septins nomenclature. Mol Biol Cell 13:4111-4113.

Maddox AS, Lewellyn L, Desai A, Oegema K (2007) Anillin and the septins promote asymmetric ingression of the cytokinetic furrow. Dev Cell 12:827-835.

Markoullis K, Sargiannidou I, Gardner C, Hadjisavvas A, Reynolds R, Kleopa KA (2012) Disruption of oligodendrocyte gap junctions in experimental autoimmune encephalomyelitis. Glia 60:1053-1066.

Martini R, Mohajeri MH, Kasper S, Giese KP, SchachnerM (1995) Mice doubly deficient in the genes for $\mathrm{P} 0$ and myelin basic protein show that both proteins contribute to the formation of the major dense line in peripheral nerve myelin. J Neurosci 15:44884495.

Mendoza M, Hyman AA, GlotzerM (2002) GTP binding induces filament assembly of a recombinant septin. Curr Biol 12:1858-1863.

Michailov GV, Sereda MW, Brinkmann BG, Fischer TM, Haug B, Birchmeier C, Role L, Lai C, Schwab MH, Nave KA (2004) Axonal neuregulin-1 regulates myelin sheath thickness. Science 304:700-703.

Mobius W, Cooper B, Kaufmann WA, Imig C, Ruhwedel T, Snaidero N, Saab AS, Varoqueaux $F$ (2010) Electron microscopy of the mouse central nervous system. Methods Cell Biol 96:475-512.

Mobius W, Patzig J, Nave KA, Werner HB (2008) Phylogeny of proteolipid proteins: divergence, constraints, and the evolution of novel functions in myelination and neuroprotection. Neuron Glia Biol 4:111-127.

Mosley K, Cuznerml (1996) Receptor-mediated phagocytosis of myelin by macrophages and microglia: effect of opsonization and receptor blocking agents. Neurochem Res 21:481-487.

Mostowy S, Cossart P (2012) Septins: the fourth component of the cytoskeleton. Nat Rev Mol Cell Biol 13:183-194.

Mullis K, Faloona F, Scharf S, Saiki R, Horn G, Erlich H (1986) Specific enzymatic amplification of DNA in vitro: the polymerase chain reaction. Cold Spring Harb Symp Quant Biol 51 Pt 1:263-273. 
Nagata K, Asano T, Nozawa Y, InagakiM (2004) Biochemical and cell biological analyses of a mammalian septin complex, Sept7/9b/11. J Biol Chem 279:55895-55904.

Nave KA (2010) Myelination and support of axonal integrity by glia. Nature 468:244-252.

Nimmerjahn A, Kirchhoff F, Helmchen F (2005) Resting microglial cells are highly dynamic surveillants of brain parenchyma in vivo. Science 308:1314-1318.

Norton WT, Poduslo SE (1973) Myelination in rat brain: method of myelin isolation. J Neurochem 21:749-757.

Oegema K, Savoian MS, Mitchison TJ, Field CM (2000) Functional analysis of a human homologue of the Drosophila actin binding protein anillin suggests a role in cytokinesis. J Cell Biol 150:539-552.

Oh Y, Bi E (2011) Septin structure and function in yeast and beyond. Trends Cell Biol 21:141-148.

Pan F, Malmberg RL, MomanyM (2007) Analysis of septins across kingdoms reveals orthology and new motifs. BMC Evol Biol 7:103.

Patzig J, Jahn O, Tenzer S, Wichert SP, de Monasterio-Schrader P, Rosfa S, Kuharev J, Yan K, Bormuth I, Bremer J, Aguzzi A, Orfaniotou F, Hesse D, Schwab MH, Mobius W, Nave KA, Werner HB (2011) Quantitative and integrative proteome analysis of peripheral nerve myelin identifies novel myelin proteins and candidate neuropathy loci. J Neurosci 31:16369-16386.

Peng XR, Jia Z, Zhang Y, Ware J, Trimble WS (2002) The septin CDCrel-1 is dispensable for normal development and neurotransmitter release. Mol Cell Biol 22:378-387.

Peterson EA, Petty EM (2010) Conquering the complex world of human septins: implications for health and disease. Clin Genet 77:511-524.

Peterson GL (1979) Review of the Folin phenol protein quantitation method of Lowry, Rosebrough, Farr and Randall. Anal Biochem 100:201-220.

Pinteaux-Jones F, Sevastou IG, Fry VA, Heales S, Baker D, Pocock JM (2008) Myelininduced microglial neurotoxicity can be controlled by microglial metabotropic glutamate receptors. J Neurochem 106:442-454.

Poliak S, Peles E (2003) The local differentiation of myelinated axons at nodes of Ranvier. Nat Rev Neurosci 4:968-980.

Ransohoff RM (2012) Animal models of multiple sclerosis: the good, the bad and the bottom line. Nat Neurosci 15:1074-1077.

Ransohoff RM, Brown MA (2012) Innate immunity in the central nervous system. J Clin Invest 122:1164-1171.

Ransohoff RM, Cardona AE (2010) The myeloid cells of the central nervous system parenchyma. Nature 468:253-262.

Rao P, Segal BM (2012) Experimental autoimmune encephalomyelitis. Methods Mol Biol 900:363-380.

Rasband MN (2011) Composition, assembly, and maintenance of excitable membrane domains in myelinated axons. Semin Cell Dev Biol 22:178-184. 
Rasband MN, Tayler J, Kaga Y, Yang Y, Lappe-Siefke C, Nave KA, Bansal R (2005) CNP is required for maintenance of axon-glia interactions at nodes of Ranvier in the CNS. Glia 50:86-90.

Richardson KC, Jarett L, Finke EH (1960) Embedding in epoxy resins for ultrathin sectioning in electron microscopy. Stain Technol 35:313-323.

Richter-Landsberg C (2001) Organization and functional roles of the cytoskeleton in oligodendrocytes. Microsc Res Tech 52:628-636.

Rinholm JE, Hamilton NB, Kessaris N, Richardson WD, Bergersen LH, Attwell D (2011) Regulation of oligodendrocyte development and myelination by glucose and lactate. J Neurosci 31:538-548.

Rivest S (2009) Regulation of innate immune responses in the brain. Nat Rev Immunol 9:429-439.

Rosenbluth J, Nave KA, Mierzwa A, Schiff R (2006) Subtle myelin defects in PLP-null mice. Glia 54:172-182.

Roth J, Bendayan M, Orci L (1978) Ultrastructural localization of intracellular antigens by the use of protein A-gold complex. J Histochem Cytochem 26:1074-1081.

Saiki RK, Gelfand DH, Stoffel S, Scharf SJ, Higuchi R, Horn GT, Mullis KB, Erlich HA (1988) Primer-directed enzymatic amplification of DNA with a thermostable DNA polymerase. Science 239:487-491.

Sanes JR (1994) Lineage tracing. The laatest in lineaage. Curr Biol 4:1162-1164.

Saxena S, Caroni P (2007) Mechanisms of axon degeneration: from development to disease. Prog Neurobiol 83:174-191.

Sellin ME, Sandblad L, Stenmark S, GullbergM (2011) Deciphering the rules governing assembly order of mammalian septin complexes. Mol Biol Cell 22:3152-3164.

Sheffield PJ, Oliver CJ, Kremer BE, Sheng S, Shao Z, Macara IG (2003) Borg/septin interactions and the assembly of mammalian septin heterodimers, trimers, and filaments. J Biol Chem 278:3483-3488.

Sirajuddin M, Farkasovsky M, Hauer F, Kuhlmann D, Macara IG, Weyand M, Stark H, Wittinghofer A (2007) Structural insight into filament formation by mammalian septins. Nature 449:311-315.

Slot JW, Geuze HJ (1985) A new method of preparing gold probes for multiple-labeling cytochemistry. Eur J Cell Biol 38:87-93.

Spiliotis ET, Gladfelter AS (2012) Spatial guidance of cell asymmetry: septin GTPases show the way. Traffic 13:195-203.

Sprinkle TJ (1989) 2',3'-cyclic nucleotide 3'-phosphodiesterase, an oligodendrocyteSchwann cell and myelin-associated enzyme of the nervous system. Crit Rev Neurobiol 4:235-301.

Tada T, Simonetta A, Batterton M, Kinoshita M, Edbauer D, ShengM (2007) Role of Septin cytoskeleton in spine morphogenesis and dendrite development in neurons. Curr Biol 17:1752-1758. 
Tanaka-Takiguchi Y, Kinoshita M, Takiguchi K (2009) Septin-mediated uniform bracing of phospholipid membranes. Curr Biol 19:140-145.

Thurnherr T, Benninger $\mathrm{Y}, \mathrm{Wu} \mathrm{X}$, Chrostek A, Krause SM, Nave KA, Franklin RJ, Brakebusch C, Suter U, Relvas JB (2006) Cdc42 and Rac1 signaling are both required for and act synergistically in the correct formation of myelin sheaths in the CNS. J Neurosci 26:10110-10119.

Tooley AJ, Gilden J, Jacobelli J, Beemiller P, Trimble WS, Kinoshita M, Krummel MF (2009) Amoeboid T lymphocytes require the septin cytoskeleton for cortical integrity and persistent motility. Nat Cell Biol 11:17-26.

Towbin H, Staehelin T, Gordon J (1979) Electrophoretic transfer of proteins from polyacrylamide gels to nitrocellulose sheets: procedure and some applications. Proc Natl Acad Sci U S A 76:4350-4354.

Trapp BD, Andrews SB, Cootauco C, Quarles R (1989) The myelin-associated glycoprotein is enriched in multivesicular bodies and periaxonal membranes of actively myelinating oligodendrocytes. J Cell Biol 109:2417-2426.

Trapp BD, Nave KA (2008) Multiple sclerosis: an immune or neurodegenerative disorder? Annu Rev Neurosci 31:247-269.

Trapp BD, Quarles RH (1982) Presence of the myelin-associated glycoprotein correlates with alterations in the periodicity of peripheral myelin. J Cell Biol 92:877-882.

Tsang CW, Estey MP, DiCiccio JE, Xie H, Patterson D, Trimble WS (2011) Characterization of presynaptic septin complexes in mammalian hippocampal neurons. Biol Chem 392:739-749.

van Alfen N (2011) Clinical and pathophysiological concepts of neuralgic amyotrophy. Nat Rev Neurol 7:315-322.

Wang H, Kunkel DD, Martin TM, Schwartzkroin PA, Tempel BL (1993) Heteromultimeric $\mathrm{K}+$ channels in terminal and juxtaparanodal regions of neurons. Nature 365:75-79.

Werner HB, Kramer-Albers EM, Strenzke N, Saher G, Tenzer S, Ohno-Iwashita Y, De Monasterio-Schrader P, Mobius W, Moser T, Griffiths IR, Nave KA (2013) A critical role for the cholesterol-associated proteolipids PLP and M6B in myelination of the central nervous system. Glia 61:567-586.

Werner HB, Kuhlmann K, Shen S, Uecker M, Schardt A, Dimova K, Orfaniotou F, Dhaunchak A, Brinkmann BG, Mobius W, Guarente L, Casaccia-Bonnefil P, Jahn O, Nave KA (2007) Proteolipid protein is required for transport of sirtuin 2 into CNS myelin. J Neurosci 27:7717-7730.

Wilson R, Brophy PJ (1989) Role for the oligodendrocyte cytoskeleton in myelination. J Neurosci Res 22:439-448.

Xie Y, Vessey JP, Konecna A, Dahm R, Macchi P, Kiebler MA (2007) The GTP-binding protein Septin 7 is critical for dendrite branching and dendritic-spine morphology. Curr Biol 17:1746-1751.

Yang YM, Fedchyshyn MJ, Grande G, Aitoubah J, Tsang CW, Xie H, Ackerley CA, Trimble WS, Wang LY (2010) Septins regulate developmental switching from 
microdomain to nanodomain coupling of $\mathrm{Ca}(2+)$ influx to neurotransmitter release at a central synapse. Neuron 67:100-115.

Yong VW, Rivest S (2009) Taking advantage of the systemic immune system to cure brain diseases. Neuron 64:55-60.

Yool DA, Klugmann M, McLaughlin M, Vouyiouklis DA, Dimou L, Barrie JA, McCulloch MC, Nave KA, Griffiths IR (2001) Myelin proteolipid proteins promote the interaction of oligodendrocytes and axons. J Neurosci Res 63:151-164.

Zheng $\mathrm{H}$, Koo EH (2006) The amyloid precursor protein: beyond amyloid. Mol Neurodegener 1:5.

Zonta B, Tait S, Melrose S, Anderson H, Harroch S, Higginson J, Sherman DL, Brophy PJ (2008) Glial and neuronal isoforms of Neurofascin have distinct roles in the assembly of nodes of Ranvier in the central nervous system. J Cell Biol 181:11691177. 


\section{Curriculum vitae}

Surname: Patzig

First Name: Julia

Date of birth: 21.08 .1983

Place of birth: Riesa

Nationality: German

Home address: Springstraße 5

37077 Göttingen, Germany

Work address: MPI of Experimental Medicine

Department of Neurogenetics

Hermann-Rein Str. 3

37075, Göttingen, Germany.

Tel. +49 551 3899-739

E-mail: Patzig@em.mpg.de

\section{Education:}

2009 - present Graduate student at the Max-Planck-Institute of Experimental Medicine Department of Neurogenetics (Göttingen)

Thesis: "Identification of a septin filament required for CNS myelin integrity", Fellow of the GGNB PhD program Molecular Physiology of the Brain (University of Göttingen)

2008 Diploma of biology from the University of Göttingen

2003 - 2008 Academic study of biology University Göttingen

2002 Allgemeine Hochschulreife (Abitur) in Pirna, Germany

Research experience:

2009-Present Research associate at the Max-Planck-Institute of Experimental Medicine Department of Neurogenetics (Göttingen)

Focus: Proteomic analysis of peripheral and central nervous system myelin. Analysis of the requirement of septin filaments in myelinating glia.

2008 Diploma thesis "Funktionsanalyse der Myelinproteine Proteolipid Protein und Myelinprotein Zero in vivo." 
Max-Planck-Institute of Experimental Medicine (Göttingen)

Department of Neurogenetics

Languages: German: native

English: fluent

\section{Poster presentations:}

Patzig J, Möbius W, Sereda MW, Nave KA, Martini R, and Werner HB. Myelin proteolipid protein modulates loss of peripheral axons and viability of a mouse model of Déjérine-Sottas syndrome caused by a protein zero mutation. Glia in Health and Disease, Cold Spring Harbor, NY USA 2012

Patzig J, Möbius W, Göbbels S, Nave KA, and Werner HB. A septin filament stabilizes central nervous system myelin. Glia in Health and Disease, Cold Spring Harbor, NY USA 2012

Patzig $\mathbf{J}$ and Werner HB. A septin filament stabilizes central nervous system myelin. EMBO Workshop, Function and structure of septins, filament-forming GTPbinding proteins. St. Goar Germany 2011

Patzig J, Möbius W, Sereda MW, Nave KA, Martini R, and Werner HB. Proteolipid protein alleviates the neurological phenotype in a mouse model of Déjérine-Sottas syndrome caused by a protein zero mutation. $9^{\text {th }}$ European Meeting on Glial Cells in Health and Disease. Paris, France 2009 


\section{Publications:}

\section{Peer-reviewed}

Möbius W, Patzig J, Nave KA, Werner HB (2008). Phylogeny of proteolipid proteins: divergence, constraints, and the evolution of novel functions in myelination and Neuroprotection. Neuron Glia Biol. 4, 111-127

Patzig J, Jahn O, Tenzer S, Wichert SP, de Monasterio-Schrader P, Rosfa S, Kuharev J, Yan K, Bormuth I, Bremer J, Aguzzi A, Orfaniotou F, Hesse D, Schwab $\mathrm{MH}$, Möbius W, Nave KA, Werner HB (2011). Quantitative and integrative proteome analysis of peripheral nerve myelin identifies novel myelin proteins and candidate neuropathy loci. J Neurosci. 31, 16369-16386

de Monasterio-Schrader P, Jahn O, Tenzer S, Wichert SP, Patzig J, Werner HB (2012). Systematic approaches to central nervous system myelin. Cell Mol Life Sci. 69, 2879-2894

\section{Non-peer-reviewed}

Jahn O, Tenzer S, Bartsch N, Patzig J, Werner HB (2013). Myelin proteome analysis: methods and implications for the myelin cytoskeleton. In: The Cytoskeleton: Imaging, Isolation, and Interaction. Neuromethods 79:335-354. Springer, ed: Dermietzel R. 